\title{
Potent Cyclic Peptide Inhibitors of FXIla Discovered by mRNA Display with Genetic Code Reprogramming
}

Citation for published version (APA):

Ford, D. J., Duggan, N. M., Fry, S. E., Ripoll-Rozada, J., Agten, S. M., Liu, W., Corcilius, L., Hackeng, T. M., van Oerle, R., Spronk, H. M. H., Ashhurst, A. S., Mini Sasi, V., Kaczmarski, J. A., Jackson, C. J., Pereira, P. J. B., Passioura, T., Suga, H., \& Payne, R. J. (2021). Potent Cyclic Peptide Inhibitors of FXIla Discovered by mRNA Display with Genetic Code Reprogramming. Journal of Medicinal Chemistry, 64(11), 7853-7876. https://doi.org/10.1021/acs.jmedchem.1c00651

Document status and date:

Published: 10/06/2021

DOI:

10.1021/acs.jmedchem.1c00651

Document Version:

Publisher's PDF, also known as Version of record

Document license:

Taverne

Please check the document version of this publication:

- A submitted manuscript is the version of the article upon submission and before peer-review. There can be important differences between the submitted version and the official published version of record.

People interested in the research are advised to contact the author for the final version of the publication, or visit the DOI to the publisher's website.

- The final author version and the galley proof are versions of the publication after peer review.

- The final published version features the final layout of the paper including the volume, issue and page numbers.

Link to publication

\footnotetext{
General rights rights.

- You may freely distribute the URL identifying the publication in the public portal. please follow below link for the End User Agreement:

www.umlib.nl/taverne-license

Take down policy

If you believe that this document breaches copyright please contact us at:

repository@maastrichtuniversity.nl

providing details and we will investigate your claim.
}

Copyright and moral rights for the publications made accessible in the public portal are retained by the authors and/or other copyright owners and it is a condition of accessing publications that users recognise and abide by the legal requirements associated with these

- Users may download and print one copy of any publication from the public portal for the purpose of private study or research.

- You may not further distribute the material or use it for any profit-making activity or commercial gain

If the publication is distributed under the terms of Article $25 \mathrm{fa}$ of the Dutch Copyright Act, indicated by the "Taverne" license above, 


\title{
Potent Cyclic Peptide Inhibitors of FXIla Discovered by mRNA Display with Genetic Code Reprogramming
}

\author{
Daniel J. Ford, Nisharnthi M. Duggan, Sarah E. Fry, Jorge Ripoll-Rozada, Stijn M. Agten, Wenyu Liu, \\ Leo Corcilius, Tilman M. Hackeng, Rene van Oerle, Henri M. H. Spronk, Anneliese S. Ashhurst, \\ Vishnu Mini Sasi, Joe A. Kaczmarski, Colin J. Jackson, Pedro José Barbosa Pereira, Toby Passioura, \\ Hiroaki Suga, and Richard J. Payne*
}

Cite This: J. Med. Chem. 2021, 64, 7853-7876

Read Online

ACCESS | Lill Metrics \& More | 期 Article Recommendations

Supporting Information

ABSTRACT: The contact system comprises a series of serine proteases that mediate procoagulant and proinflammatory activities via the intrinsic pathway of coagulation and the kallikrein-kinin system, respectively. Inhibition of Factor XIIa (FXIIa), an initiator of the contact system, has been demonstrated to lead to thromboprotection and anti-inflammatory effects in animal models and serves as a potentially safer target for the development of antithrombotics. Herein, we describe the use of the Randomised Nonstandard Peptide Integrated Discovery (RaPID) mRNA display technology to identify a series of potent and selective cyclic peptide inhibitors of FXIIa. Cyclic peptides were evaluated in vitro, and three lead compounds exhibited significant prolongation of aPTT, a reduction in thrombin generation, and an inhibition of

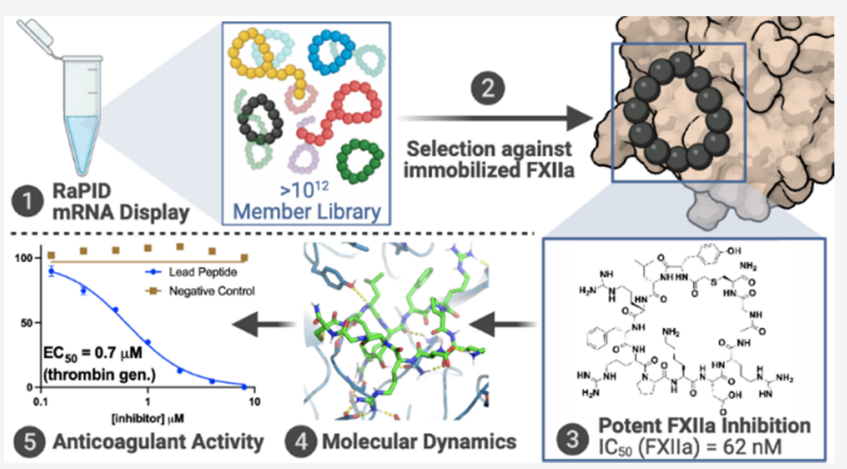
bradykinin formation. We also describe our efforts to identify the critical residues for binding FXIIa through alanine scanning, analogue generation, and via in silico methods to predict the binding mode of our lead cyclic peptide inhibitors.

\section{INTRODUCTION}

Hageman factor (FXII) is an $80 \mathrm{kDa}$ protein that is primarily expressed by liver hepatocytes, circulating as a catalytically inactive zymogen throughout the vasculature, where it orchestrates highly complex and sophisticated coagulation and inflammation events. Intrinsic coagulation is initiated through FXII autoactivation, which occurs when the protein binds to anionic artificial or biological surfaces. ${ }^{1}$ Once activated, $\alpha$ FXIIa initiates a cascade of serine proteases via its substrate, Factor XI (FXI), which ultimately leads to the cleavage of soluble fibrinogen to insoluble fibrin. This insoluble fibrin acts to stabilize the hemostatic plug (blood clot) and protects from blood loss at the site of vascular breach, ultimately fulfilling a critical role in hemostasis. ${ }^{2,3}$ The intrinsic coagulation pathway is also initiated upon proteolytic cleavage of FXII at Arg353-Val354 by plasma kallikrein (PK), whereby the zymogen is converted to the catalytically active protease $\alpha$ FXIIa. From here, $\alpha$ FXIIa activates the kallikrein-kinin system $(\mathrm{KKS})^{4,5}$ by cleaving preplasma kallikrein (PPK) to produce plasma kallikrein (PK), which reciprocally activates FXII, thus generating a positive feedback loop of FXII activation (Figure 1). The end-product of the KKS, bradykinin (BK), is subsequently liberated from high-molecular-weight kininogen upon cleavage by $\mathrm{PK}$, which goes on to fulfill a multitude of downstream physiological processes. Upon BK binding, the $B_{1}$ and $B_{2}$ receptors $\left(B_{1} R\right.$ and $\left.B_{2} R\right)$ induce proinflammatory mechanisms, including increased vascular permeability, vasodilation, mast cell degranulation, and neutrophil chemotaxis. ${ }^{6,7}$ Furthermore, $\alpha$ FXIIa can undergo further proteolytic cleavage to form a $30 \mathrm{kDa}$ protein, $\beta$ FXIIa, that retains its activity against $\mathrm{PK}$ but which is incapable of binding negatively charged surfaces. The $\beta$ FXIIa subunit also has crucial biological roles in vivo, whereby it modulates the complement system through the ubiquitous receptors $\mathrm{C} 1 \mathrm{q}$ and $\mathrm{gC} 1 \mathrm{qR} / \mathrm{p} 33$ and, therefore, connects both the complement and contact systems ${ }^{8}$ (Figure 1).

Importantly, in stark contrast to deficiencies in tissue factor (TF) and factors VII, VIII (Hemophilia A), or IX (Hemophilia B), individuals with severe deficiencies of FXII do not suffer from spontaneous or injury-related bleeding. ${ }^{1}$ Indeed, $\mathrm{FXII}^{-/-}$deficient mice are protected from venous thrombosis, and therapeutic targeting of FXIIa with the experimental antibody

Received: April 9, 2021

Published: May 28, 2021 


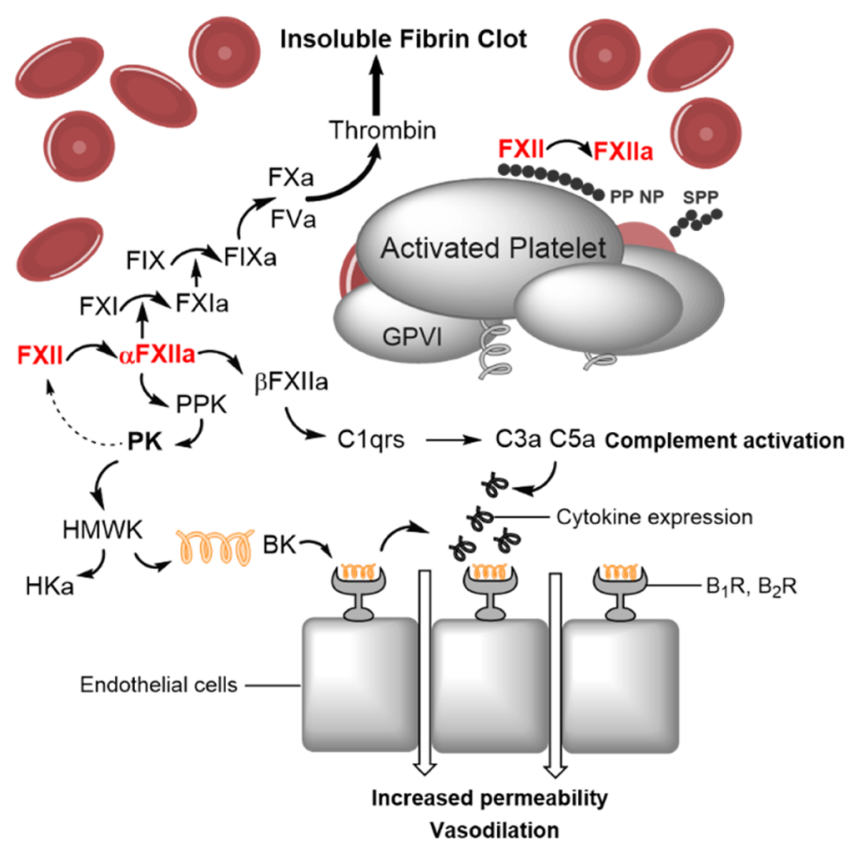

Figure 1. FXII signaling pathway. FXII zymogen autoactivates to the active serine protease $\alpha$ FXIIa upon binding of negatively charged surfaces, such as platelet and bacterial-derived polyphosphates, artificial surgical implants, neutrophil extracellular traps, and viral DNA. Autoactivation initiates intrinsic coagulation through cleavage of FXI ultimately leading to fibrin deposition. $\alpha$ FXIIa also initiates the kallikrein-kinin system (KKS) through cleavage of preplasma kallikrein to kallikrein, which liberates the proinflammatory peptide BK from high-molecular-weight kininogen. Kallikrein reciprocally activates FXII, leading to a positive feedback loop of FXII activation. $\alpha$ FXIIa undergoes further proteolysis by kallikrein to $\beta$ FXIIa, which retains its activity against preplasma kallikrein and also activates the complement system, contributing to further inflammatory responses. SPP, short polyphosphate; PP NP, polyphosphate nanoparticle; HMWK, high-molecular-weight kininogen; HKa, cleaved HMWK; BK, bradykinin; C3a, complement component 3 subunit a; C5a, complement component 5 subunit a; GPVI, glycoprotein 6; C1qrs, complement component 1 subunit $\mathrm{q}$, subunit $\mathrm{r}$, subunit $\mathrm{s}$.

3F7 has demonstrated thrombo-protection in models of extracorporeal circulation, without imparting a bleeding phenotype. ${ }^{9}$ Similarly, FXIIa inhibition reduces thrombus formation in nonhuman primate models of thrombosis without impairing the hemostatic capacity. ${ }^{10,11}$

The attractiveness of both the $\alpha$ and $\beta$ forms of FXIIa as safe and effective targets for a range of thrombosis and inflammatory indications has led to the development of several classes of inhibitors to date. This includes small-molecule, peptide, and protein inhibitors, as well as anti-FXII/FXIIa antibodies. ${ }^{9,12-21}$ Despite showing promise in animal models of thrombosis and inflammation, the only inhibitor of FXIIa used clinically is the monoclonal antibody Garadacimab, which is approved for the treatment of hereditary angioedema (HAE), caused by the excess production of BK resulting in vascular leakage and inflammation. ${ }^{15}$ Interestingly, patients who suffer from this condition do not present an increased risk of cardiovascular disease and HAE is not associated with thrombosis, highlighting the discrete mechanisms of FXII activation in contributing to a diverse range of pathologies. Several studies have also suggested that aberrant activation of the procoagulant intrinsic pathway of coagulation and the proinflammatory KKS could play a significant role in the pathogenesis of COVID-19 and that therapeutic intervention on this axis may aid in alleviating acute symptoms associated with infection by SARS-CoV-2, including pulmonary edema and dysregulated coagulopathy; ${ }^{22-24}$ at the time of writing this article, Garadacimab was being evaluated in clinical trials for COVID-19 patients displaying respiratory distress (clinical trial identifier NCT04409509).

As molecules that straddle the void between large antibody biologics and small-molecule inhibitors, macrocyclic peptides have emerged as promising chemotypes owing to their potent and selective inhibitory profiles, ability to disrupt challenging protein-protein interactions, as well as improved resistance to proteolysis compared to their linear peptide counterparts. ${ }^{25}$ In the context of FXIIa inhibition, Heinis and co-workers have very recently reported that a bicyclic peptide inhibitor, FXII900 (a highly engineered analogue of the previously identified FXII618 discovered by phage display), ${ }^{18,20,21}$ exhibited potent antithrombotic activity in vivo and serves as a bona fide candidate for further development. This work provides important proof of principle for the application of cyclic peptides for the treatment of thrombotic disorders through the inhibition of FXIIa. ${ }^{20,21}$

Herein, we describe the use of the Random Nonstandard Peptide Integrated Discovery (RaPID) mRNA display technology to discover potent and selective cyclic peptide inhibitors of the FXIIa catalytic domain with a view to discovering new chemotypes for medicinal chemistry campaigns on this important therapeutic target. ${ }^{25-28}$ We chose to use this technology over more widely employed phage display techniques for the following reasons: (1) there are limits to the complexity of peptide display libraries generated in Escherichia coli, with transformation efficiencies in the region of $10^{7}-10^{8}$ library members; (2) phage display technology relies on living cells and therefore toxic sequences may never be represented in the selection process; and (3) in general, only proteinogenic amino acids can be displayed. ${ }^{29}$ In contrast, the mRNA display libraries are typically $>10^{12}$ (one trillion) members, and genetic code reprogramming allows for the incorporation of nonproteogenic amino acids to further expand the chemical space accessible. mRNA display is therefore a powerful complementary technique for the in vitro selection of high-affinity peptides and proteins and has been used for the discovery of a number of tool molecules and medicinal chemistry leads over the past decade. ${ }^{30-32}$

\section{RESULTS AND DISCUSSION}

We initially performed a RaPID screen to identify cyclic peptide inhibitors of FXIIa (Figure 2A). Briefly, this entailed the use of a semirandom DNA library comprising an initial start codon (that was genetically reprogrammed during translation to encode $\mathrm{N}$-chloroacetyl-tyrosine) flanked by 415 random codons (NNK with $\mathrm{N}=\mathrm{A}, \mathrm{C}, \mathrm{G}$, or $\mathrm{T}$ and $\mathrm{K}=\mathrm{G}$ or $\mathrm{T}$ ) and a final Cys codon, in addition to adjacent sequences required for transcription, ligation to puromycin, and PCR amplification. ${ }^{28,30-33}$

This DNA library was first transcribed into mRNA, which was then ligated to puromycin and translated to yield a cyclic peptide-mRNA fusion library (in excess of $10^{12}$ molecules). Because puromycin mimics a $3^{\prime}$ aminoacyl-tRNA, it is recognized by the ribosome and incorporated, establishing a covalent bridge between each cyclic peptide and its cognate mRNA. Cyclization was effected by genetic code reprogramming of the N-terminal formyl-Met to N-chloroacetyl-L-Tyr (L- 

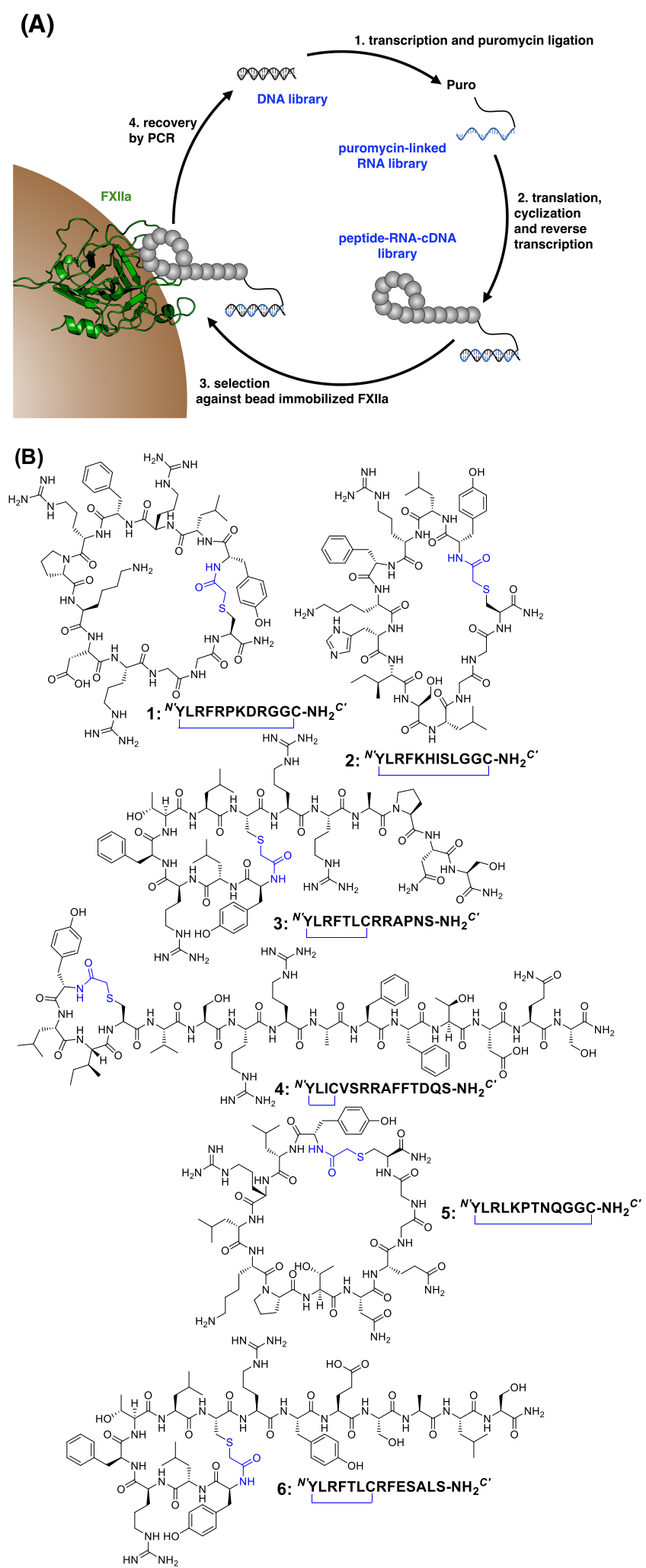

Figure 2. (A) Schematic for the discovery of cyclic peptide inhibitors of $\beta$ FXIIa using RaPID mRNA display technology; (B) cyclic peptide targets 1-6 selected for synthesis and profiling following six rounds of selection.

ClAc-Tyr) (through the use of the flexible in vitro translation (FIT) system). ${ }^{33}$ This electrophilic $\mathrm{N}$-terminal residue spontaneously induces cyclization through the sulfhydryl side chain of a downstream Cys residue following translation to generate a macrocyclic peptide. Following repeated counterselection (to remove ligands that bind the immobilization matrix), we panned the peptide library against the biotinylated $\beta$-subunit of FXIIa immobilized on streptavidin beads to enrich the FXIIa ligands, with an enriched DNA library subsequently recovered by reverse transcription-polymerase chain reaction (RT-PCR).

After five iterative rounds of library synthesis, affinity selection, and recovery, the final DNA library was sequenced to identify FXIIa ligands (see the Supporting Information). Based on frequency and sequence diversity in the sequenced library, we selected six macrocyclic peptides 1-6 for FXIIa inhibition studies and further characterization (Figure 2B; see the Supporting Information). These peptides possessed varied topologies, including head-to-tail cyclic peptides (1, 2, and 5) and lariat-type structures with ring sizes ranging from 4 to 7 residues in 3,4 , and 6 .

We next embarked on the synthesis of the six selected cyclic peptide targets 1-6 using Fmoc-strategy solid-phase peptide synthesis (Fmoc-SPPS). Specifically, Rink amide-functionalized polystyrene resin was loaded with the C-terminal amino acid in each of the target sequences, followed by iterative cycles of Fmoc-deprotection and peptide elongation via iterative coupling and deprotection cycles (Scheme 1). Following coupling of the N-terminal L-Tyr and Fmocdeprotection for each of the peptides, chloroacetic acid was coupled. At this point, the linear peptides were cleaved from solid support with concomitant side-chain deprotection through treatment with a trifluoroacetic acid-based cocktail. The peptides were then treated with 5 vol \% Hünig's base in $1: 1 \mathrm{v} / \mathrm{v}$ water $/ \mathrm{MeCN}$ to effect cyclization and purified by reverse-phase HPLC to afford $\mathbf{1 - 6}$ in $8-24 \%$ yield based on the original resin loading. In addition, we also synthesized the validated bicyclic peptide FXIIa inhibitor FXII618 to use as a positive control using the methods previously reported by Heinis and co-workers. ${ }^{18}$

Cyclic peptides 1-6 and FXII618 were next assessed for their inhibitory activity against human $\alpha$ FXIIa using a continuous colorimetric assay. Briefly, the chromogenic tripeptide substrate D-Pro-Phe-Arg-p-nitroanilide was employed, which, upon hydrolysis by FXIIa, leads to the liberation of $p$-nitroaniline that can be quantified by monitoring the absorbance at $\lambda=405 \mathrm{~nm}$. By examining the enzyme activity over a diverse range of inhibitor concentrations, $\mathrm{IC}_{50}$ values were determined. Gratifyingly, of the six cyclic peptides identified, five displayed an $\mathrm{IC}_{50}<400 \mathrm{nM}$ (Table 1). The most potent cyclic peptide inhibitor of FXIIa identified was the head-to-tail cyclic peptide 1 , which exhibited an $\mathrm{IC}_{50}$ of $62 \mathrm{nM}$. The previously reported FXII618 had an $\mathrm{IC}_{50}$ of $142 \mathrm{nM}$ in this assay, which is in good agreement with the previously reported activity. ${ }^{18}$ The only inactive molecule from those selected was lariat $4\left(\mathrm{IC}_{50}>100 \mu \mathrm{M}\right)$, which possessed a very small cyclic peptide comprising four amino acid residues fused to a long linear tail. Because the RaPID screen only identifies binders of the target protein, one possible explanation for the failure of peptide 4 to inhibit the catalytic function of FXIIa may lie in off-target binding of 4 to a site on the FXIIa surface distant from the active site. Alternatively, 4 may be a viable substrate of the FXIIa enzyme and thus undergo cleavage events, which may outcompete its ability to inhibit the enzyme. We also screened the FXIIa leads in the presence of bovine serum albumin (BSA) to assess whether plasma protein binding would have a detrimental effect on the inhibitory 
Scheme 1. Schematic Depicting the Solid-Phase Strategy for the Synthesis of Selected Head-to-Tail Cyclic Peptides 1, 2, and 5 (Left) and Lariat-Type Cyclic Peptides 3, 4, and 6 (Right)

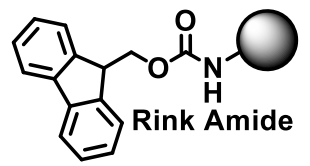

(A) Deprotect:

$20 \%$ (v/v) piperidine/DMF, $2 \times 10 \mathrm{~min}$, rt.

(B) Couple:

Fmoc-AA-OH, Oxyma, DIC, 2 h, rt.

(C) Cap:

$10 \%(v / v) \mathrm{Ac}_{2} \mathrm{O} / \mathrm{Pr}_{2} \mathrm{EtNH}, 10 \mathrm{~min}$, rt.

(D) Cleave:

90:5:5 (v/v/v) TFA: $\operatorname{Pr}_{3} \mathrm{SiH}: \mathrm{H}_{2} \mathrm{O}, 2$ h, rt.

(E) Cyclize:

$5 \%(\mathrm{v} / \mathrm{v}) i \mathrm{Pr}_{2} \mathrm{EtNH}, 2 \mathrm{~h}$, rt.
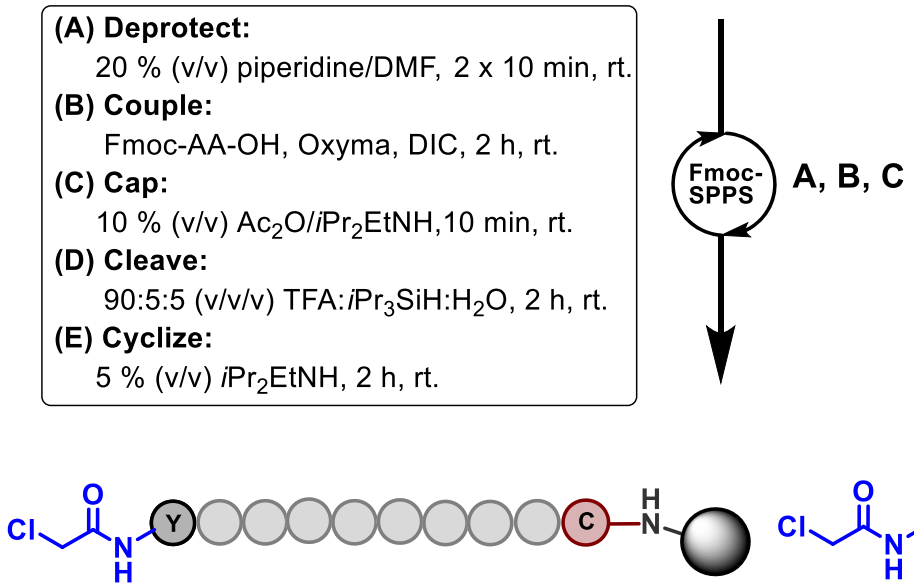

$\mathrm{Cl}^{\mathrm{H}} \mathrm{O} O \mathrm{OCOOOO}-\mathrm{COO}^{\mathrm{H}}-\mathrm{CO}$<smiles>CCCCCC</smiles><smiles>CC(C)CC(C)C</smiles><smiles>NC(=O)C1CCC2CC3CCC(CC3)CC2CC1CC1CCC2CCC(CC2)CC1CS</smiles><smiles>NC(=O)[C@H](CSCC(=O)NC1=Cc2cc3ccc2C=CC(=C3)C=C1)NC1=Cc2ccc3ccc(cc3c2)C=C1</smiles>

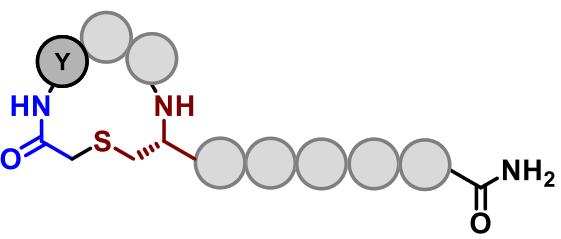

1,2 and 5

3, 4 and 6

Table 1. IC $_{50}$ Values for Cyclic Peptides 1-6 and FXII618 against Human $\alpha$ FXIIa (hFXIIa) in the Presence and Absence of BSA and $\mathrm{FXa}^{a}$

$\begin{array}{lccc}\text { peptide } & \begin{array}{c}\text { human } \alpha \mathrm{FXIIa} \\ \mathrm{IC}_{50}(\mathrm{nM})\end{array} & \begin{array}{c}\text { human } \alpha \mathrm{FXIIa} \mathrm{IC}_{50} \\ (\mathrm{nM}) \text { with BSA }\end{array} & \begin{array}{c}\text { human FXa } \\ \mathrm{IC}_{50}(\mathrm{nM})\end{array} \\ \mathbf{1} & 62 & 61 & 59000 \\ \mathbf{2} & 234 & 311 & 17000 \\ \mathbf{3} & 97 & 157 & 35000 \\ \mathbf{4} & >100000 & \mathrm{~N} . \mathrm{D} . & >100000 \\ \mathbf{5} & 331 & 611 & >100000 \\ \mathbf{6} & 372 & 673 & 2200 \\ \text { FXII618 } & 142 & 173 & \text { N.D. } \\ { }^{a} \text { N.D., not determined; BSA, bovine serum albumin. } & \end{array}$

activity of the peptide leads (see Table 1 and Supporting information). Pleasingly, the addition of BSA did not hinder the inhibitory activity for any of the cyclic peptides.

Having determined the inhibitory activity of the cyclic peptides against hFXIIa, we next counterscreened 1-3, 5, and 6 against a panel of related and functionally important serine proteases within the coagulation cascade to gauge the selectivity. Specifically, we assessed the compounds against FIIa (thrombin), FXa, and FXIa (see the Supporting Information for data). Cyclic peptide FXIIa inhibitors 1-3 displayed 100-1000-fold selectivity over the structurally related FXa. Head-to-tail cyclic peptides $\mathbf{1}$ and $\mathbf{2}$ were also highly selective over structurally related thrombin and FXIa. Head-to-tail cyclic peptide 5, which exhibited an $\mathrm{IC}_{50}$ of 330 $\mathrm{nM}$ against FXIIa, was completely inactive against the protease panel at a concentration of $33 \mu \mathrm{M}$ and represented the most selective peptide in the series (Table 1 and Supporting 
Information). In contrast, however, peptide $\mathbf{6}$ displayed significant inhibitory activity against FXa (Table 1). Based on the $\alpha$ FXIIa inhibitory potency of 1-6, together with their selectivity for FXIIa, we triaged compounds 4 and 6 from further screening efforts. A striking observation from these data was the very different selectivity profiles for FXIIa over FXa despite the high sequence homology of peptides 1, 2, and $\mathbf{5}$. Upon closer analysis of the sequences, we identified a basic His residue at position 6 of peptide 2 (compared to Pro in peptides 1 and 5) and hypothesized that this may be responsible for the inhibitory activity observed against FXa. To test this hypothesis, we synthesized an "Ala mutant" of peptide $\mathbf{2}$ in which we substituted the His residue with an Ala (see the Supporting Information). This resulted in a molecule with similar potency $\left(\mathrm{IC}_{50}=180 \mathrm{nM}\right)$ but with improved selectivity over FXa $\left(\mathrm{IC}_{50}=41000 \mathrm{nM}\right)$.

Selectivity of Lead Cyclic Peptides 1, 3, and 5 against a Broader Panel of Proteases. We next evaluated peptides $\mathbf{1}, \mathbf{3}$, and $\mathbf{5}$ against a broader panel of serine proteases including plasma kallikrein $(\mathrm{PK})$, urokinase-type plasminogen activator (uPA), trypsin, plasmin, and FVIIa, the latter of which is positioned on the extrinsic pathway of coagulation (Table 2).

Table 2. Selectivity of Lead Peptides 1, 3, and 5 against Plasma Kallikrein (PK), Urokinase-Type Plasminogen Activator (uPA), FVIIa, Trypsin, and Plasmin

\begin{tabular}{lcrr} 
protease & $\begin{array}{c}\text { peptide 1 } \\
\left(\mathrm{IC}_{50} \mathrm{nM}\right)\end{array}$ & $\begin{array}{c}\text { peptide 3 } \\
\left(\mathrm{IC}_{50} \mathrm{nM}\right)\end{array}$ & $\begin{array}{c}\text { peptide 5 } \\
\left(\mathrm{IC}_{50} \mathrm{nM}\right)\end{array}$ \\
$\mathrm{PK}$ & $>100000$ & 43000 & $>100000$ \\
$\mathrm{uPA}$ & $>100000$ & $>100000$ & $>100000$ \\
FVIIa & $>100000$ & $>100000$ & $>100000$ \\
trypsin & $>31000$ & 61000 & 12000 \\
plasmin & $>100000$ & 61000 & $>100000$ \\
\hline
\end{tabular}

Again, we were pleased to observe that peptides 1, 3, and 5 had greater than 1000-fold selectivity over the protease panel. Peptides $\mathbf{1}$ and $\mathbf{5}$ proved to be the most selective against most of the enzymes, with $\mathbf{5}$ exhibiting some activity against trypsin, while peptide 3 exhibited moderate activity against trypsin, PK, and plasmin.

Alanine Scan of Cyclic Peptide 1 Reveals a Conserved Binding Motif. We next sought to elucidate the inhibitory contribution of each residue in lead peptides $\mathbf{1}$ and $\mathbf{5}$ using an "Ala scan", whereby each amino acid (except for the Cys residue at the cyclization site) was systematically replaced by Ala to give analogues 7-17 (of peptide 1) and 18-28 (of peptide 5). Each of the target peptides was synthesized according to the Fmoc-SPPS methods described earlier in good overall yields (4-12\%, see the Supporting Information).

Evaluation of the Ala scan series 7-28 against hFXIIa revealed that substitution of the amino acid residues in positions 1-5 with an Ala in both peptides reduced the FXIIa inhibitory activity by $2-4$ orders of magnitude when compared to $\mathbf{1}$ and $\mathbf{5}$ (Table 3). This suggested that the relatively conserved amino acids at these positions in the two peptides (vide infra) are crucial for inhibitory activity. In contrast, substitution at positions 6-9 had relatively little effect on potency, suggesting that these amino acid side chains do not form any significant interactions with FXIIa. However, intriguingly, substitution of the Gly residues in positions 10 and 11 in the two lead peptides also had a detrimental effect on the inhibitory activity, with peptides 16 and 17 and 27 and 28 losing 100-fold and 1000-fold activity against FXIIa, respectively. With two hydrogen substituents at the $\alpha$-center, Gly is capable of adopting many more conformations than Ala, with this conformational freedom providing additional flexibility to the peptide backbone. ${ }^{34}$ The observation that substitution to a more conformationally restricted side chain was detrimental to potency suggests that flexibility at positions 10 and 11 of the cyclic scaffold is a key structural feature, potentially enabling the peptides to adopt their bioactive conformation to position the putative active site-binding pentapeptide motif (positions 1-5) into the active site.

Sequence Analysis of the Discovered RaPID Hits. Having revealed key structure-activity data from the Ala scan, we next performed sequence alignments of the original hits from the RaPID screen (1-6). We observed that five of the six peptides originally identified in the RaPID screen had a short but highly conserved sequence motif at positions 1-5, consisting of a YLRFR domain in peptide 1, a YLRFK in peptide 2, YLRFT in peptides 3 and $\mathbf{6}$, and a YLRLK in peptide 5. Interestingly, these conserved sequences showed homology with the previously reported bicyclic peptide FXII618 ${ }^{18}$ (discovered through a phage display method) in which the active site-binding sequence was hypothesized to be LRFR. This sequence homology led us to hypothesize that these highly conserved pentapeptide motifs are responsible for binding the active site of FXIIa, consistent with our observation that mutation of any of the amino acids in the sequence to Ala leads to a loss in inhibitory potency. To assess whether these short peptide sequences had any inhibitory activity against FXIIa alone, we synthesized the short linear motif (29), a cyclized variant containing the YLRFR sequence (30) from peptide 1 and the lariat portion (31) from peptides 3 and 6 (see the Supporting Information).

The peptides were evaluated for their inhibitory activity against hFXIIa (Table 4). Interestingly, while the short linear peptide 29 had no inhibitory activity against FXIIa, cyclic peptide 30 possessed marginal activity $\left(\mathrm{IC}_{50}=\sim 200 \mu \mathrm{M}\right)$ and cyclic peptide 31 , which possessed a larger ring size, was $>100$ fold more active as compared to $30\left(\mathrm{IC}_{50}=3.8 \mu \mathrm{M}\right)$. These observations suggest that the conformation of the cyclic peptide and the correct presentation/orientation of the binding epitope to the FXIIa active site are necessary for the potent inhibitory activity that we observe with the cyclic peptides discovered through RaPID mRNA display.

Substitution of Phe4 within Cyclic Peptide 1. Our preliminary SAR data generated through Ala scanning showed that a conserved pentapeptide motif (residues 1-5) in peptides 1 and 5 was crucial for inhibitory activity. As such, we chose to perform a more detailed SAR exploration on the most potent cyclic peptide $\mathbf{1}$ with a view to generating a more potent inhibitor of FXIIa. Toward this end, a library of 25 cyclic peptide analogues (32-56) was designed and synthesized. The majority of the molecules possessed substitution of the Phe residue at position 4 in 1 with ortho-, meta-, and para-substituted electron-withdrawing (32-40) and electron-donating $(41-47)$ moieties, as well as compounds (48-50) with heteroaromatic substitution to probe for additional interactions (see Table 5 and Supporting Information). Most of the analogues proved to be equipotent to lead peptide 1 (Table 1). Interestingly, compounds 32-34, bearing fluorine substitutions, did not lead to improvement in activity. This was surprising given that a fluorinated Phecontaining analogue of FXII618 (that possesses a similar 
Table 3. $\mathrm{IC}_{50}$ Values for Cyclic Peptides 1 and 5 and “Ala scan” Analogues 7-28 against hoFXIIa

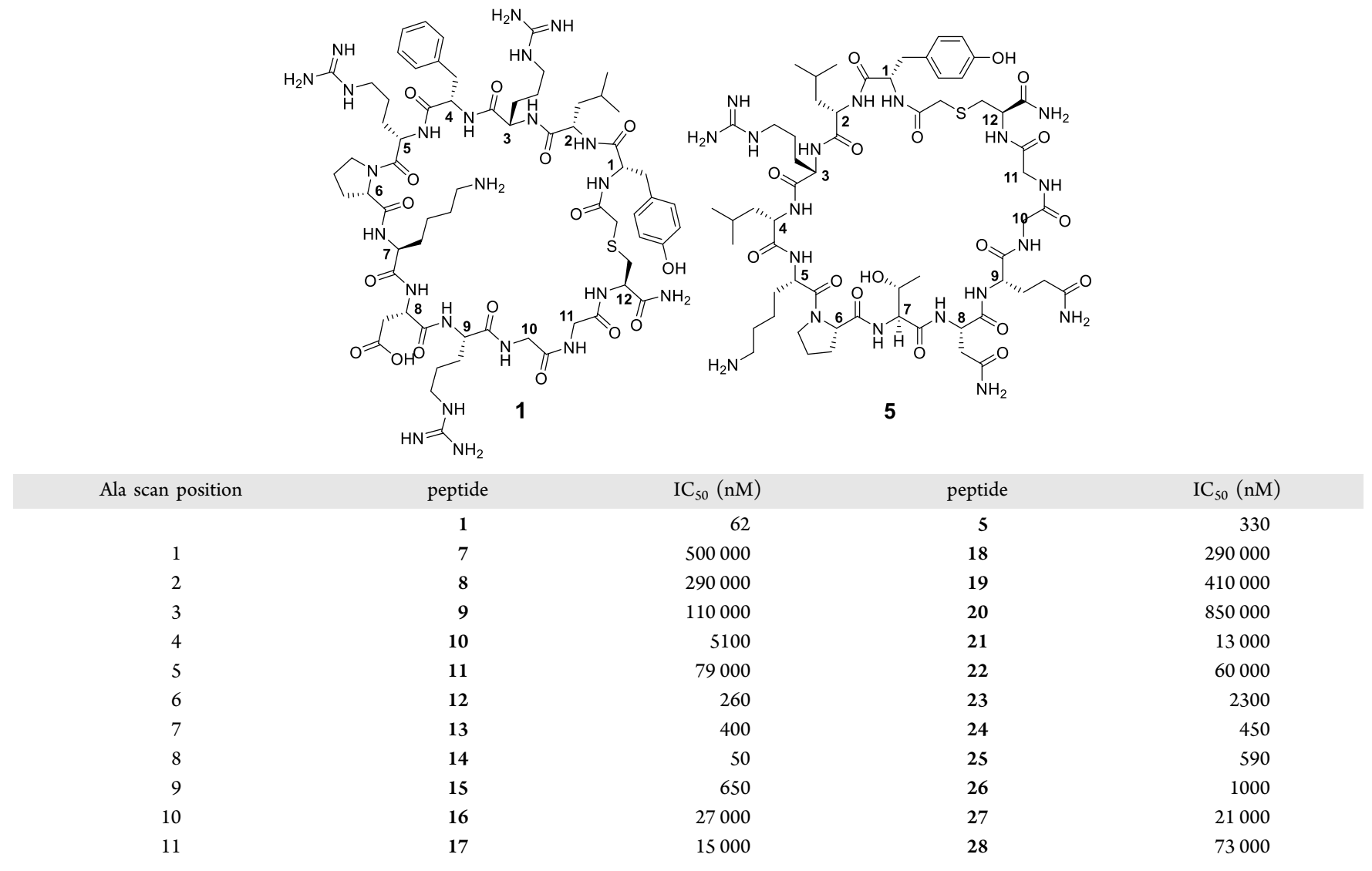

Table 4. Inhibitory Activity of Short Linear and Cyclized Sequences from the Lead Peptides Identified from the RaPID Screen ${ }^{a}$

\begin{tabular}{clc} 
peptide & \multicolumn{1}{c}{ sequence } & $\mathrm{IC}_{50}(\mathrm{nM})$ \\
29 & $N^{\prime}$-YLRFR- $C^{\prime}$ linear & inactive \\
30 & $N^{\prime}$-YLRFRC- $C^{\prime}$ cyclized & 200000 \\
31 & $N^{\prime}$-YLRFTLC- $C^{\prime}$ cyclized & 3800
\end{tabular}

${ }^{a}$ Inactive, no inhibitory activity at $2 \mathrm{mM}$.

sequence motif to 1) showed a 10-fold improvement in inhibitory activity against FXIIa. ${ }^{18}$ These observations suggest that while there is similarity between the putative active sitebinding sequence of peptide 1 and the bicyclic peptide FXII618, ${ }^{18}$ there must be subtle differences in the interactions established with the protease.

Analogues $\mathbf{5 1}$ and $\mathbf{5 2}$ bearing homoPhe and homoTyr residues and analogues $\mathbf{5 3}$ and $\mathbf{5 4}$ containing bulky side-chain substitutions were designed to reposition the aromatic side chain deeper into the S2 pocket. Additionally, a conformationally restrained tetrahydroisoquinioline derivative $\mathbf{5 5}$ was designed to lock the Phe side chain into a defined conformation. Interestingly, analogues 51 and 52 lost $>10$ fold activity (compared to 1 ). However, naphthylalaninecontaining analogues $\mathbf{5 3}$ and $\mathbf{5 4}$ were well tolerated $\left(\mathrm{IC}_{50} \mathrm{~s}\right.$ of 50 and $68 \mathrm{nM}$, respectively). The reduced activity of $\mathbf{5 0}$ (>1000-fold) may be owing to the side chain being locked into an unfavorable conformation.

Finally, cyclohexylalanine (Cha) analogue 56, designed to probe whether an aromatic side chain was important for inhibitory activity, was equipotent to $1\left(\mathrm{IC}_{50}=53 \mathrm{nM}\right)$. These data suggest that the interactions between the Phe residue in lead peptide 1 and FXIIa are likely van der Waals interactions rather than $\pi-\pi$ or cation $-\pi$ interactions. This also suggests that Cha can be used as an inert, noncanonical substitution for Phe in future FXIIa inhibitors.

Substitution of Tyr1 within Cyclic Peptide 1. All members of the $>10^{12}$ randomized peptide sequences panned against $\beta$ FXIIa have an L-Tyr as the initiating amino acid. This is a consequence of the genetic code reprogramming in which an L-ClAc-Tyr residue is reprogrammed for Met to facilitate cyclization with a sulfhydryl side chain of Cys. As such, a series of analogues were proposed whereby Tyr1 was substituted with aliphatic and aromatic amino acids, with the view to discovering novel inhibitors with improved potency (Table 6). Analogues 57-74 possessed aromatic amino acid side chains with electron-rich and electron-deficient substituents in the ortho-, meta-, and para-positions (or heteroaromatic 2-, 3-, and 4-pyridyl side chains for 67-69). Additionally, like the Phe4substituted series, we also sought to probe extension of the amino acid residue by incorporating homoPhe and homoTyr residues in $\mathbf{5 1}$ and $\mathbf{5 2}$, respectively (Table 6). Finally, two analogues were designed with aliphatic amino acid substitutions, namely, Cha and Val, to probe the potential importance of any $\pi-\pi$ and cation $-\pi$ interactions with the Tyr residue in lead peptide 1 . This library of 22 analogues was prepared by Fmoc-SPPS as previously described, and the desired cyclic peptides were obtained in good overall yield $(7-17 \%$, see the Supporting Information).

Following screening of these inhibitors against hFXIIa, we were surprised to discover that none of these substitutions were well tolerated. The degree to which each structure 
Table 5. Structures and Inhibitory Activity of Phe4-Substituted Cyclic Peptide Analogues of 1

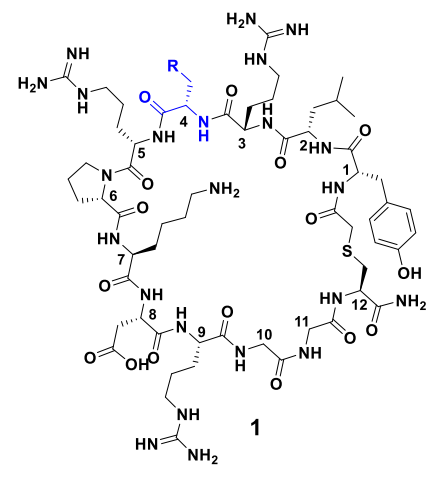

\begin{tabular}{|c|c|c|c|c|c|}
\hline Peptide & Substitution ( $\mathrm{R}=$ ) & $\mathrm{IC}_{50}(\mathrm{nM})$ & Peptide & Substitution & $\mathrm{IC}_{50}(\mathrm{nM})$ \\
\hline 1 & & 65 & 44 & & 60 \\
\hline 32 & & 53 & 45 & & 120 \\
\hline 33 & & 66 & 46 & & 560 \\
\hline 34 & & 46 & 47 & & 260 \\
\hline 35 & & 42 & 48 & & 96 \\
\hline 36 & & 93 & 49 & & 170 \\
\hline 37 & & 110 & 50 & & 120 \\
\hline 38 & & 120 & 51 & & 740 \\
\hline 39 & & 160 & 52 & & 560 \\
\hline 40 & & 90 & 53 & & 50 \\
\hline 41 & & 43 & 54 & & 68 \\
\hline 42 & & 73 & 55 & & 22000 \\
\hline 43 & & 56 & 56 & & 53 \\
\hline
\end{tabular}

diminished the inhibitory potency varied extensively, from a $\sim 6$ to $>6000$-fold reduction in activity. Interestingly, even substitutions that closely resembled the Tyr side chain (Phe in 57 and 4-methoxyPhe in 72) lost almost 10-fold activity, 
Table 6. Structures and Inhibitory Activity of Tyr1 Substituted Cyclic Peptide Analogues of 1

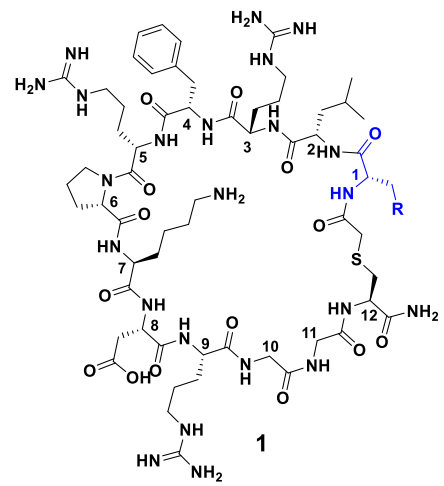

\begin{tabular}{|c|c|c|c|c|c|}
\hline Peptide & Substitution $(\mathrm{R}=)$ & $\mathrm{pIC}_{50}(\mathrm{M})$ & Peptide & Substitution & $\mathrm{pIC}_{50}(\mathrm{M})$ \\
\hline 1 & & 65 & 67 & & 11000 \\
\hline 57 & & 480 & 68 & & 15000 \\
\hline 58 & & 120000 & 69 & & 12000 \\
\hline 59 & & 84000 & 70 & & 400000 \\
\hline 60 & & 74000 & 71 & & 640 \\
\hline 61 & & 14000 & 72 & & 530 \\
\hline 62 & & 3100 & 73 & & 90000 \\
\hline 63 & & 8100 & 74 & & 150 \\
\hline 64 & & 350 & 75 & & 410000 \\
\hline 65 & & 650 & 76 & & 370000 \\
\hline 66 & & 470 & 77 & & 140000 \\
\hline & & & 78 & & 210000 \\
\hline
\end{tabular}

emphasizing the importance of the para-phenolic moiety for activity. Analogues 64-66 containing fluoroPhe substitutions were the most active in the series $\left(\mathrm{IC}_{50}=350-650 \mathrm{nM}\right)$ but were still 5-10-fold less potent than 1 . When the inhibitory data for the trifluoromethyl-, cyano-, and methoxy-substituted analogues $(58-60,61-63$, and 70-72) are compared, it is apparent that the ortho-position is particularly disfavored, with bulkier $o$-methoxy and $o$-trifluoromethyl substitutions resulting in greater than 3 orders of magnitude drop in activity. Meanwhile, pyridylAla analogues 67-69, which are considered electron-deficient by virtue of the inductive electron-withdrawing effect exerted by the nitrogen heteroatom, reduced the inhibitory activity by $>180$-fold $\left(\mathrm{IC}_{50}=11-15 \mu \mathrm{M}\right)$, irrespective of the positioning of the heteroatom. Compounds 73 and 74 were designed to retain the para-phenol but were additionally substituted with an electron-deficient ortho-nitro (73) or ortho-fluoro (74) group. We postulated that this functionality would retain some of the electron-rich character at position 1 while increasing the acidity of the phenolic group to enhance potential hydrogen-bonding interactions. Interestingly, while 73 led to $>10000$-fold reduction in potency compared to 1 , the ortho-fluoroPhe substituted analogue $\mathbf{7 4}$ was almost equipotent to $1\left(\mathrm{IC}_{50} 150 \mathrm{nM}\right.$ vs $65 \mathrm{nM}$ for 1$)$. Extension of the amino acid side chain in homoPhe 75 and homoTyr 76 analogues resulted in a dramatic drop in the inhibitory activity ( $\mathrm{IC}_{50} 420 \mu \mathrm{M}$ and $370 \mu \mathrm{M}$, respectively), which was also the case in the Cha analogue $77\left(\mathrm{IC}_{50} 140 \mu \mathrm{M}\right)$ and the Val analogue $78\left(\mathrm{IC}_{50} 210 \mu \mathrm{M}\right)$. Taken together, these data suggest that the key interaction of the Tyr 1 residue with FXIIa involves the $\pi$-system, i.e., via $\pi-\pi$ and cation $-\pi$ interactions. However, based on the dramatic loss of activity when Tyr was replaced with structurally similar aromatic amino acids, if such interactions occur, they must be very finely tuned.

Molecular Dynamics Simulations of Peptide 1 with FXIla. In an attempt to explain the striking SAR generated for the analogues of $\mathbf{1}$ with Tyr1 substitutions, we exploited a combination of ligand docking and molecular dynamics simulations to help rationalize the binding pose of $\mathbf{1}$ (see the Supporting Information for experimental details). Recently, several crystal structures of FXIIa have been reported. ${ }^{16,35,36}$ Using the structure of human FXIIa bound to a macrocyclic peptide ligand (PDB ID 6L63; ligand named "F3") as a template, peptide 1 was manually docked into the FXIIa active site. $^{35}$ This initial docking pose served as the starting configuration for our molecular dynamics (MD) simulations (Figure 3). After initially positioning the peptide into the Factor XIIa active site, with Arg3 forming the canonical salt bridge with Asp557 and all other residues in tolerated and sensible starting positions, the system was immersed in an explicit solvent and minimized, which was followed by triplicate $300 \mathrm{~ns}$ MD simulations. Triplicate simulations initiated from the structure FXIIa modeled with peptide 1 were similar, with the protein-ligand complex reaching a stable pose within 100-150 ns in each random seed replicate. The protein (backbone) RMSD converged rapidly (first 50 $\mathrm{ns}$ ), with the ligand stabilizing after 100-150 ns (see the Supporting Information).

Even during this initial stabilization period, peptide 1 remained stably bound to FXIIa, with the buried Arg3 anchoring the peptide to the FXIIa structure (where it forms the canonical ligand/protein salt bridge with Asp557). There were, however, some notable structural differences between the manually modeled structure and the stable pose obtained through the MD simulations. Most notably, Arg9 and Tyr1 move from the initial modeled positions pointing away from FXIIa and into the solvent, to a final pose in which Tyr1 is 

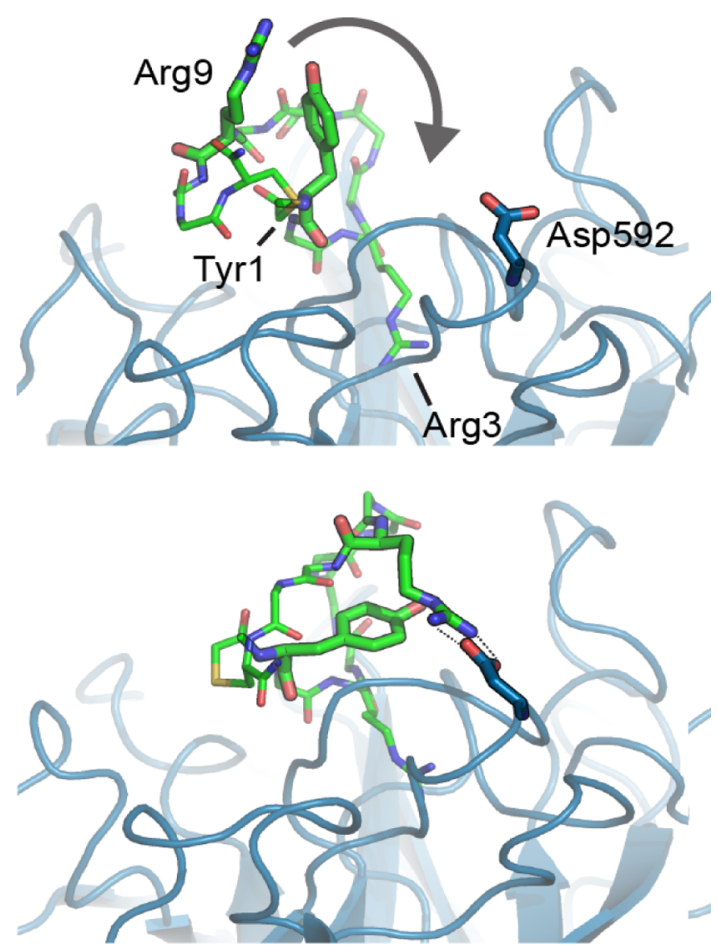

Figure 3. Structural comparison of the first (top) and final (bottom) frames of a representative MD simulation of FXIIa and cyclic peptide 1, highlighting the main changes in the peptide that occurred during the initial stabilization period (first $\sim 100 \mathrm{~ns}$ ). Carbon atoms of peptide 1 are colored green. During stabilization, Tyr 1 moves toward the core of the peptide, and Arg9 bends over to interact with residue Asp592. Replicate simulations resulted in similar final poses (see the Supporting Information).

partially buried to form the core of the peptide and Arg9 forms salt bridge interactions with Asp592 and Glu510 (Figures 3 and 4). These observations provide a plausible molecular explanation as to why Tyr1 is critical for activity and why small structural deviations from this amino acid were not tolerated (see Table 6). This putative role of Tyr1 for the activity of peptide $\mathbf{1}$ is particularly striking given that it was fixed during

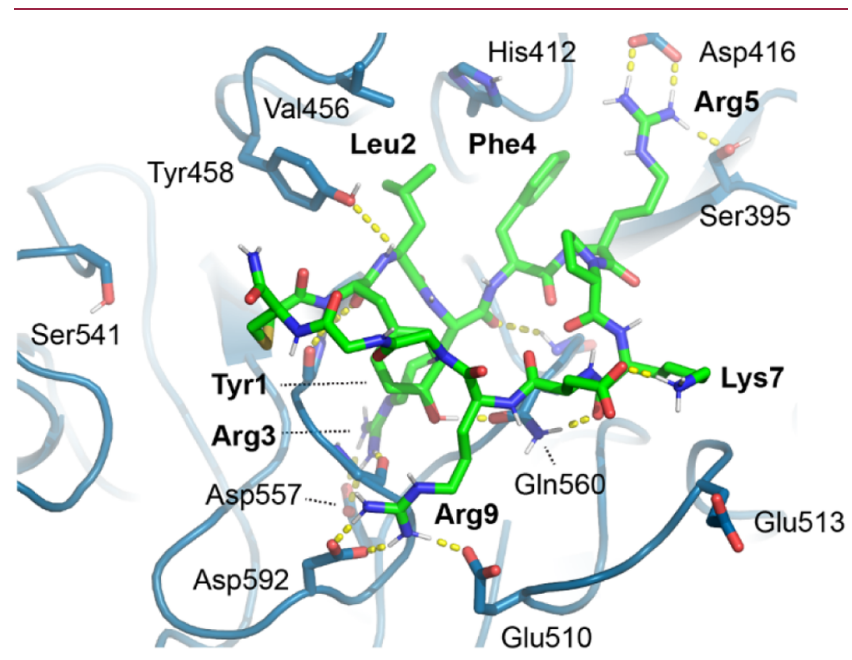

Figure 4. Key interactions between FXIIa and cyclic peptide 1. A representative pose (top-scoring cluster from the cluster analysis of replicate trajectories) from simulations of peptide 1 and FXIIa. Carbon atoms of peptide $\mathbf{1}$ are colored green. the mRNA display selections and provides useful information for future inhibitor design.

By analyzing the last $200 \mathrm{~ns}$ of each simulation (i.e., post stabilization), we found that peptide $\mathbf{1}$ is held in place via several key interactions that persist for the majority of the simulation time (Figures 4 and 5). Importantly, Arg3 interacts

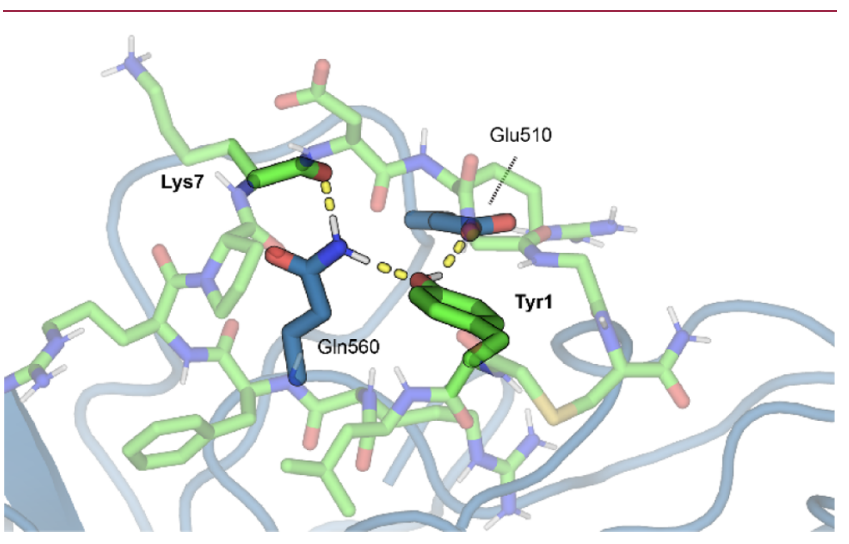

Figure 5. Key interactions between FXIIa and Tyr1. A representative pose (top-scoring cluster) from simulations of peptide $\mathbf{1}$ and FXIIa. Tyr1 occupies the core of the peptide and forms hydrogen bonds with Gln560 and Glu510. Carbon atoms of peptide 1 are colored green.

persistently with residues at the bottom of the active site pocket, including Asp557 (93\% frames), to anchor the peptide in position. Arg5 forms key interactions either with the side chain of Glu513 (31\%) or in a pocket formed by Asp416 (66\%) and Ser395 (63\%). Arg9 interacts directly with the side chain of Asp592 (65\%) and Glu510 (62\%) for much of the simulation. Other interactions include the $\pi-\pi$ interaction between Phe4 and His412 (52\%), Lys7 to Glu513 (38\%) or His538 (30\%), and several backbone-mediated interactions. In addition, van der Waals interactions between the side chains of Leu2 and a hydrophobic pocket formed by the side chains of Tyr458, Val456, and His412 contribute further to binding.

Substitution of Arg3 or Arg5 within Cyclic Peptide 1. As a final SAR exploration, we investigated the substitution of the Arg residues at positions 3 and 5 that were identified as key residues for inhibition from our Ala scan. Arg is a cleavage recognition residue at the $\mathrm{P} 1$ position of a number of plasma proteases and therefore has the potential to limit in vivo halflife. ${ }^{37}$ To introduce proteolytically stable Arg mimics and probe the effects of varying the length of the side chain and $\mathrm{p} K_{\mathrm{a}}$, a small library of analogues containing noncanonical amino acid substitutions of Arg3 (79-81) and Arg5 (82-84) was designed and synthesized. The Arg residues at positions 3 and 5 were substituted for ornithine, nor-Arg, and homo-Arg. In addition, we substituted the Arg at positions 3 and 5 of 1 for lysine in 85 and 86, respectively. Homo- and nor-Arg analogues were synthesized via a modified Fmoc-SPPS method that employed a late-stage on-resin guanidinylation step (see the Supporting Information for synthetic details). Evaluation of these cyclic peptides against FXIIa showed that homo-Arg substitution at position 3 was equipotent with lead peptide 1 (Table 7). However, substitution with nor-Arg, ornithine, or Lys resulted in a 10 - to 100 -fold reduction in potency. These observations were consistent with our docking and molecular dynamics studies that suggest that Arg3 in 1 forms an electrostatic interaction with Asp557 in the S1 pocket and that shorter amine side chains would likely lose this interaction. By 
Table 7. Structures and Inhibitory Activity of Arg Substituted Analogues at Positions 3 and 5 of Peptide 1

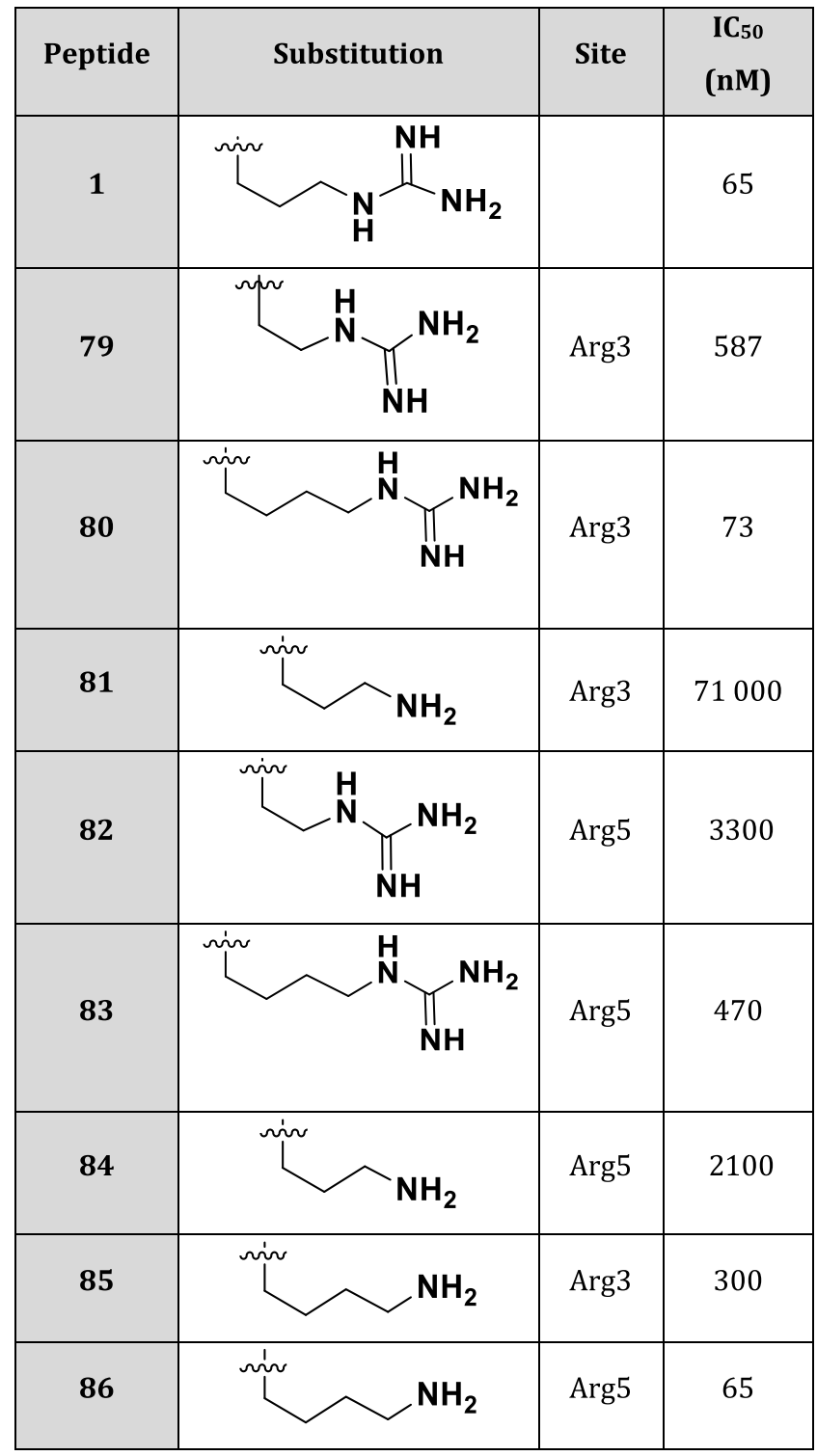

comparison, Lys substitution at position 5 in $\mathbf{8 6}$ resulted in a compound that was equipotent with the lead. However, substitution with nor-Arg, homo-Arg, or ornithine in 82-84 resulted in a 10- to 100 -fold reduction in potency.

Despite the generation of a large number of structural analogues of $\mathbf{1}$ and the identification of a number of key SARs, we did not identify an analogue that possessed any significant improvement in inhibitory activity against FXIIa. This perhaps highlights the ability of the RaPID mRNA display technology to identify ligands that are already optimized to a given protein target. Having performed this SAR study on 1 , we next moved to assess the activity of lead cyclic peptides 1, 2, 3, and 5 that emerged from the mRNA display in more sophisticated in vitro assays.

In Vitro Evaluation of Intrinsic Coagulation by FXIla Inhibitors 1, 2, 3, 5, and FXII618. Activated partial thromboplastin time (aPTT) and prothrombin time (PT) are routine blood tests carried out by physicians that measure the activity of the intrinsic and extrinsic pathways of coagulation, respectively. A potent and selective FXIIa inhibitor should prolong the aPTT but not the PT. Based on the potency and selectivity of the cyclic peptide FXIIa inhibitors 1, 2, 3, and 5, identified from the RaPID screen, we performed aPTT and PT assays at concentrations of 12.5 and $1.25 \mu \mathrm{M}$. Each of the inhibitors showed a clinically relevant prolongation of aPTT at a concentration of $12.5 \mu \mathrm{M}$, while 1 also showed an extended aPTT at $1.25 \mu \mathrm{M}$, significantly more pronounced than for the known inhibitor FXII618. ${ }^{18}$ Interestingly, 1, 2, and 3 marginally prolonged PT at the highest concentration tested $(12.5 \mu \mathrm{M})$. We hypothesized that despite the greater than 1000 -fold selectivity for FXIIa over FXa, this slight prolongation may be a consequence of the residual activity against FXa at this higher concentration (Figure 6).

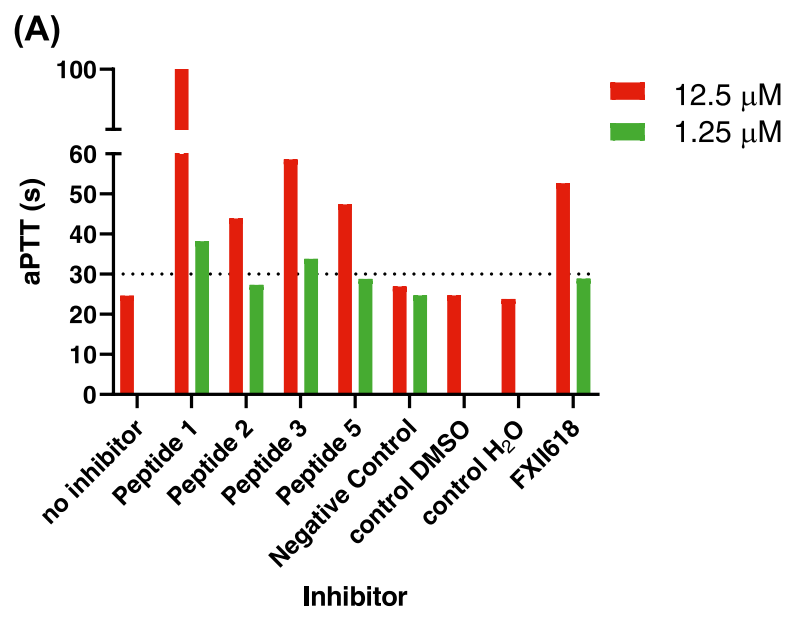

(B)

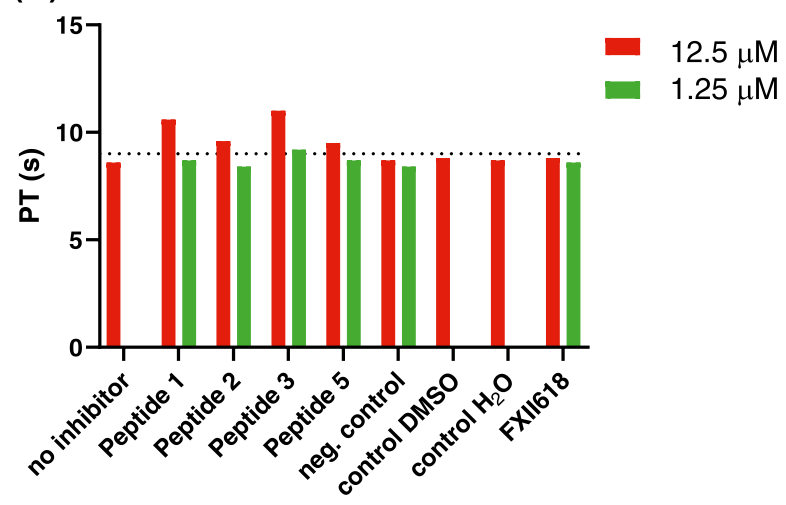

Inhibitor

Figure 6. Prolongation of clotting times in (A) aPTT and (B) PT assays at 12.5 and $1.25 \mu \mathrm{M}$ of cyclic peptides $1,2,3$, and 5 and FXII618. ${ }^{18}$ Horizontal dashed lines indicate clinically relevant clotting times for inhibitor-less plasma controls in aPTT and PT assays (see the Supporting Information). Negative control: YLrFRPKDRGGC cyclic peptide (a mutant of peptide 1, which is inactive against FXIIa at $100 \mathrm{mM})$.

Inhibition of Thrombin Generation by Lead Peptides $1,2,3$, and 5 . To further investigate the effect of the FXIIa inhibitors on coagulation, we performed plasma thrombin generation assays. Here, we used a calibrated automated thrombogram (CAT), which employs a fluorogenic thrombin substrate, thus allowing measurement of thrombin formation in 
plasma in real time. ${ }^{38}$ In contrast to aPTT and PT assays, the CAT allows for a large variation in the concentration and character of the trigger used and can therefore be implemented to detect subtle differences between inhibitors. The intrinsic pathway was triggered using ellagic acid and resulted in thrombin generation with a maximum concentration of thrombin of ca. $300 \mathrm{nM}$. Addition of FXIIa inhibitors 1, 2, 3 , and $5(0-8 \mu \mathrm{M})$ led to a dose-dependent decrease of thrombin generation and resultant prolongation in lag-time (see the Supporting Information). A negative control peptide based on peptide 1, in which Arg3 is substituted for D-Arg and has no activity against FXIIa at $100 \mathrm{mM}$, showed no effect under identical conditions. Thrombin generation was completely inhibited by addition of 1 at a concentration of $4 \mu \mathrm{M}$. $\mathrm{EC}_{50}$ values were derived from the peak height plotted as a function of the inhibitor concentration (Figure 7). In line with

\section{FXIla Inhibition summary peak height}

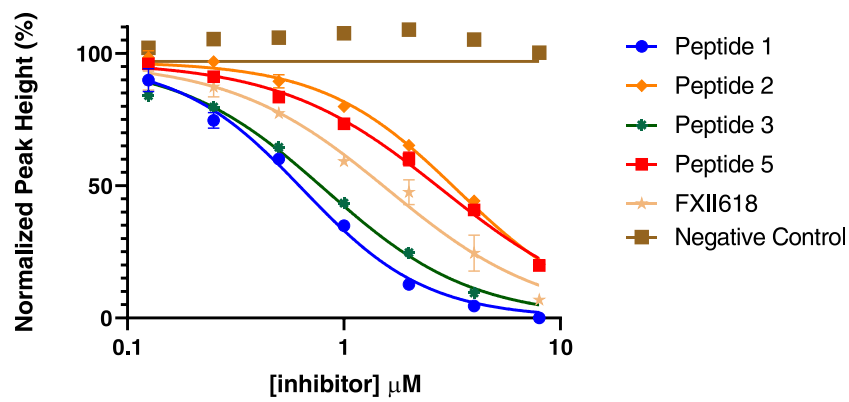

Figure 7. Reduction of peak height as determined by calibrated automated thrombogram (CAT) in the presence of increasing concentrations of the inhibitor. Thrombin generation was triggered via the intrinsic pathway of coagulation using ellagic acid. Data are represented as mean \pm standard deviation $(\mathrm{SD})$. Negative control $=$ YLrFRPKDRGGC cyclic peptide (a mutant of peptide 1, which is inactive against FXIIa at $100 \mathrm{mM}$ ).

the results obtained from aPTT assays, $1\left(\mathrm{EC}_{50}: 0.7 \mu \mathrm{M}\right)$ exhibited the most potent inhibitory activity when compared to $2\left(\mathrm{EC}_{50}: 3.2 \mu \mathrm{M}\right), 3\left(\mathrm{EC}_{50}: 1.4 \mu \mathrm{M}\right)$, and $5\left(\mathrm{EC}_{50}: 2.8 \mu \mathrm{M}\right)$. Next, a control experiment was performed in normal plasma as well as in FXII-deficient plasma in which coagulation was triggered via the extrinsic pathway using TF. Thrombin generation was monitored in the presence of the highest concentration of the inhibitor $(8 \mu \mathrm{M})$ used in the previous assay, whereby a selective inhibitor of FXIIa is expected to have no effect on thrombin generation in this assay. In this experiment, both $\mathbf{2}$ and $\mathbf{5}$ did not affect the peak height or total amount of thrombin formed (see the Supporting Information). However, peptide 1 showed a decrease in peak height, albeit with the total amount of thrombin formed being unaffected, which may reflect marginal off-target activity for this inhibitor (vide supra).

Determining the Inhibition of Contact Activation by Analysis of BK Formation. The proinflammatory nonapeptide $\mathrm{BK}$ is released from $\mathrm{HK}$ by the action of $\mathrm{PK}$ and is the final product of the KKS pathway that is initiated by FXIIa. Prevention of BK formation through FXIIa inhibition is therefore viewed as a promising avenue for anti-inflammatory development (vide supra). With our most potent and selective inhibitors $\mathbf{1}$ and $\mathbf{5}$ identified from the original RaPID screen, we sought to assess the ability of our lead cyclic peptides to inhibit BK formation by quantification through the use of a competitive enzyme-linked immunosorbent assay (ELISA). Briefly, pooled citrated human plasma was incubated with inhibitors at various concentrations before activation of FXII by the anionic clay particulate kaolin (Figure 8). Both $\mathbf{1}$ and $\mathbf{5}$

\section{Peptide 1}

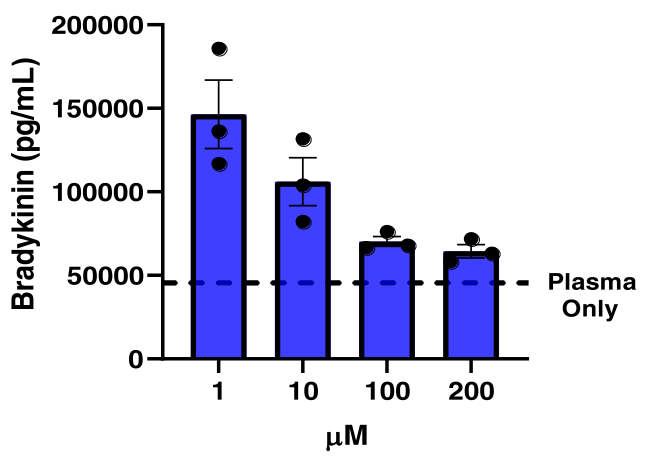

Peptide 5

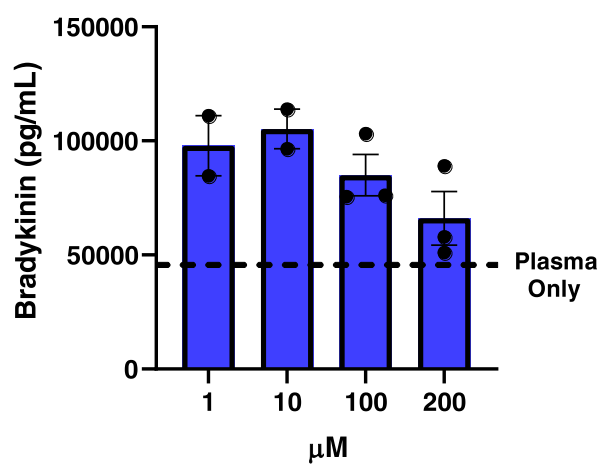

Figure 8. Cyclic peptide FXIIa inhibitors $\mathbf{1}$ and $\mathbf{5}$ inhibit BK release in a dose-dependent manner. FXII in citrated human plasma was contact-activated via incubation with kaolin and BK release measured by ELISA. The dashed line indicates BK levels in plasma only. Data are the means \pm standard error of the mean (SEM) (three technical replicates).

inhibited BK formation in a dose-dependent manner. For cyclic peptide 1, BK formation was inhibited such that concentrations were close to basal levels prior to initiation of contact activation by kaolin (Figure 8). Peptide 5 exhibited less potent inhibition of $\mathrm{BK}$ release, consistent with the lower FXIIa inhibitory potency compared to $\mathbf{1}$.

Plasma Stability of Lead Cyclic Peptides 1 and 5. One of the key benefits of cyclic peptides is a greater resistance to proteolysis. To gauge the plasma stability of peptides $\mathbf{1}$ and $\mathbf{5}$, and therefore their potential suitability for future in vivo applications, the compounds were incubated in pooled human plasma at $37{ }^{\circ} \mathrm{C}$ and aliquots at a range of timepoints were analyzed using ultraperformance liquid chromatography-mass spectrometry (UPLC-MS). Pleasingly, both 1 and 5 were resistant to proteolysis for up to $24 \mathrm{~h}$ (see the Supporting Information for data).

\section{CONCLUSIONS}

In summary, we have successfully employed reprogrammed mRNA display to discover a number of potent and selective cyclic peptide inhibitors of human FXIIa. The most promising inhibitors were head-to-tail cyclic peptides 1, 2, 3, and 5, which exhibited nanomolar $\mathrm{IC}_{50}$ values against FXIIa and were 
selective over related coagulation proteases and other common serine proteases. The lead cyclic peptides from the mRNA display (1, 2, 3, and 5) all provided significant prolongation of aPTT at a concentration of $12.5 \mu \mathrm{M}$, while 1 also extended aPTT at a concentration of $1.25 \mu \mathrm{M}$. Each of the FXIIa inhibitors also potently inhibited thrombin generation following contact activation and $\mathbf{1}$ and $\mathbf{5}$ inhibited release of proinflammatory bradykinin generated through the KKS.

The most potent and selective inhibitors ( 1 and 5 ) possessed a conserved pentapeptide motif (YLRFR in $\mathbf{1}$ and YLRLK in 5) that was hypothesized to be the key active sitebinding region of the inhibitors. To identify whether the highly conserved regions in the initial hits were critical for potency, we systematically replaced each residue in peptide $\mathbf{1}$ for an Ala. This Ala scan confirmed the importance of the YLRFR motif for inhibition with a $>1000$-fold drop in activity observed upon Ala substitution of any of the amino acids within this sequence. A total of 55 analogues of the most potent cyclic peptide inhibitor $\mathbf{1}$ were generated to elucidate key SARs. While substitution of the Phe residue within the pentapeptide sequence of 1 was relatively well tolerated, we did not identify any molecules with improved FXIIa inhibitory activity. Substitution of the Tyr1 within the sequence led to a dramatic loss in inhibitory potency, even when subtle replacements were made. Docking and molecular dynamics simulations were used to rationalize this observation, which suggested that the Tyr residue occupies the core of the cyclic peptide and is important for stabilizing the active conformation of the cyclic peptide through the phenolic functionality on the side chain of Tyr. Finally, analogues that possessed substitution of Arg3 and Arg5 within the pentapeptide showed that both the length of the side chain and the guanidinium functionality were important for inhibitory activity.

The inability to discover a more potent FXIIa inhibitor than 1 through the generation of this large library of structural analogues highlights the power of the RaPID mRNA display technology to identify ligands that are already highly optimized to a given protein, consistent with a recent mutational scanning study performed on another target. ${ }^{39}$ Nonetheless, the important SAR that we have established, together with the molecular dynamics studies, should prove useful for future FXIIa inhibitor design. Indeed, we anticipate that this information can now be used for the discovery of nonpeptidic FXIIa inhibitors for potential use against thrombotic and inflammatory disorders in which FXIIa plays a crucial physiological role. Work toward this end is currently underway in our laboratories.

\section{EXPERIMENTAL SECTION}

Chemistry. General Information. Peptide-grade N,N-dimethylformamide (DMF) and dichloromethane $\left(\mathrm{CH}_{2} \mathrm{Cl}_{2}\right)$ were purchased from RCI Labscan and Merck, respectively. Acetonitrile ( $\mathrm{MeCN}$ ) for chromatography was purchased as "gradient grade" from SigmaAldrich and ultrapure water was from a Merck Millipore Direct-Q 5 water purification system. All solvents for chromatography were supplemented with formic acid (FA) purchased from Sigma-Aldrich. All standard Fmoc-protected amino acids and Rink amide resins for peptide synthesis were purchased from Mimotopes. Automated SPPS was carried out on Biotage Syro1. Pooled human plasma was purchased from Sigma-Aldrich.

RaPID Protocol. Cyanomethyl ester (CME)-activated L-Tyr was synthesized as previously described. ${ }^{40}$ Flexizyme aminoacylating ribozymes and tRNAs were prepared by in vitro transcription from PCR-generated DNA templates (see the Supporting Information for oligonucleotide sequences), and aminoacylation of tRNAs using CME-activated amino acids was performed as previously described. ${ }^{33}$ RNA libraries of 7-15 NNK codons were prepared as previously described. ${ }^{40}$ Briefly, RNA molecules were synthesized by T7 RNA polymerase reactions from DNA templates assembled by PCR and purified by PAGE. tRNA aminoacylation was performed in reactions containing $40 \mathrm{mM}$ each tRNA substrate and flexizyme aminoacylating ribozyme, $600 \mathrm{mM} \mathrm{MgCl} 2,5 \mathrm{mM}$ activated amino acid substrate, and $100 \mathrm{mM}$ HEPES-KOH $(\mathrm{pH} 7.5)$ on ice for $2 \mathrm{~h}$ before recovery by precipitation with sodium acetate and ethanol. Puromycin-linked mRNA was prepared by incubation with puromycin-linked oligonucleotide (see the Supporting Information for oligonucleotide sequences) and T4 RNA ligase and was purified by phenol/ chloroform extraction and ethanol precipitation.

Ribosomal synthesis of the macrocyclic peptide libraries was performed as previously described. ${ }^{40}$ In brief, for the initial selection, $1.2 \mathrm{mM}$ puromycin-linked mRNA library was translated in a Metdeficient FIT reaction containing $25 \mathrm{mM}$ of L-ClAc-Tyr-tRNA $\mathrm{fMet}_{\mathrm{for}}$ for $30 \mathrm{~min}$ at $37{ }^{\circ} \mathrm{C}$. The reaction was incubated at $25^{\circ} \mathrm{C}$ for $12 \mathrm{~min}$ before disruption of the ribosome-mRNA complex by incubation at $37{ }^{\circ} \mathrm{C}$ for $30 \mathrm{~min}$ in the presence of $20 \mathrm{mM}$ EDTA. The resulting peptide-linked mRNAs were then reverse-transcribed using RNase $\mathrm{H}$ reverse transcriptase (Promega) for $1 \mathrm{~h}$ at $42{ }^{\circ} \mathrm{C}$. Affinity screening was performed by three serial passages (counterselections, $30 \mathrm{~min}$ each at $4{ }^{\circ} \mathrm{C}$ ) of the library over Dynabeads M-280 Streptavidin (Life Technologies), followed by affinity selection against $200 \mathrm{nM}$ biotinylated human factor $\beta$ XIIa (Molecular Innovations) immobilized on the same beads for $30 \mathrm{~min}$ at $4{ }^{\circ} \mathrm{C}$. cDNA was eluted from the beads by heating to $95{ }^{\circ} \mathrm{C}$ for $5 \mathrm{~min}$ and fractional recovery from the final counterselection (negative control) and affinity selection step were assessed by quantitative PCR using Sybr Green I on a LightCycler thermal cycler (Roche). Enriched DNA libraries were recovered by PCR and used as input for transcription reactions to generate the mRNA library for the subsequent round of screening.

For high-throughput sequencing of the focused selections, DNA samples were PCR-amplified with nesting primers (see the Supporting Information for oligonucleotide sequences), purified using a Nucleospin column (Machery-Nagel), and sequenced using a MiSeq high-throughput sequencer (Illumina). Data analysis was performed using CLC sequence viewer 8 software (Qiagen).

General Synthetic Procedures. Fmoc-SPPS. Rink amide resin (Mimotopes), ( $82 \mathrm{mg}, 50 \mu \mathrm{mol}, 0.61 \mathrm{mmolg}^{-1}, 1$ equiv) was treated with 40 vol \% piperidine $(1.6 \mathrm{~mL})$ in DMF for $4 \mathrm{~min}$, drained, and then treated with 20 vol \% piperidine in DMF for $12 \mathrm{~min}(1.6 \mathrm{~mL})$, drained, and washed with DMF $(4 \times 1.6 \mathrm{~mL})$. The resin was then treated with a solution of Fmoc-Xaa-OH $(400 \mu \mathrm{mol}, 4$ equiv $)$ and Oxyma ( $57 \mathrm{mg}, 400 \mu \mathrm{mol}, 4$ equiv) in DMF ( $800 \mu \mathrm{L})$, followed by a solution of DIC ( $63 \mu \mathrm{L}, 400 \mu \mathrm{mol}, 4$ equiv) in DMF $(800 \mu \mathrm{L})$, and shaken at $75{ }^{\circ} \mathrm{C}$ for $30 \mathrm{~min}$. The resin was then drained and washed with DMF $(4 \times 1.6 \mathrm{~mL})$ before being treated with a solution of $5 \mathrm{vol}$ $\% \mathrm{Ac}_{2} \mathrm{O}$ and 10 vol \% $i \mathrm{Pr}_{2} \mathrm{NEt}$ in $\mathrm{DMF}(1.6 \mathrm{~mL})$ for $5 \mathrm{~min}$ at $\mathrm{rt}$, drained, washed with DMF $(4 \times 1.6 \mathrm{~mL})$, and drained again. These deprotection and coupling steps were repeated for additional amino acids until the target polypeptide was assembled.

Chloroacetic Acid Coupling. The fully elongated resin-bound peptide $(0.05 \mathrm{mmol})$ was shaken in a solution of chloroacetic acid (8 equiv, $0.5 \mathrm{M}$ ), DIC (8 equiv, $125 \mu \mathrm{L}, 0.2 \mathrm{M}$ ), and Oxyma (8 equiv, $0.5 \mathrm{M})$ in DMF $(4 \mathrm{~mL})$ for $15 \mathrm{~min}$ at $75^{\circ} \mathrm{C}$. The coupling solution was dispensed, and the resin was washed with DMF $(3 \times 4 \mathrm{~mL})$ and $\mathrm{CH}_{2} \mathrm{Cl}_{2}(5 \times 4 \mathrm{~mL})$.

Peptide Cleavage from Resin. The resin-bound peptide was shaken in a cleavage solution of trifluoroacetic acid (TFA) $/ i \mathrm{Pr}_{3} \mathrm{SiH} /$ $\mathrm{H}_{2} \mathrm{O}(90: 5: 5 \mathrm{v} / \mathrm{v} / \mathrm{v})$ for $2 \mathrm{~h}$ at $\mathrm{rt}$. The crude product was dispensed, and the resin was rinsed with cleavage cocktail $(\sim 2 \mathrm{~mL})$. These solutions were combined and concentrated to $<1 \mathrm{~mL}$ under a nitrogen flow. To precipitate the free peptide, $\mathrm{Et}_{2} \mathrm{O}(14 \mathrm{~mL})$ was added to the crude concentrate. The resultant suspension was centrifuged for $4 \mathrm{~min}$ at $7000 \mathrm{~g}$ to pellet the free peptide. The supernatant was then decanted, and the precipitation process was repeated once more. The 
crude peptide was dried under a nitrogen flow and then re-dissolved in $1: 1 \mathrm{v} / \mathrm{v} \mathrm{CH}{ }_{3} \mathrm{CN}: \mathrm{H}_{2} \mathrm{O}(\sim 6 \mathrm{~mL})$ for cyclization.

Linear Peptide Cyclization. To a solution of linear peptide $1: 1 \mathrm{v} / \mathrm{v}$ $\mathrm{CH}_{3} \mathrm{CN}: \mathrm{H}_{2} \mathrm{O}(\sim 6 \mathrm{~mL})$, Hünig's base $(300 \mu \mathrm{L}, 0.3 \mathrm{M})$ was added and the reaction was shaken for $2 \mathrm{~h}$ at $\mathrm{rt}$. The cyclic peptide solution was then reacidified with TFA $(240 \mu \mathrm{L}, 0.5 \mathrm{M})$ and filtered in preparation for purification.

Preparative Chromatography. Reversed-phase high-performance liquid chromatography (RP-HPLC) was performed on a Waters 600E multisolvent delivery system fitted with a Rheodyne $7725 \mathrm{i}$ injection valve ( $5 \mathrm{~mL}$ loading loop), a Waters 500 pump, and a Waters $490 \mathrm{E}$ programmable wavelength detector operating at 214 and $230 \mathrm{~nm}$. Preparative reversed-phase HPLC was performed using a Waters Sunfire C18 column $(5 \mu \mathrm{m}, 30 \mathrm{~mm} \times 150 \mathrm{~mm})$ at a flow rate of 38 $\mathrm{mL} \mathrm{min}^{-1}$. All preparative HPLC used a mobile phase of ultrapure (type 1) water (Solvent A) and $\mathrm{MeCN}$ (Solvent B) supplemented with 0.1 vol \% formic acid (FA) or trifluoroacetic acid (TFA) using gradients as specified.

Analytical Chromatography. Liquid chromatography-mass spectrometry (LC-MS) was performed on a Shimadzu 2020 UPLC-MS instrument with a Nexera X2 LC-30AD pump, a Nexera X2 SPDM30A UV-vis diode array detector, and a Shimadzu 2020 (ESI) mass spectrometer operating in either the positive or negative mode. Separations were performed on a Waters Acquity BEH300 $1.7 \mu \mathrm{m}, 2.1$ $\mathrm{mm} \times 50 \mathrm{~mm}(\mathrm{C} 18)$ column at a flow rate of $0.6 \mathrm{~mL} \mathrm{~min}{ }^{-1}$. All separations were performed using a mobile phase of $0.1 \mathrm{vol} \% \mathrm{FA}$ in water (Solvent A) and 0.1 vol \% FA in $\mathrm{MeCN}$ (Solvent B) using gradients as specified. Analytical reversed-phase HPLC was performed on a Waters Acquity UPLC system equipped with a PDA $\lambda$ detector $(\lambda=210-400 \mathrm{~nm})$, a sample manager FAN, and Quaternary Solvent Manager (H-Class) modules. Separations were performed on a Waters Acquity BEH300 $1.7 \mu \mathrm{m}, 2.1 \mathrm{~mm} \times 50 \mathrm{~mm}$ (C18) column at

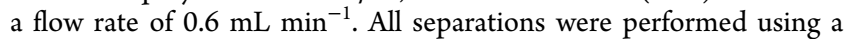
mobile phase of $0.1 \mathrm{vol} \%$ trifluoroacetic acid (TFA) in water (Solvent A) and 0.1 vol \% TFA in $\mathrm{MeCN}$ (Solvent B) using gradients as specified.

Purity Determination. Purity of synthetic cyclic peptides was determined by UPLC analysis. Purity was determined to be $>97 \%$ from the UPLC chromatograms.

Peptide (1) was synthesized via Fmoc-strategy SPPS as specified in general methods. The linear sequence $N^{\prime}$-YLRFRPKDRGGC- $C^{\prime}$ was generated by automated SPPS on the Rink amide resin $(320 \mathrm{mg}, 200$ $\mu$ mol, capacity: $0.61 \mathrm{mmolg}^{-1}$ ). Coupling of chloroacetic acid to the $\mathrm{N}$-terminus, cleavage from the resin, and cyclization were performed as described in the general methods. The crude cyclic peptide was purified by semipreparative RP-HPLC $(0-20 \% \mathrm{~B}+0.1 \%$ formic acid over $40 \mathrm{~min})$. The appropriate fractions were combined and lyophilized to afford 1 as a white solid $(37 \mathrm{mg}, 11 \%)$. UPLC: $R_{t}=$ $3.89 \mathrm{~min}(0-60 \mathrm{vol} \% \mathrm{~B}$ over $5 \mathrm{~min}, 0.1$ vol \% TFA, $\lambda=214 \mathrm{~nm})$. LRMS (ESI+): $m / z=1507.8[\mathrm{M}+\mathrm{H}]^{+}$. ${ }^{1} \mathrm{H}$ NMR $(600 \mathrm{MHz}$, $\left.\mathrm{CD}_{3} \mathrm{CN}: \mathrm{D}_{2} \mathrm{O}\right) \delta 7.25(\mathrm{t}, J=7.4 \mathrm{~Hz}, 2 \mathrm{H}), 7.22-7.17(\mathrm{~m}, 1 \mathrm{H}), 7.15(\mathrm{~d}$, $J=7.5 \mathrm{~Hz}, 2 \mathrm{H}), 7.02(\mathrm{~d}, J=8.6 \mathrm{~Hz}, 2 \mathrm{H}), 6.71(\mathrm{~d}, J=8.4 \mathrm{~Hz}, 2 \mathrm{H})$, $4.58(\mathrm{dd}, J=8.6,5.7 \mathrm{~Hz}, 1 \mathrm{H}), 4.48(\mathrm{dd}, J=9.5,5.5 \mathrm{~Hz}, 1 \mathrm{H}), 4.46-$ $4.40(\mathrm{~m}, 2 \mathrm{H}), 4.38(\mathrm{dd}, J=8.5,6.3 \mathrm{~Hz}, 1 \mathrm{H}), 4.30-4.27(\mathrm{~m}, 1 \mathrm{H})$, $4.22-4.16(\mathrm{~m}, 2 \mathrm{H}), 4.03(\mathrm{dd}, J=8.6,5.6 \mathrm{~Hz}, 1 \mathrm{H}), 3.99(\mathrm{~d}, J=16.9$ $\mathrm{Hz}, 1 \mathrm{H}), 3.94(\mathrm{dd}, J=9.0,5.3 \mathrm{~Hz}, 1 \mathrm{H}), 3.91(\mathrm{~d}, J=17.1 \mathrm{~Hz}, 1 \mathrm{H})$, $3.78(\mathrm{~d}, J=10.0 \mathrm{~Hz}, 1 \mathrm{H}), 3.75(\mathrm{~d}, J=9.7 \mathrm{~Hz}, 1 \mathrm{H}), 3.66-3.61(\mathrm{~m}$, $1 \mathrm{H}), 3.48-3.42(\mathrm{~m}, 1 \mathrm{H}), 3.21(\mathrm{~d}, J=14.9 \mathrm{~Hz}, 1 \mathrm{H}), 3.16-3.00(\mathrm{~m}$, $6 \mathrm{H}), 2.99-2.90(\mathrm{~m}, 3 \mathrm{H}), 2.84(\mathrm{td}, J=11.0,9.4,5.2 \mathrm{~Hz}, 3 \mathrm{H}), 2.61$ (qd, $J=16.5,16.0,6.7 \mathrm{~Hz}, 3 \mathrm{H}), 2.26-2.19(\mathrm{~m}, 2 \mathrm{H}), 1.93-1.82(\mathrm{~m}$, $4 \mathrm{H}), 1.69$ (dddd, $J=28.5,23.8,17.1,9.9 \mathrm{~Hz}, 4 \mathrm{H}), 1.61-1.21(\mathrm{~m}$, $16 \mathrm{H}), 0.83(\mathrm{~d}, J=6.6 \mathrm{~Hz}, 3 \mathrm{H}), 0.78(\mathrm{~d}, J=6.5 \mathrm{~Hz}, 3 \mathrm{H})$. HRMS (ESI $+): m / z$ calcd for $\mathrm{C}_{66} \mathrm{H}_{103} \mathrm{~N}_{23} \mathrm{O}_{16} \mathrm{~S}[\mathrm{M}+3 \mathrm{H}]^{3+}$ 502.9297, found 502.9293.

Peptide (2) was synthesized via Fmoc-strategy SPPS as specified in general methods. The linear sequence $N^{\prime}$-YLRFKHISLGGC- $C^{\prime}$ was generated by automated SPPS on Rink amide resin $(105 \mathrm{mg}, 50 \mu \mathrm{mol}$, capacity: $\left.0.48 \mathrm{mmolg}^{-1}\right)$. Coupling of chloroacetic acid to the $\mathrm{N}$ terminus, cleavage from the resin, and cyclization were performed as described in the general methods. The crude cyclic peptide was purified by semipreparative RP-HPLC $(0-30 \%$ B $+0.1 \%$ formic acid over $40 \mathrm{~min})$. The appropriate fractions were combined and lyophilized to afford 2 as a white solid (12 mg, 15\%). UPLC: $R_{t}=$ $4.03 \mathrm{~min}(0-60 \mathrm{vol} \% \mathrm{~B}$ over $5 \mathrm{~min}, 0.1 \mathrm{vol} \% \mathrm{TFA}, \lambda=214 \mathrm{~nm})$. LRMS (ESI+): $m / z=717.5[\mathrm{M}+2 \mathrm{H}]^{+}$. ${ }^{1} \mathrm{H}$ NMR $(500 \mathrm{MHz}$, $\left.\mathrm{CD}_{3} \mathrm{CN}: \mathrm{D}_{2} \mathrm{O}\right) \delta 8.00(\mathrm{~s}, 1 \mathrm{H}), 7.39(\mathrm{t}, J=7.0 \mathrm{~Hz}, 2 \mathrm{H}), 7.37-7.31(\mathrm{~m}$, $1 \mathrm{H}), 7.28(\mathrm{~d}, J=7.4 \mathrm{~Hz}, 2 \mathrm{H}), 7.19-7.04(\mathrm{~m}, 3 \mathrm{H}), 6.83(\mathrm{~d}, J=8.2$ $\mathrm{Hz}, 2 \mathrm{H}), 4.68-4.57(\mathrm{~m}, 3 \mathrm{H}), 4.55-4.49(\mathrm{~m}, 2 \mathrm{H}), 4.47-4.40(\mathrm{~m}$, $1 \mathrm{H}), 4.31(\mathrm{dd}, J=10.1,4.1 \mathrm{~Hz}, 1 \mathrm{H}), 4.22(\mathrm{~d}, J=7.1 \mathrm{~Hz}, 1 \mathrm{H}), 4.20-$ $4.10(\mathrm{~m}, 2 \mathrm{H}), 4.07-3.92(\mathrm{~m}, 4 \mathrm{H}), 3.92-3.84(\mathrm{~m}, 2 \mathrm{H}), 3.33(\mathrm{~s}, 2 \mathrm{H})$, $3.28-2.94(\mathrm{~m}, 10 \mathrm{H}), 2.91(\mathrm{dd}, J=14.0,4.9 \mathrm{~Hz}, 1 \mathrm{H}), 2.80(\mathrm{dd}, J=$ $14.0,8.6 \mathrm{~Hz}, 1 \mathrm{H}), 1.91-1.57(\mathrm{~m}, 11 \mathrm{H}), 1.53-1.22(\mathrm{~m}, 7 \mathrm{H}), 1.09(\mathrm{dt}$, $J=14.3,7.6 \mathrm{~Hz}, 1 \mathrm{H}), 0.99-0.80(\mathrm{~m}, 18 \mathrm{H})$. HRMS (ESI +$): m / z$ calcd for $\mathrm{C}_{66} \mathrm{H}_{101} \mathrm{~N}_{19} \mathrm{O}_{15} \mathrm{~S}_{1}[\mathrm{M}+2 \mathrm{H}]^{2+} 716.8790$, found 716.8795 .

Peptide (3) was synthesized via Fmoc-strategy SPPS as specified in general methods. The linear sequence $N^{\prime}$-YLRFTYCRRAPNS- $C^{\prime}$ was generated by automated SPPS on the Rink amide resin $(205 \mathrm{mg}, 100$ $\mu \mathrm{mol}$, capacity: $\left.0.48 \mathrm{mmolg}^{-1}\right)$. Coupling of chloroacetic acid to the $\mathrm{N}$-terminus, cleavage from the resin, and cyclization were performed as described in the general methods. The crude cyclic peptide was purified by semipreparative RP-HPLC $(0-30 \% \mathrm{~B}+0.1 \%$ formic acid over $40 \mathrm{~min})$. The appropriate fractions were combined and lyophilized to afford 3 as a white solid $(15 \mathrm{mg}, 8 \%)$. UPLC: $R_{t}=$ $4.10 \mathrm{~min}(0-60 \mathrm{vol} \% \mathrm{~B}$ over $5 \mathrm{~min}, 0.1 \mathrm{vol} \% \mathrm{TFA}, \lambda=214 \mathrm{~nm})$. LRMS (ESI+): $m / z=1636.9[\mathrm{M}+2 \mathrm{H}]^{+}$. HRMS (ESI + ): $m / z$ calcd for $\mathrm{C}_{72} \mathrm{H}_{114} \mathrm{~N}_{24} \mathrm{O}_{18} \mathrm{~S}_{1}[\mathrm{M}+2 \mathrm{H}]^{2+} 818.4298$, found 818.4305.

Peptide (4) was synthesized via Fmoc-strategy SPPS as specified in general methods. The linear sequence $N^{\prime}$-YLICVSRRAFFTDQS- $C^{\prime}$ was generated by automated SPPS on the Rink amide resin $(205 \mathrm{mg}$, $100 \mu \mathrm{mol}$, capacity: $\left.0.48 \mathrm{mmolg}^{-1}\right)$. Coupling of chloroacetic acid to the $\mathrm{N}$-terminus, cleavage from the resin, and cyclization were performed as described in the general methods. The crude cyclic peptide was purified by semipreparative RP-HPLC $(0-30 \%$ B + 0.1\% formic acid over $40 \mathrm{~min}$ ). The appropriate fractions were combined and lyophilized to afford 4 as a white solid ( $22 \mathrm{mg}, 11 \%)$. UPLC: $R_{t}=$ $3.52 \mathrm{~min}(0-60 \mathrm{vol} \% \mathrm{~B}$ over $5 \mathrm{~min}, 0.1 \mathrm{vol} \%$ TFA, $\lambda=214 \mathrm{~nm})$. LRMS (ESI+): $m / z=1846.0[\mathrm{M}+\mathrm{H}]^{+}$. HRMS (ESI+): $\mathrm{m} / z$ calcd for $\mathrm{C}_{83} \mathrm{H}_{125} \mathrm{~N}_{23} \mathrm{O}_{23} \mathrm{~S}_{1}[\mathrm{M}+2 \mathrm{H}]^{2+}$ 922.9582, found 922.9592 .

Peptide (5) was synthesized via Fmoc-strategy SPPS as specified in general methods. The linear sequence $N^{\prime}$-YLRLKPTNQGGC- $C^{\prime}$ was generated by automated SPPS on the Rink amide resin $(357 \mathrm{mg}$, $217.8 \mu \mathrm{mol}$, capacity: $\left.0.61 \mathrm{mmolg}^{-1}\right)$. Coupling of chloroacetic acid to the $\mathrm{N}$-terminus, cleavage from the resin, and cyclization were performed as described in the general methods. A portion of the crude cyclic peptide (161 $\mu \mathrm{mol}$ based on the original resin loading) was purified by semipreparative RP-HPLC $(0-30 \% \mathrm{~B}+0.1 \%$ TFA over $60 \mathrm{~min})$. The appropriate fractions were combined and lyophilized to afford 5 as a white solid $(63 \mathrm{mg}, 24 \%)$. UPLC: $R_{t}=3.52 \mathrm{~min}(0-40$ vol \% B over $5 \mathrm{~min}, 0.1$ vol \% TFA, $\lambda=214 \mathrm{~nm}$ ). LRMS (ESI +$): \mathrm{m} / z$ $=1389.4[\mathrm{M}+\mathrm{H}]^{+} .{ }^{1} \mathrm{H}$ NMR $\left(500 \mathrm{MHz}, \mathrm{CD}_{3} \mathrm{CN}\right) \delta 8.09(\mathrm{~d}, J=6.8$ $\mathrm{Hz}, 1 \mathrm{H}), 8.03-7.97(\mathrm{~m}, 2 \mathrm{H}), 7.95(\mathrm{~d}, J=6.9 \mathrm{~Hz}, 1 \mathrm{H}), 7.92(\mathrm{~d}, J=$ $5.9 \mathrm{~Hz}, 1 \mathrm{H}), 7.82-7.76(\mathrm{~m}, 2 \mathrm{H}), 7.72(\mathrm{~d}, J=7.5 \mathrm{~Hz}, 1 \mathrm{H}), 7.70(\mathrm{~d}, J$ $=7.3 \mathrm{~Hz}, 1 \mathrm{H}), 7.56(\mathrm{~s}, 1 \mathrm{H}), 7.43-7.31(\mathrm{~m}, 3 \mathrm{H}), 7.27(\mathrm{~s}, 1 \mathrm{H}), 7.09(\mathrm{t}$, $J=5.7 \mathrm{~Hz}, 1 \mathrm{H}), 7.02(\mathrm{~d}, J=8.2 \mathrm{~Hz}, 2 \mathrm{H}), 6.85(\mathrm{~s}, 1 \mathrm{H}), 6.71(\mathrm{~d}, J=$ $8.4 \mathrm{~Hz}, 2 \mathrm{H}), 6.61(\mathrm{~s}, 2 \mathrm{H}), 6.54(\mathrm{~s}, 2 \mathrm{H}), 4.62-3.73(\mathrm{~m}, 14 \mathrm{H}), 3.73-$ $3.66(\mathrm{~m}, 1 \mathrm{H}), 3.54-3.46(\mathrm{~m}, 1 \mathrm{H}), 3.21(\mathrm{~d}, J=14.8 \mathrm{~Hz}, 1 \mathrm{H}), 3.15(\mathrm{~d}$, $J=14.9 \mathrm{~Hz}, 1 \mathrm{H}), 3.08(\mathrm{q}, J=6.8 \mathrm{~Hz}, 2 \mathrm{H}), 2.95(\mathrm{dd}, J=14.1,6.0 \mathrm{~Hz}$, $1 \mathrm{H}), 2.88-2.79(\mathrm{~m}, 3 \mathrm{H}), 2.76(\mathrm{dd}, J=14.2,5.8 \mathrm{~Hz}, 1 \mathrm{H}), 2.63(\mathrm{dd}, J$ $=13.4,9.1 \mathrm{~Hz}, 1 \mathrm{H}), 2.26-2.13(\mathrm{~m}, 4 \mathrm{H}), 1.96-1.84(\mathrm{~m}, 4 \mathrm{H}), 1.81-$ $1.39(\mathrm{~m}, 16 \mathrm{H}), 1.36-1.21(\mathrm{~m}, 2 \mathrm{H}), 1.11(\mathrm{~d}, J=6.1 \mathrm{~Hz}, 3 \mathrm{H}), 0.86-$ $0.81(\mathrm{~m}, 6 \mathrm{H}), 0.80-0.76(\mathrm{~m}, 6 \mathrm{H})$. HRMS (ESI $): \mathrm{m} / z$ calcd for $\mathrm{C}_{60} \mathrm{H}_{97} \mathrm{~N}_{19} \mathrm{O}_{17} \mathrm{~S}[\mathrm{M}+2 \mathrm{H}]^{2+}$ 694.8588, found 694.8589 .

Peptide (6) was synthesized via Fmoc-strategy SPPS as specified in general methods. The linear sequence $N^{\prime}$-YLRFTLCRYESALS- $C^{\prime}$ was generated by automated SPPS on the Rink amide resin $(102 \mathrm{mg}, 50$ $\mu \mathrm{mol}$, capacity: $0.49 \mathrm{mmolg}^{-1}$ ). Coupling of chloroacetic acid to the $\mathrm{N}$-terminus, cleavage from the resin, and cyclization were performed as described in the general methods. The crude cyclic peptide was purified by semipreparative RP-HPLC $(0-40 \%$ B $+0.1 \%$ TFA over $40 \mathrm{~min})$. The appropriate fractions were combined and lyophilized to 
afford 6 as a white solid $(6 \mathrm{mg}, 6 \%)$. UPLC: $R_{t}=4.55 \mathrm{~min}(0-60 \mathrm{vol}$ $\%$ B over $5 \mathrm{~min}, 0.1$ vol \% TFA, $\lambda=230 \mathrm{~nm}$ ). LRMS (ESI +$): m / z=$ $1762.2[\mathrm{M}+\mathrm{H}]^{+}$. HRMS (ESI+): $m / z$ calcd for $\mathrm{C}_{80} \mathrm{H}_{121} \mathrm{~N}_{21} \mathrm{O}_{22} \mathrm{~S}_{1}[\mathrm{M}$ $+2 \mathrm{H}]^{2+} 880.9421$, found 880.9431 .

Peptide (7) was synthesized via Fmoc-strategy SPPS as specified in general methods. The linear sequence $N^{\prime}$-ALRFRPKDRGGC- $C^{\prime}$ was generated by automated SPPS on the Rink amide resin $(86 \mathrm{mg}, 50$ $\mu \mathrm{mol}$, capacity: $0.58 \mathrm{mmolg}^{-1}$ ). Coupling of chloroacetic acid to the $\mathrm{N}$-terminus, cleavage from the resin, and cyclization were performed as described in the general methods. The crude cyclic peptide was purified by semipreparative RP-HPLC $(0-20 \%$ B $+0.1 \%$ formic acid over $40 \mathrm{~min})$. The appropriate fractions were combined and lyophilized to afford 7 as a white solid $(4.7 \mathrm{mg}, 7 \%)$. UPLC: $R_{t}=$ $4.25 \mathrm{~min}(0-40 \mathrm{vol} \% \mathrm{~B}$ over $5 \mathrm{~min}, 0.1$ vol \% TFA, $\lambda=214 \mathrm{~nm})$. LRMS (ESI+): $m / z=1415.5[\mathrm{M}+\mathrm{H}]^{+}$. HRMS (ESI + ): $m / z$ calcd for $\mathrm{C}_{60} \mathrm{H}_{99} \mathrm{~N}_{23} \mathrm{O}_{15} \mathrm{~S}_{1}[\mathrm{M}+2 \mathrm{H}]^{2+} 707.8779$, found 707.8777.

Peptide (8) was synthesized via Fmoc-strategy SPPS as specified in general methods. The linear sequence $N^{\prime}$-YARFRPKDRGGC-C $C^{\prime}$ was generated by automated SPPS on the Rink amide resin $(82 \mathrm{mg}, 50$ $\mu$ mol, capacity: $0.48 \mathrm{mmolg}^{-1}$ ). Coupling of chloroacetic acid to the $\mathrm{N}$-terminus, cleavage from the resin, and cyclization were performed as described in the general methods. The crude cyclic peptide was purified by semipreparative RP-HPLC $(0-20 \%$ B $+0.1 \%$ TFA acid over $45 \mathrm{~min})$. The appropriate fractions were combined and lyophilized to afford 8 as a white solid (4.35 mg, 11\%). UPLC: $R_{t}$ $=4.03 \mathrm{~min}(0-60 \mathrm{vol} \% \mathrm{~B}$ over $5 \mathrm{~min}, 0.1 \mathrm{vol} \% \mathrm{TFA}, \lambda=214 \mathrm{~nm})$. LRMS (ESI+): $m / z 733.2[\mathrm{M}+2 \mathrm{H}]^{+}$. HRMS (ESI + ): $m / z$ calcd for $\mathrm{C}_{63} \mathrm{H}_{97} \mathrm{~N}_{23} \mathrm{O}_{16} \mathrm{~S}_{1}[\mathrm{M}+3 \mathrm{H}]^{3+} 488.9068$, found 488.9144 .

Peptide (9) was synthesized via Fmoc-strategy SPPS as specified in general methods. The linear sequence $N^{\prime}$-YLAFRPKDRGGC- $C^{\prime}$ was generated by automated SPPS on the Rink amide resin $(325 \mathrm{mg}, 200$ $\mu \mathrm{mol}$, capacity: $\left.0.52 \mathrm{mmolg}^{-1}\right)$. Coupling of chloroacetic acid to the $\mathrm{N}$-terminus, cleavage from the resin, and cyclization were performed as described in the general methods. The crude cyclic peptide was purified by semipreparative RP-HPLC $(10-50 \%$ B $+0.1 \%$ TFA acid over $45 \mathrm{~min})$. The appropriate fractions were combined and lyophilized to afford 9 as a white solid (36 mg, 15\%). UPLC: $R_{t}=$ $8.10 \mathrm{~min}(0-60 \mathrm{vol} \% \mathrm{~B}$ over $15 \mathrm{~min}, 0.1 \mathrm{vol} \% \mathrm{TFA}, \lambda=214 \mathrm{~nm})$. LRMS (ESI+): $\mathrm{m} / z=1421.7$. HRMS (ESI+): $\mathrm{m} / z$ calcd for $\mathrm{C}_{63} \mathrm{H}_{96} \mathrm{~N}_{20} \mathrm{O}_{16} \mathrm{~S}_{1}[\mathrm{M}+2 \mathrm{H}]^{2+} 711.3517$, found 711.3592 .

Peptide (10) was synthesized via Fmoc-strategy SPPS as specified in general methods. The linear sequence $N^{\prime}$-YLRARPKDRGGC- $C^{\prime}$ was generated by automated SPPS on the Rink amide resin $(86 \mathrm{mg}$, $50 \mu \mathrm{mol}$, capacity: $0.58 \mathrm{mmolg}^{-1}$ ). Coupling of chloroacetic acid to the $\mathrm{N}$-terminus, cleavage from the resin, and cyclization were performed as described in the general methods. The crude cyclic peptide was purified by semipreparative RP-HPLC $(0-20 \%$ B + 0.1\% formic acid over $40 \mathrm{~min})$. The appropriate fractions were combined and lyophilized to afford 10 as a white solid (4.7 mg, 7\%). UPLC: $R_{t}$ $=5.51 \mathrm{~min}(0-40 \mathrm{vol} \% \mathrm{~B}$ over $5 \mathrm{~min}, 0.1 \mathrm{vol} \% \mathrm{TFA}, \lambda=214 \mathrm{~nm})$. LRMS (ESI +$): m / z=1431.6[\mathrm{M}+\mathrm{H}]^{+}$. HRMS (ESI +$): m / z$ calcd for $\mathrm{C}_{60} \mathrm{H}_{99} \mathrm{~N}_{23} \mathrm{O}_{16} \mathrm{~S}_{1} \mathrm{Na}_{1}[\mathrm{M}+\mathrm{H}+\mathrm{Na}]^{2+} 726.8663$, found 726.8668 .

Peptide (11) was synthesized via Fmoc-strategy SPPS as specified in general methods. The linear sequence $N^{\prime}$-YLRFAPKDRGGC- $C^{\prime}$ was generated by automated SPPS on the Rink amide resin $(163 \mathrm{mg}$, $100 \mu \mathrm{mol}$, capacity: $0.52 \mathrm{mmolg}^{-1}$ ). Coupling of chloroacetic acid to the $\mathrm{N}$-terminus, cleavage from the resin, and cyclization were performed as described in the general methods. The crude cyclic peptide was purified by semipreparative RP-HPLC (10-50\% B + $0.1 \%$ TFA acid over $45 \mathrm{~min}$ ). The appropriate fractions were combined and lyophilized to afford 11 as a white solid $(14.5 \mathrm{mg}$, 12\%). UPLC: $R_{t}=3.95 \mathrm{~min}(0-60 \mathrm{vol} \% \mathrm{~B}$ over $5 \mathrm{~min}, 0.1 \mathrm{vol} \%$ TFA, $\lambda=214 \mathrm{~nm}$ ). LRMS (ESI+): $m / z=1422.4$. HRMS (ESI+): $m /$ $z$ calcd for $\mathrm{C}_{63} \mathrm{H}_{96} \mathrm{~N}_{20} \mathrm{O}_{16} \mathrm{~S}_{1}[\mathrm{M}+2 \mathrm{H}]^{2+} 711.3517$, found 711.3588 .

Peptide (12) was synthesized via Fmoc-strategy SPPS as specified in general methods. The linear sequence $N^{\prime}$-YLRFRAKDRGGC- $C^{\prime}$ was generated by automated SPPS on the Rink amide resin $(86 \mathrm{mg}$, $50 \mu \mathrm{mol}$, capacity: $\left.0.58 \mathrm{mmolg}^{-1}\right)$. Coupling of chloroacetic acid to the $\mathrm{N}$-terminus, cleavage from the resin, and cyclization were performed as described in the general methods. The crude cyclic peptide was purified by semipreparative RP-HPLC $(0-20 \%$ B + 0.1\% formic acid over $40 \mathrm{~min}$ ). The appropriate fractions were combined and lyophilized to afford 12 as a white solid $\left(4.7 \mathrm{mg}\right.$, 7\%). UPLC: $R_{t}$ $=4.22 \mathrm{~min}$. LRMS (ESI+): $m / z=1481.7[\mathrm{M}+\mathrm{H}]^{+}$. HRMS (ESI+): $m / z$ calcd for $\mathrm{C}_{67} \mathrm{H}_{105} \mathrm{~N}_{23} \mathrm{O}_{14} \mathrm{~S}_{1}[\mathrm{M}+2 \mathrm{H}]^{2+} 741.8988$, found 741.8997.

Peptide (13) was synthesized via Fmoc-strategy SPPS as specified in general methods. The linear sequence $N^{\prime}$-YLRFRPADRGGC- $C^{\prime}$ was generated by automated SPPS on the Rink amide resin $(86 \mathrm{mg}$, $50 \mu \mathrm{mol}$, capacity: $0.58 \mathrm{mmolg}^{-1}$ ). Coupling of chloroacetic acid to the $\mathrm{N}$-terminus, cleavage from the resin, and cyclization were performed as described in the general methods. The crude cyclic peptide was purified by semipreparative RP-HPLC (0-20\% B + 0.1\% formic acid over $40 \mathrm{~min}$ ). The appropriate fractions were combined and lyophilized to afford 13 as a white solid $(4.7 \mathrm{mg}, 7 \%)$. UPLC: $R_{t}$ $=4.68 \mathrm{~min}(0-40 \mathrm{vol} \% \mathrm{~B}$ over $5 \mathrm{~min}, 0.1 \mathrm{vol} \% \mathrm{TFA}, \lambda=214 \mathrm{~nm})$. LRMS (ESI+): $m / z=1450.5[\mathrm{M}+\mathrm{H}]^{+}$. HRMS (ESI+): $\mathrm{m} / z$ calcd for $\mathrm{C}_{63} \mathrm{H}_{96} \mathrm{~N}_{22} \mathrm{O}_{16} \mathrm{~S}_{1}[\mathrm{M}+3 \mathrm{H}]^{3+} 483.9105$, found 483.9102 .

Peptide (14) was synthesized via Fmoc-strategy SPPS as specified in general methods. The linear sequence $N^{\prime}$-YLRFRPKARGGC- $C^{\prime}$ was generated by automated SPPS on the Rink amide resin $(86 \mathrm{mg}$, $50 \mu \mathrm{mol}$, capacity: $0.58 \mathrm{mmolg}^{-1}$ ). Coupling of chloroacetic acid to the $\mathrm{N}$-terminus, cleavage from the resin, and cyclization were performed as described in the general methods. The crude cyclic peptide was purified by semipreparative RP-HPLC $(0-20 \%$ B $+0.1 \%$ formic acid over $40 \mathrm{~min}$ ). The appropriate fractions were combined and lyophilized to afford 14 as a white solid ( $9.9 \mathrm{mg}, 14 \%)$. UPLC: $R_{t}$ $=4.23 \mathrm{~min}(0-70 \mathrm{vol} \% \mathrm{~B}$ over $5 \mathrm{~min}, 0.1 \mathrm{vol} \%$ TFA, $\lambda=214 \mathrm{~nm})$. LRMS (ESI+): $m / z=1463.5[\mathrm{M}+\mathrm{H}]^{+}$. HRMS (ESI+): $m / z$ calcd for $\mathrm{C}_{65} \mathrm{H}_{103} \mathrm{~N}_{23} \mathrm{O}_{14} \mathrm{~S}_{1}[\mathrm{M}+2 \mathrm{H}]^{2+} 731.8961$, found 731.8962 .

Peptide (15) was synthesized via Fmoc-strategy SPPS as specified in general methods. The linear sequence $N^{\prime}$-YLRFRPKDAGGC- $C^{\prime}$ was generated by automated SPPS on the Rink amide resin $(163 \mathrm{mg}$, $100 \mu \mathrm{mol}$, capacity: $\left.0.52 \mathrm{mmolg}^{-1}\right)$. Coupling of chloroacetic acid to the $\mathrm{N}$-terminus, cleavage from the resin, and cyclization were performed as described in the general methods. The crude cyclic peptide was purified by semipreparative RP-HPLC $(10-50 \% \mathrm{~B}+$ $0.1 \%$ TFA acid over $45 \mathrm{~min}$ ). The appropriate fractions were combined and lyophilized to afford 15 as a white solid $(18.13 \mathrm{mg}$, $15 \%)$. UPLC: $R_{t}=4.05 \mathrm{~min}(0-60 \mathrm{vol} \% \mathrm{~B}$ over $5 \mathrm{~min}, 0.1 \mathrm{vol} \%$ TFA, $\lambda=214 \mathrm{~nm}$ ). LRMS (ESI+): $m / z=1422.4$. HRMS (ESI+): $m /$ $z$ calcd for $\mathrm{C}_{63} \mathrm{H}_{96} \mathrm{~N}_{20} \mathrm{O}_{16} \mathrm{~S}_{1}[\mathrm{M}+3 \mathrm{H}]^{3+} 474.5678$, found 474.5750 .

Peptide (16) was synthesized via Fmoc-strategy SPPS as specified in general methods. The linear sequence $N^{\prime}$-YLRFRPKDRAGC- $C^{\prime}$ was generated by automated SPPS on the Rink amide resin $(86 \mathrm{mg}$, $50 \mu \mathrm{mol}$, capacity: $0.58 \mathrm{mmolg}^{-1}$ ). Coupling of chloroacetic acid to the $\mathrm{N}$-terminus, cleavage from the resin, and cyclization were performed as described in the general methods. The crude cyclic peptide was purified by semipreparative RP-HPLC $(0-20 \%$ B + 0.1\% formic acid over $40 \mathrm{~min}$ ). The appropriate fractions were combined and lyophilized to afford 16 as a white solid (10.1 mg, 14\%). UPLC: $R_{t}=4.83 \mathrm{~min}(0-40$ vol $\% \mathrm{~B}$ over $5 \mathrm{~min}, 0.1 \mathrm{vol} \% \mathrm{TFA}, \lambda=214$ nm). LRMS (ESI+): $m / z=1521.4[\mathrm{M}+\mathrm{H}]^{+}$. HRMS (ESI+): $m / z$ calcd for $\mathrm{C}_{67} \mathrm{H}_{105} \mathrm{~N}_{23} \mathrm{O}_{14} \mathrm{~S}_{1}[\mathrm{M}+2 \mathrm{H}]^{2+} 760.8988$, found 760.8987 .

Peptide (17) was synthesized via Fmoc-strategy SPPS as specified in general methods. The linear sequence $N^{\prime}$-YLRFRPKARGAC- $C^{\prime}$ was generated by automated SPPS on the Rink amide resin $(86 \mathrm{mg}$, $50 \mu \mathrm{mol}$, capacity: $0.58 \mathrm{mmolg}^{-1}$ ). Coupling of chloroacetic acid to the $\mathrm{N}$-terminus, cleavage from the resin, and cyclization were performed as described in the general methods. The crude cyclic peptide was purified by semipreparative RP-HPLC $(0-20 \%$ B + 0.1\% formic acid over $40 \mathrm{~min}$ ). The appropriate fractions were combined and lyophilized to afford 17 as a white solid (10.6 mg, 15\%). UPLC: $R_{t}=4.80 \mathrm{~min}(0-40 \mathrm{vol} \% \mathrm{~B}$ over $5 \mathrm{~min}, 0.1 \mathrm{vol} \% \mathrm{TFA}, \lambda=214$ nm). LRMS (ESI+): $m / z=1521.3[\mathrm{M}+\mathrm{H}]^{+}$. HRMS (ESI+): $m / z$ calcd for $\mathrm{C}_{67} \mathrm{H}_{105} \mathrm{~N}_{23} \mathrm{O}_{14} \mathrm{~S}_{1}[\mathrm{M}+2 \mathrm{H}]^{2+} 760.8988$, found 760.8997 .

Peptide (18) was synthesized via Fmoc-strategy SPPS as specified in general methods. The linear sequence $N^{\prime}$-ALRLKPTNQGGC- $C^{\prime}$ was generated by automated SPPS on the Rink amide resin $(150 \mathrm{mg}$, $85.4 \mu \mathrm{mol}$, capacity: $\left.0.57 \mathrm{mmolg}^{-1}\right)$. Coupling of chloroacetic acid to 
the $\mathrm{N}$-terminus, cleavage from the resin, and cyclization were performed as described in the general methods. A portion of the crude cyclic peptide ( $49.3 \mu \mathrm{mol}$ based on the original resin loading) was purified by semipreparative RP-HPLC $(0-20 \%$ B $+0.1 \%$ formic acid over $40 \mathrm{~min})$. The appropriate fractions were combined and lyophilized to afford 18 as a white solid $(13.6 \mathrm{mg}, 20 \%)$ UPLC: $R_{t}=$ $3.82 \mathrm{~min}$. LRMS (ESI+): $m / z=1296.7[\mathrm{M}+\mathrm{H}]^{+}$. HRMS (ESI+): $m / z$ calcd for $\mathrm{C}_{54} \mathrm{H}_{93} \mathrm{~N}_{19} \mathrm{O}_{16} \mathrm{~S}[\mathrm{M}+2 \mathrm{H}]^{2+} 648.8457$, found 648.8458 .

Peptide (19) was synthesized via Fmoc-strategy SPPS as specified in general methods. The linear sequence $N^{\prime}$-YARLKPTNQGGC- $C^{\prime}$ was generated by automated SPPS on the Rink amide resin $(149 \mathrm{mg}$, $84.8 \mu \mathrm{mol}$, capacity: $0.57 \mathrm{mmolg}^{-1}$ ). Coupling of chloroacetic acid to the $\mathrm{N}$-terminus, cleavage from the resin, and cyclization were performed as described in the general methods. A portion of the crude cyclic peptide $(33.9 \mu \mathrm{mol}$ based on the original loading) was purified by semipreparative RP-HPLC $(0-20 \%$ B $+0.1 \%$ over 40 $\mathrm{min})$. The appropriate fractions were combined and lyophilized to afford 19 as a white solid $(6.0 \mathrm{mg}, 12 \%)$. UPLC: $R_{t}=3.61 \mathrm{~min}$. LRMS (ESI+): $m / z=1346.6[\mathrm{M}+\mathrm{H}]^{+}$. HRMS (ESI +$): m / z$ calcd for $\mathrm{C}_{57} \mathrm{H}_{91} \mathrm{~N}_{19} \mathrm{O}_{17} \mathrm{~S}[\mathrm{M}+2 \mathrm{H}]^{2+}$ 673.83533, found 673.8355 .

Peptide (20) was synthesized via Fmoc-strategy SPPS as specified in general methods. The linear sequence $N^{\prime}$-YLALKPTNQGGC- $C^{\prime}$ was generated by automated SPPS on the Rink amide resin $(149 \mathrm{mg}$, $84.8 \mu \mathrm{mol}$, capacity: $0.57 \mathrm{mmolg}^{-1}$ ). Coupling of chloroacetic acid to the $\mathrm{N}$-terminus, cleavage from the resin, and cyclization were performed as described in the general methods. A portion of the crude cyclic peptide $(34.2 \mu \mathrm{mol}$ based on the original loading) was purified by semipreparative RP-HPLC $(0-20 \%$ B $+0.1 \%$ over 40 $\mathrm{min})$. The appropriate fractions were combined and lyophilized to afford 20 as a white solid $(10.5 \mathrm{mg}, 23 \%)$. UPLC: $R_{t}=4.26 \mathrm{~min}$. LRMS (ESI+): $m / z=1304.8[\mathrm{M}+\mathrm{H}]^{+}$. HRMS (ESI +$): m / z$ calcd for $\mathrm{C}_{57} \mathrm{H}_{90} \mathrm{~N}_{16} \mathrm{O}_{17} \mathrm{~S}[\mathrm{M}+2 \mathrm{H}]^{2+} 652.3268$, found 652.3269 .

Peptide (21) was synthesized via Fmoc-strategy SPPS as specified in general methods. The linear sequence $N^{\prime}$-YLRAKPTNQGGC- $C^{\prime}$ was generated by automated SPPS on the Rink amide resin $(151 \mathrm{mg}$, $86.0 \mu \mathrm{mol}$, capacity: $0.57 \mathrm{mmolg}^{-1}$ ). Coupling of chloroacetic acid to the $\mathrm{N}$-terminus, cleavage from the resin, and cyclization were performed as described in the general methods. A portion of the crude cyclic peptide $(36.1 \mu \mathrm{mol}$ based on the original loading) was purified by semipreparative RP-HPLC $(0-20 \%$ B $+0.1 \%$ formic acid over $40 \mathrm{~min})$. The appropriate fractions were combined and lyophilized to afford 21 as a white solid $(8.7 \mathrm{mg}, 17 \%)$. UPLC: $R_{t}$ $=3.64 \mathrm{~min}$. LRMS (ESI+): $m / z=1347.7[\mathrm{M}+\mathrm{H}]^{+}$. HRMS (ESI+): $m / z$ calcd for $\mathrm{C}_{57} \mathrm{H}_{91} \mathrm{~N}_{19} \mathrm{O}_{17} \mathrm{~S}[\mathrm{M}+2 \mathrm{H}]^{2+} 673.8353$, found 673.8354 .

Peptide (22) was synthesized via Fmoc-strategy SPPS as specified in general methods. The linear sequence $N^{\prime}$-YLRLAPTNQGGC- $C^{\prime}$ was generated by automated SPPS on the Rink amide resin $(172 \mathrm{mg}$, $86.0 \mu \mathrm{mol}$, capacity: $\left.0.57 \mathrm{mmolg}^{-1}\right)$. Coupling of chloroacetic acid to the $\mathrm{N}$-terminus, cleavage from the resin, and cyclization were performed as described in the general methods. A portion of the crude cyclic peptide ( $48.7 \mu \mathrm{mol}$ based on the original loading) was purified by semipreparative RP-HPLC $(0-30 \%$ B $+0.1 \%$ formic acid over $40 \mathrm{~min})$. The appropriate fractions were combined and lyophilized to afford 22 as a white solid (18.3 mg, 27\%). UPLC: $R_{t}$ $=4.42 \mathrm{~min}$. LRMS (ESI +$): m / z=1332.8[\mathrm{M}+\mathrm{H}]^{+}$. HRMS (ESI + ): $m / z$ calcd for $\mathrm{C}_{57} \mathrm{H}_{90} \mathrm{~N}_{18} \mathrm{O}_{17} \mathrm{~S}[\mathrm{M}+2 \mathrm{H}]^{2+}$ 666.3299, found 666.3299.

Peptide (23) was synthesized via Fmoc-strategy SPPS as specified in general methods. The linear sequence $N^{\prime}$-YLRLKATNQGGC- $C^{\prime}$ was generated by automated SPPS on the Rink amide resin $(150 \mathrm{mg}$, $85.2 \mu \mathrm{mol}$, capacity: $0.57 \mathrm{mmolg}^{-1}$ ). Coupling of chloroacetic acid to the $\mathrm{N}$-terminus, cleavage from the resin, and cyclization were performed as described in the general methods. A portion of the crude cyclic peptide ( $34.0 \mu \mathrm{mol}$ based on the original loading) was purified by semipreparative RP-HPLC $(0-20 \%$ B $+0.1 \%$ formic acid over $40 \mathrm{~min})$. The appropriate fractions were combined and lyophilized to afford 23 as a white solid $(4.1 \mathrm{mg}, 8 \%)$. UPLC: $R_{t}=$ $4.03 \mathrm{~min}$. LRMS (ESI+): $m / z=1363.8[\mathrm{M}+\mathrm{H}]^{+}$. HRMS (ESI+): $m / z$ calcd for $\mathrm{C}_{58} \mathrm{H}_{95} \mathrm{~N}_{19} \mathrm{O}_{17} \mathrm{~S}[\mathrm{M}+2 \mathrm{H}]^{2+} 681.8510$, found 681.8510 .

Peptide (24) was synthesized via Fmoc-strategy SPPS as specified in general methods. The linear sequence $N^{\prime}$-YLRLKPANQGGC- $C^{\prime}$ was generated by automated SPPS on the Rink amide resin $(173 \mathrm{mg}$, $98.6 \mu \mathrm{mol}$, capacity: $\left.0.57 \mathrm{mmolg}^{-1}\right)$. Coupling of chloroacetic acid to the $\mathrm{N}$-terminus, cleavage from the resin, and cyclization were performed as described in the general methods. A portion of the crude cyclic peptide ( $46.02 \mu \mathrm{mol}$ based on the original loading) was purified by semipreparative RP-HPLC $(0-20 \%$ B $+0.1 \%$ formic acid over $40 \mathrm{~min})$. The appropriate fractions were combined and lyophilized to afford 24 as a white solid $(21.3 \mathrm{mg}, 32 \%)$. UPLC: $R_{t}$ $=4.09 \mathrm{~min}$. LRMS (ESI+): $m / z=1359.9[\mathrm{M}+\mathrm{H}]^{+}$. HRMS (ESI + ): $m / z$ calcd for $\mathrm{C}_{59} \mathrm{H}_{95} \mathrm{~N}_{19} \mathrm{O}_{16} \mathrm{~S}[\mathrm{M}+2 \mathrm{H}]^{2+} 679.8535$, found 679.8535 .

Peptide (25) was synthesized via Fmoc-strategy SPPS as specified in general methods. The linear sequence $N^{\prime}$-YLRLKPTAQGGC- $C^{\prime}$ was generated by automated SPPS on the Rink amide resin $(179 \mathrm{mg}$, $100.1 \mu \mathrm{mol}$, capacity: $\left.0.57 \mathrm{mmolg}^{-1}\right)$. Coupling of chloroacetic acid to the $\mathrm{N}$-terminus, cleavage from the resin, and cyclization were performed as described in the general methods. A portion of the crude cyclic peptide $(40.0 \mu \mathrm{mol}$ based on the original loading) was purified by semipreparative RP-HPLC $(0-20 \%$ B $+0.1 \%$ formic acid over 40 $\min )$. The appropriate fractions were combined and lyophilized to afford 25 as a white solid (14.2 mg, 24\%). UPLC: $R_{t}=4.14 \mathrm{~min}$. LRMS (ESI+): $m / z=1346.8[\mathrm{M}+\mathrm{H}]^{+}$. HRMS (ESI+): $m / z$ calcd for $\mathrm{C}_{59} \mathrm{H}_{96} \mathrm{~N}_{18} \mathrm{O}_{16} \mathrm{~S}[\mathrm{M}+2 \mathrm{H}]^{2+} 673.3559$, found 673.3559 .

Peptide (26) was synthesized via Fmoc-strategy SPPS as specified in general methods. The linear sequence $N^{\prime}$-YLRLKPTNAGGC- $C^{\prime}$ was generated by automated SPPS on the Rink amide resin $(176 \mathrm{mg}$, $97.8 \mu \mathrm{mol}$, capacity: $0.57 \mathrm{mmolg}^{-1}$ ). Coupling of chloroacetic acid to the $\mathrm{N}$-terminus, cleavage from the resin, and cyclization were performed as described in the general methods. A portion of the crude cyclic peptide $(60.1 \mu \mathrm{mol}$ based on the original loading) was purified by semipreparative RP-HPLC $(0-20 \%$ B $+0.1 \%$ formic acid over $40 \mathrm{~min})$. The appropriate fractions were combined and lyophilized to afford 26 as a white solid $(21.0 \mathrm{mg}, 25 \%$, average of 95\% per step). UPLC: $R_{t}=4.20 \mathrm{~min}$. LRMS (ESI+): $m / z=1332.9$ $[\mathrm{M}+\mathrm{H}]^{+}$. HRMS (ESI +$): m / z$ calcd for $\mathrm{C}_{58} \mathrm{H}_{94} \mathrm{~N}_{18} \mathrm{O}_{16} \mathrm{~S}[\mathrm{M}+2 \mathrm{H}]^{2+}$ 666.3481 , found 666.3484 .

Peptide (27) was synthesized via Fmoc-strategy SPPS as specified in general methods. The linear sequence $N^{\prime}$-YLRLKPTNQAGC- $C^{\prime}$ was generated by automated SPPS on the Rink amide resin $(172 \mathrm{mg}$, $100.4 \mu \mathrm{mol}$, capacity: $\left.0.57 \mathrm{mmolg}^{-1}\right)$. Coupling of chloroacetic acid to the N-terminus, cleavage from the resin, and cyclization were performed as described in the general methods. A portion of the crude cyclic peptide ( $33.5 \mu \mathrm{mol}$ based on the original loading) was purified by semipreparative RP-HPLC ( $0-40 \%$ B $+0.1 \%$ TFA over $60 \mathrm{~min})$. The appropriate fractions were combined and lyophilized to afford 27 as a white solid ( $2.6 \mathrm{mg}, 5 \%$, average of $89 \%$ per step). UPLC: $R_{t}=$ 4.17 min. LRMS (ESI+): $m / z=1403.8[\mathrm{M}+\mathrm{H}]^{+}$. HRMS (ESI+): $m / z$ calcd for $\mathrm{C}_{61} \mathrm{H}_{99} \mathrm{~N}_{19} \mathrm{O}_{17} \mathrm{~S}[\mathrm{M}+2 \mathrm{H}]^{2+} 701.8666$, found 701.8669 .

Peptide (28) was synthesized via Fmoc-strategy SPPS as specified in general methods. The linear sequence $N^{\prime}$-YLRLKPTNQGAC- $C^{\prime}$ was generated by automated SPPS on the Rink amide resin $(176 \mathrm{mg}$, $100.4 \mu \mathrm{mol}$, capacity: $0.57 \mathrm{mmolg}^{-1}$ ). Coupling of chloroacetic acid to the $\mathrm{N}$-terminus, cleavage from the resin, and cyclization were performed as described in the general methods. A portion of the crude cyclic peptide ( $33.5 \mu \mathrm{mol}$ based on the original loading) was purified by semipreparative RP-HPLC $(0-40 \% \mathrm{~B}+0.1 \% \mathrm{TFA}$ over $60 \mathrm{~min})$. The appropriate fractions were combined and lyophilized to afford $\mathbf{2 8}$ as a white solid ( $5.2 \mathrm{mg}, 10 \%)$. UPLC: $R_{t}=4.23 \mathrm{~min}$. LRMS (ESI + ): $m / z=1403.8[\mathrm{M}+\mathrm{H}]^{+}$. HRMS (ESI+): $\mathrm{m} / z$ calcd for $\mathrm{C}_{61} \mathrm{H}_{99} \mathrm{~N}_{19} \mathrm{O}_{17} \mathrm{~S}[\mathrm{M}+2 \mathrm{H}]^{2+} 701.8666$, found 701.8678 .

Peptide (29) was synthesized via Fmoc-strategy SPPS as specified in general methods. The linear sequence $N^{\prime}$-YLRFR- $C^{\prime}$ was generated on the Rink amide resin $\left(82 \mathrm{mg}, 50 \mu \mathrm{mol}\right.$, capacity: $0.52 \mathrm{mmolg}^{-1}$ ) using manual SPPS as described in the general methods. Coupling of chloroacetic acid to the $\mathrm{N}$-terminus was performed as described in the general methods. A $25 \mu \mathrm{mol}$ portion of resin was cleaved as described in the general methods. The crude linear peptide was purified by semipreparative RP-HPLC $(0-30 \%$ B $+0.1 \%$ formic acid over 40 $\mathrm{min})$. The appropriate fractions were combined and lyophilized to afford 29 as a white solid (5.7 mg, 29\%). UPLC: $R_{t}=4.07 \mathrm{~min}(0-60$ vol \% B over $5 \mathrm{~min}, 0.1$ vol \% TFA, $\lambda=214 \mathrm{~nm}$ ). LRMS (ESI +$): m / z$ 
$=795.5[\mathrm{M}+\mathrm{H}]^{+}$. HRMS (ESI +$): m / z$ calcd for $\mathrm{C}_{66} \mathrm{H}_{102} \mathrm{~N}_{24} \mathrm{O}_{18} \mathrm{~S}_{1}$ $[\mathrm{M}+\mathrm{H}]^{+}$795.4624, found 795.4617.

Peptide (30) was synthesized via Fmoc-strategy SPPS as specified in general methods. The linear sequence $N^{\prime}$-YLRFRC- $C^{\prime}$ was generated on the Rink amide resin $(82 \mathrm{mg}, 50 \mu \mathrm{mol}$, capacity: 0.52 $\mathrm{mmolg}^{-1}$ ) using manual SPPS as described in the general methods Coupling of chloroacetic acid to the $\mathrm{N}$-terminus, cleavage from the resin, and cyclization were performed as described in the general methods. The crude cyclic peptide was purified by semipreparative RP-HPLC (0-30\% B $+0.1 \%$ formic acid over $40 \mathrm{~min})$. The appropriate fractions were combined and lyophilized to afford 30 as a white solid (9.4 mg, 21\%). UPLC: $R_{t}=4.09 \mathrm{~min}(0-50 \mathrm{vol} \% \mathrm{~B}$ over $5 \mathrm{~min}, 0.1 \mathrm{vol} \%$ TFA, $\lambda=214 \mathrm{~nm}$ ). LRMS (ESI+): $m / z=896.6[\mathrm{M}$ $+\mathrm{H}]^{+}$. HRMS (ESI+): $m / z$ calcd for $\mathrm{C}_{41} \mathrm{H}_{61} \mathrm{~N}_{13} \mathrm{O}_{8} \mathrm{~S}_{1}[\mathrm{M}+2 \mathrm{H}]^{2+}$ 448.7316, found 448.7314 .

Peptide (31) was synthesized via Fmoc-strategy SPPS as specified in general methods. The linear sequence $N^{\prime}$-YLRFTLC- $C^{\prime}$ was generated on the Rink amide resin $(82 \mathrm{mg}, 50 \mu \mathrm{mol}$, capacity: 0.52 $\mathrm{mmolg}^{-1}$ ) using manual SPPS as described in the general methods. Coupling of chloroacetic acid to the $\mathrm{N}$-terminus, cleavage from the resin, and cyclization were performed as described in the general methods. The crude cyclic peptide was purified by semipreparative RP-HPLC (0-20\% B + 0.1\% formic acid over $40 \mathrm{~min})$. The appropriate fractions were combined and lyophilized to afford 31 as a white solid $(7.7 \mathrm{mg}, 16 \%)$. UPLC: $R_{t}=4.07 \mathrm{~min}(0-40 \mathrm{vol} \% \mathrm{~B}$ over $5 \mathrm{~min}, 0.1$ vol \% TFA, $\lambda=214 \mathrm{~nm}$ ). LRMS (ESI +$): m / z=954.4[\mathrm{M}$ $+\mathrm{H}]^{+}$. HRMS (ESI+): $m / z$ calcd for $\mathrm{C}_{45} \mathrm{H}_{67} \mathrm{~N}_{11} \mathrm{O}_{10} \mathrm{~S}_{1}[\mathrm{M}+\mathrm{H}]^{+}$ 954.4866, found 954.4852 .

Peptide (32) was synthesized via Fmoc-strategy SPPS as specified in general methods. The linear sequence $N^{\prime}$-YLR(2F-Phe)RPKDRGGC- $C^{\prime}$ was generated by automated SPPS on the Rink amide resin $\left(82 \mathrm{mg}, 50 \mu \mathrm{mol}\right.$, capacity: $\left.0.52 \mathrm{mmolg}^{-1}\right)$. Coupling of chloroacetic acid to the $\mathrm{N}$-terminus, cleavage from the resin, and cyclization were performed as described in the general methods. The crude cyclic peptide was purified by semipreparative RP-HPLC (0$20 \%$ B $+0.1 \%$ formic acid over $40 \mathrm{~min}$ ). The appropriate fractions were combined and lyophilized to afford 32 as a white solid $(8.2 \mathrm{mg}$, $11 \%)$. UPLC: $R_{t}=3.87 \mathrm{~min}(0-50 \mathrm{vol} \% \mathrm{~B}$ over $5 \mathrm{~min}, 0.1 \mathrm{vol} \%$ TFA, $\lambda=214 \mathrm{~nm}$ ). LRMS (ESI+): $m / z=1525.3[\mathrm{M}+\mathrm{H}]^{+}$. HRMS (ESI+): $m / z$ calcd for $\mathrm{C}_{66} \mathrm{H}_{102} \mathrm{~F}_{1} \mathrm{~N}_{23} \mathrm{O}_{16} \mathrm{~S}[\mathrm{M}+2 \mathrm{H}]^{2+} 762.8863$, found 762.8857 .

Peptide (33) was synthesized via Fmoc-strategy SPPS as specified in general methods. The linear sequence $N^{\prime}$-YLR(3F-Phe)RPKDRGGC- $C^{\prime}$ was generated by automated SPPS on the Rink amide resin ( $82 \mathrm{mg}, 50 \mu \mathrm{mol}$, capacity: $0.52 \mathrm{mmolg}^{-1}$ ). Coupling of chloroacetic acid to the $\mathrm{N}$-terminus, cleavage from the resin, and cyclization were performed as described in the general methods. The crude cyclic peptide was purified by semipreparative RP-HPLC (0$20 \%$ B $+0.1 \%$ formic acid over $40 \mathrm{~min}$ ). The appropriate fractions were combined and lyophilized to afford 33 as a white solid $(5.8 \mathrm{mg}$, $8 \%)$. UPLC: $R_{t}=4.24 \mathrm{~min}(0-50 \mathrm{vol} \% \mathrm{~B}$ over $5 \mathrm{~min}, 0.1 \mathrm{vol} \% \mathrm{TFA}$, $\lambda=214 \mathrm{~nm}$ ). LRMS (ESI +$): m / z=1525.3[\mathrm{M}+\mathrm{H}]^{+}$. HRMS (ESI $+): m / z$ calcd for $\mathrm{C}_{66} \mathrm{H}_{102} \mathrm{~F}_{1} \mathrm{~N}_{23} \mathrm{O}_{16} \mathrm{~S}[\mathrm{M}+2 \mathrm{H}]^{2+} 762.8863$, found 762.8858 .

Peptide (34) was synthesized via Fmoc-strategy SPPS as specified in general methods. The linear sequence $N^{\prime}$-YLR(4F-Phe)RPKDRGGC-C' $C^{\prime}$ was generated by automated SPPS on the Rink amide resin $\left(82 \mathrm{mg}, 50 \mu \mathrm{mol}\right.$, capacity: $0.52 \mathrm{mmolg}^{-1}$ ). Coupling of chloroacetic acid to the $\mathrm{N}$-terminus, cleavage from the resin, and cyclization were performed as described in the general methods. The crude cyclic peptide was purified by semipreparative RP-HPLC (0$20 \% \mathrm{~B}+0.1 \%$ formic acid over $40 \mathrm{~min})$. The appropriate fractions were combined and lyophilized to afford 34 as a white solid $(7.2 \mathrm{mg}$, 9\%). UPLC: $R_{t}=3.84 \mathrm{~min}(0-40 \mathrm{vol} \% \mathrm{~B}$ over $5 \mathrm{~min}, 0.1 \mathrm{vol} \%$ TFA, $\lambda=214 \mathrm{~nm}$ ). LRMS (ESI +$): m / z=1525.6[\mathrm{M}+\mathrm{H}]^{+}$. HRMS (ESI $+): m / z$ calcd for $\mathrm{C}_{66} \mathrm{H}_{102} \mathrm{~F}_{1} \mathrm{~N}_{23} \mathrm{O}_{16} \mathrm{~S}[\mathrm{M}+2 \mathrm{H}]^{2+} 762.8863$, found 762.8857 .

Peptide (35) was synthesized via Fmoc-strategy SPPS as specified in general methods. The linear sequence $N^{\prime}-\operatorname{YLRF}\left(2 \mathrm{CF}_{3}\right)$ RPKDRGGC-C' $C^{\prime}$ was generated by automated SPPS on the Rink amide resin $\left(82 \mathrm{mg}, 50 \mu \mathrm{mol}\right.$, capacity: $\left.0.53 \mathrm{mmolg}^{-1}\right)$. Coupling of chloroacetic acid to the $\mathrm{N}$-terminus, cleavage from the resin, and cyclization were performed as described in the general methods. The crude cyclic peptide was purified by semipreparative RP-HPLC ( $0-$ $20 \% \mathrm{~B}+0.1 \%$ TFA acid over $45 \mathrm{~min}$ ). The appropriate fractions were combined and lyophilized to afford 35 as a white solid $(8.91 \mathrm{mg}, 8 \%)$. UPLC: $R_{t}=3.98 \mathrm{~min}(0-60 \mathrm{vol} \% \mathrm{~B}$ over $5 \mathrm{~min}, 0.1$ vol $\%$ TFA, $\lambda=$ $214 \mathrm{~nm}$ ). LRMS (ESI+): $m / z=1575.5$. HRMS (ESI +$): m / z$ calcd for $\mathrm{C}_{67} \mathrm{H}_{102} \mathrm{~F}_{3} \mathrm{~N}_{23} \mathrm{O}_{16} \mathrm{~S}_{1}[\mathrm{M}+3 \mathrm{H}]^{3+}$ 525.5849, found 525.5927.

Peptide (36) was synthesized via Fmoc-strategy SPPS as specified in general methods. The linear sequence $N^{\prime}-\operatorname{YLRF}\left(3 \mathrm{CF}_{3}\right)$ RPKDRGGC- $C^{\prime}$ was generated by automated SPPS on the Rink amide resin $\left(82 \mathrm{mg}, 50 \mu \mathrm{mol}\right.$, capacity: $\left.0.53 \mathrm{mmolg}^{-1}\right)$. Coupling of chloroacetic acid to the $\mathrm{N}$-terminus, cleavage from the resin, and cyclization were performed as described in the general methods. The crude cyclic peptide was purified by semipreparative RP-HPLC (0$20 \% \mathrm{~B}+0.1 \%$ TFA acid over $45 \mathrm{~min}$ ). The appropriate fractions were combined and lyophilized to afford 36 as a white solid (5.48 mg, 9\%). UPLC: $R_{t}=4.04 \mathrm{~min}(0-60 \mathrm{vol} \% \mathrm{~B}$ over $5 \mathrm{~min}, 0.1$ vol \% TFA, $\lambda=$ $214 \mathrm{~nm}$ ). LRMS (ESI+): $m / z=1575.5$. HRMS (ESI +$): m / z$ calcd for $\mathrm{C}_{67} \mathrm{H}_{102} \mathrm{~F}_{3} \mathrm{~N}_{23} \mathrm{O}_{16} \mathrm{~S}_{1}[\mathrm{M}+3 \mathrm{H}]^{3+}$ 525.5849, found 525.5928.

Peptide (37) was synthesized via Fmoc-strategy SPPS as specified in general methods. The linear sequence $N^{\prime}-\operatorname{YLRF}\left(4 \mathrm{CF}_{3}\right)$ RPKDRGGC- $C^{\prime}$ was generated by automated SPPS on the Rink amide resin $\left(82 \mathrm{mg}, 50 \mu \mathrm{mol}\right.$, capacity: $\left.0.53 \mathrm{mmolg}^{-1}\right)$. Coupling of chloroacetic acid to the $\mathrm{N}$-terminus, cleavage from the resin, and cyclization were performed as described in the general methods. The crude cyclic peptide was purified by semipreparative RP-HPLC (0$20 \%$ B $+0.1 \%$ TFA acid over $45 \mathrm{~min}$ ). The appropriate fractions were combined and lyophilized to afford 37 as a white solid (3.21 mg, 5\%). UPLC: $R_{t}=3.90 \mathrm{~min}(0-60 \mathrm{vol} \% \mathrm{~B}$ over $5 \mathrm{~min}, 0.1$ vol \% TFA, $\lambda=$ $214 \mathrm{~nm}$ ). LRMS (ESI+): $m / z=1575.6$. HRMS (ESI+): $m / z$ calcd for $\mathrm{C}_{67} \mathrm{H}_{102} \mathrm{~F}_{3} \mathrm{~N}_{23} \mathrm{O}_{16} \mathrm{~S}_{1}[\mathrm{M}+\mathrm{H}+\mathrm{Na}]^{2+}$ 798.8723, found 798.8745 .

Peptide (38) was synthesized via Fmoc-strategy SPPS as specified in general methods. The linear sequence $N^{\prime}-\operatorname{YLRF}(2 \mathrm{CN})$ RPKDRGGC- $C^{\prime}$ was generated by automated SPPS on the Rink amide resin $\left(82 \mathrm{mg}, 50 \mu \mathrm{mol}\right.$, capacity: $0.50 \mathrm{mmolg}^{-1}$ ). Coupling of chloroacetic acid to the $\mathrm{N}$-terminus, cleavage from the resin, and cyclization were performed as described in the general methods. The crude cyclic peptide was purified by semipreparative RP-HPLC (0$20 \% \mathrm{~B}+0.1 \%$ TFA acid over $45 \mathrm{~min}$ ). The appropriate fractions were combined and lyophilized to afford 38 as a white solid $(4.05 \mathrm{mg}, 7 \%)$. UPLC: $R_{t}=3.79 \min (0-60$ vol \% B over $5 \mathrm{~min}, 0.1$ vol \% TFA, $\lambda=$ $214 \mathrm{~nm}$ ). LRMS (ESI+): $m / z=1532.5$. HRMS (ESI +$): m / z$ calcd for $\mathrm{C}_{67} \mathrm{H}_{102} \mathrm{~N}_{24} \mathrm{O}_{16} \mathrm{~S}_{1}[\mathrm{M}+3 \mathrm{H}]^{3+}$ 511.2542, found 511.2617.

Peptide (39) was synthesized via Fmoc-strategy SPPS as specified in general methods. The linear sequence $N^{\prime}-Y \operatorname{LRF}(3 \mathrm{CN})$ RPKDRGGC- $C^{\prime}$ was generated by automated SPPS on the Rink amide resin $\left(82 \mathrm{mg}, 50 \mu \mathrm{mol}\right.$, capacity: $\left.0.50 \mathrm{mmolg}^{-1}\right)$. Coupling of chloroacetic acid to the $\mathrm{N}$-terminus, cleavage from the resin, and cyclization were performed as described in the general methods. The crude cyclic peptide was purified by semipreparative RP-HPLC ( $0-$ $20 \% \mathrm{~B}+0.1 \%$ TFA acid over $45 \mathrm{~min}$ ). The appropriate fractions were combined and lyophilized to afford 39 as a white solid (3.72 $\mathrm{mg}, 6 \%)$. UPLC: $R_{t}=3.80 \mathrm{~min}(0-60 \mathrm{vol} \% \mathrm{~B}$ over $5 \mathrm{~min}, 0.1 \mathrm{vol} \% \mathrm{TFA}, \lambda=$ $214 \mathrm{~nm}$ ). LRMS (ESI+): $m / z=1532.5$. HRMS (ESI +$): m / z$ calcd for $\mathrm{C}_{67} \mathrm{H}_{102} \mathrm{~N}_{24} \mathrm{O}_{16} \mathrm{~S}_{1}[\mathrm{M}+3 \mathrm{H}]^{3+}$ 511.2542, found 511.2616.

Peptide (40) was synthesized via Fmoc-strategy SPPS as specified in general methods. The linear sequence $N^{\prime}-Y L R F(4 C N)$ RPKDRGGC- $C^{\prime}$ was generated by automated SPPS on the Rink amide resin ( $82 \mathrm{mg}, 50 \mu \mathrm{mol}$, capacity: $0.50 \mathrm{mmolg}^{-1}$ ). Coupling of chloroacetic acid to the $\mathrm{N}$-terminus, cleavage from the resin, and cyclization were performed as described in the general methods. The crude cyclic peptide was purified by semipreparative RP-HPLC (0$20 \%$ B $+0.1 \%$ TFA acid over $45 \mathrm{~min}$ ). The appropriate fractions were combined and lyophilized to afford $\mathbf{4 0}$ as a white solid $(6.33 \mathrm{mg}$, $10 \%)$. UPLC: $R_{t}=3.76 \mathrm{~min}(0-60 \mathrm{vol} \% \mathrm{~B}$ over $5 \mathrm{~min}, 0.1 \mathrm{vol} \%$ TFA, $\lambda=214 \mathrm{~nm}$ ). LRMS (ESI +$): m / z=1532.5$. HRMS (ESI +$): m /$ $z$ calcd for $\mathrm{C}_{67} \mathrm{H}_{102} \mathrm{~N}_{24} \mathrm{O}_{16} \mathrm{~S}_{1}[\mathrm{M}+3 \mathrm{H}]^{3+}$ 511.2542, found 511.2620. 
Peptide (41) was synthesized via Fmoc-strategy SPPS as specified in general methods. The linear sequence $N^{\prime}$-YLR(2MePhe)RPKDRGGC- $C^{\prime}$ was generated by automated SPPS on the Rink amide resin $\left(82 \mathrm{mg}, 50 \mu \mathrm{mol}\right.$, capacity: $\left.0.52 \mathrm{mmolg}^{-1}\right)$. Coupling of chloroacetic acid to the $\mathrm{N}$-terminus, cleavage from the resin, and cyclization were performed as described in the general methods. The crude cyclic peptide was purified by semipreparative RP-HPLC (0$20 \% \mathrm{~B}+0.1 \%$ formic acid over $40 \mathrm{~min}$ ). The appropriate fractions were combined and lyophilized to afford 41 as a white solid $(13.1 \mathrm{mg}$, 17\%). UPLC: $R_{t}=4.34 \mathrm{~min}(0-40 \mathrm{vol} \% \mathrm{~B}$ over $5 \mathrm{~min}, 0.1 \mathrm{vol} \%$ TFA, $\lambda=214 \mathrm{~nm}$ ). LRMS (ESI+): $m / z=1521.3[\mathrm{M}+\mathrm{H}]^{+}$. HRMS (ESI+): $m / z$ calcd for $\mathrm{C}_{67} \mathrm{H}_{105} \mathrm{~N}_{23} \mathrm{O}_{16} \mathrm{~S}[\mathrm{M}+3 \mathrm{H}]^{3+} 507.6016$, found 507.6015.

Peptide (42) was synthesized via Fmoc-strategy SPPS as specified in general methods. The linear sequence $N^{\prime}$-YLR(3MePhe)RPKDRGGC- $C^{\prime}$ was generated by automated SPPS on the Rink amide resin $\left(82 \mathrm{mg}, 50 \mu \mathrm{mol}\right.$, capacity: $\left.0.52 \mathrm{mmolg}^{-1}\right)$. Coupling of chloroacetic acid to the $\mathrm{N}$-terminus, cleavage from the resin, and cyclization were performed as described in the general methods. The crude cyclic peptide was purified by semipreparative RP-HPLC (0$20 \%$ B $+0.1 \%$ formic acid over $40 \mathrm{~min}$ ). The appropriate fractions were combined and lyophilized to afford $\mathbf{4 2}$ as a white solid $(9.0 \mathrm{mg}$, $11 \%)$. UPLC: $R_{t}=4.11 \mathrm{~min}(0-50 \mathrm{vol} \% \mathrm{~B}$ over $5 \mathrm{~min}, 0.1 \mathrm{vol} \%$ TFA, $\lambda=214 \mathrm{~nm}$ ). LRMS (ESI+): $m / z=1521.3[\mathrm{M}+\mathrm{H}]^{+}$. HRMS (ESI+): $m / z$ calcd for $\mathrm{C}_{67} \mathrm{H}_{105} \mathrm{~N}_{23} \mathrm{O}_{16} \mathrm{~S}_{1}[\mathrm{M}+3 \mathrm{H}]^{3+} 507.6016$, found 507.6007.

Peptide (43) was synthesized via Fmoc-strategy SPPS as specified in general methods. The linear sequence $N^{\prime}$-YLR(4MePhe)RPKDRGGC- $C^{\prime}$ was generated by automated SPPS on the Rink amide resin $\left(82 \mathrm{mg}, 50 \mu \mathrm{mol}\right.$, capacity: $\left.0.52 \mathrm{mmolg}^{-1}\right)$. Coupling of chloroacetic acid to the $\mathrm{N}$-terminus, cleavage from the resin, and cyclization were performed as described in the general methods. The crude cyclic peptide was purified by semipreparative RP-HPLC (0$20 \%$ B $+0.1 \%$ formic acid over $40 \mathrm{~min}$ ). The appropriate fractions were combined and lyophilized to afford $\mathbf{4 3}$ as a white solid $(7.7 \mathrm{mg}$, 10\%). UPLC: $R_{t}=4.31 \mathrm{~min}(0-40 \mathrm{vol} \% \mathrm{~B}$ over $5 \mathrm{~min}, 0.1 \mathrm{vol} \%$ TFA, $\lambda=214 \mathrm{~nm}$ ). LRMS (ESI +$): m / z=1521.3[\mathrm{M}+\mathrm{H}]^{+}$. HRMS (ESI+): $m / z$ calcd for $\mathrm{C}_{67} \mathrm{H}_{105} \mathrm{~N}_{23} \mathrm{O}_{16} \mathrm{~S}[\mathrm{M}+3 \mathrm{H}]^{3+} 507.6016$, found 507.6011.

Peptide (44) was synthesized via Fmoc-strategy SPPS as specified in general methods. The linear sequence $N^{\prime}$-YLR (2MeOPhe)RPKDRGGC- $C^{\prime}$ was generated by automated SPPS on the Rink amide resin $\left(82 \mathrm{mg}, 50 \mu \mathrm{mol}\right.$, capacity: $\left.0.52 \mathrm{mmolg}^{-1}\right)$. Coupling of chloroacetic acid to the $\mathrm{N}$-terminus, cleavage from the resin, and cyclization were performed as described in the general methods. The crude cyclic peptide was purified by semipreparative RP-HPLC (0$20 \% \mathrm{~B}+0.1 \%$ formic acid over $40 \mathrm{~min})$. The appropriate fractions were combined and lyophilized to afford 44 as a white solid $(7.0 \mathrm{mg}$, 9\%). UPLC: $R_{t}=4.30 \mathrm{~min}(0-50 \mathrm{vol} \% \mathrm{~B}$ over $5 \mathrm{~min}, 0.1 \mathrm{vol} \%$ TFA, $\lambda=214 \mathrm{~nm}$ ). LRMS (ESI +$): m / z=1537.3[\mathrm{M}+\mathrm{H}]^{+}$. HRMS (ESI $+): m / z$ calcd for $\mathrm{C}_{67} \mathrm{H}_{105} \mathrm{~N}_{23} \mathrm{O}_{17} \mathrm{~S}_{1}[\mathrm{M}+2 \mathrm{H}]^{2+} 768.8963$, found 768.8965 .

Peptide (45) was synthesized via Fmoc-strategy SPPS as specified in general methods. The linear sequence $N^{\prime}$-YLR(3MeOPhe)RPKDRGGC- $C^{\prime}$ was generated by automated SPPS on the Rink amide resin $\left(82 \mathrm{mg}, 50 \mu \mathrm{mol}\right.$, capacity: $\left.0.52 \mathrm{mmolg}^{-1}\right)$. Coupling of chloroacetic acid to the $\mathrm{N}$-terminus, cleavage from the resin, and cyclization were performed as described in the general methods. The crude cyclic peptide was purified by semipreparative RP-HPLC (0$20 \%$ B $+0.1 \%$ formic acid over $40 \mathrm{~min}$ ). The appropriate fractions were combined and lyophilized to afford 45 as a white solid $(13 \mathrm{mg}$, $17 \%)$. UPLC: $R_{t}=4.18 \mathrm{~min}(0-50 \mathrm{vol} \% \mathrm{~B}$ over $5 \mathrm{~min}, 0.1$ vol \% TFA, $\lambda=214 \mathrm{~nm}$ ). LRMS (ESI+): $m / z=1537.3[\mathrm{M}+\mathrm{H}]^{+}$. HRMS (ESI+): $m / z$ calcd for $\mathrm{C}_{67} \mathrm{H}_{105} \mathrm{~N}_{23} \mathrm{O}_{17} \mathrm{~S}_{1}[\mathrm{M}+2 \mathrm{H}]^{2+} 768.8963$, found 768.8962.

Peptide (46) was synthesized via Fmoc-strategy SPPS as specified in general methods. The linear sequence $N^{\prime}$-YLR(4MeOPhe)RPKDRGGC- $C^{\prime}$ was generated by automated SPPS on the Rink amide resin $\left(82 \mathrm{mg}, 50 \mu \mathrm{mol}\right.$, capacity: $\left.0.52 \mathrm{mmolg}^{-1}\right)$. Coupling of chloroacetic acid to the $\mathrm{N}$-terminus, cleavage from the resin, and cyclization were performed as described in the general methods. The crude cyclic peptide was purified by semipreparative RP-HPLC (0$20 \% \mathrm{~B}+0.1 \%$ formic acid over $40 \mathrm{~min}$ ). The appropriate fractions were combined and lyophilized to afford 46 as a white solid $(11.5 \mathrm{mg}$, $15 \%)$. UPLC: $R_{t}=4.08 \mathrm{~min}(0-50 \mathrm{vol} \% \mathrm{~B}$ over $5 \mathrm{~min}, 0.1 \mathrm{vol} \%$ TFA, $\lambda=214 \mathrm{~nm}$ ). LRMS (ESI +$): m / z=1537.3[\mathrm{M}+\mathrm{H}]^{+}$. HRMS (ESI+): $m / z$ calcd for $\mathrm{C}_{67} \mathrm{H}_{105} \mathrm{~N}_{23} \mathrm{O}_{17} \mathrm{~S}_{1}[\mathrm{M}+2 \mathrm{H}]^{2+} 768.8963$, found 768.8960 .

Peptide (47) was synthesized via Fmoc-strategy SPPS as specified in general methods. The linear sequence $N^{\prime}$-YLRYRPKDRGGC- $C^{\prime}$ was generated by automated SPPS on the Rink amide resin $(82 \mathrm{mg}$, $50 \mu \mathrm{mol}$, capacity: $\left.0.52 \mathrm{mmolg}^{-1}\right)$. Coupling of chloroacetic acid to the $\mathrm{N}$-terminus, cleavage from the resin, and cyclization were performed as described in the general methods. The crude cyclic peptide was purified by semipreparative RP-HPLC (0-20\% B + 0.1\% formic acid over $40 \mathrm{~min})$. The appropriate fractions were combined and lyophilized to afford 47 as a white solid (11.1 mg, 15\%). UPLC: $R_{t}=4.08 \mathrm{~min}(0-50 \mathrm{vol} \% \mathrm{~B}$ over $5 \mathrm{~min}, 0.1 \mathrm{vol} \% \mathrm{TFA}, \lambda=214$ nm). LRMS (ESI+): $m / z=1523.7[\mathrm{M}+\mathrm{H}]^{+}$. HRMS (ESI+): $m / z$ calcd for $\mathrm{C}_{66} \mathrm{H}_{103} \mathrm{~N}_{23} \mathrm{O}_{17} \mathrm{~S}_{1}[\mathrm{M}+2 \mathrm{H}]^{2+} 761.8884$, found 761.8878 .

Peptide (48) was synthesized via Fmoc-strategy SPPS as specified in general methods. The linear sequence $N^{\prime}$-YLR(2Pal)RPKDRGGC$C^{\prime}$ was generated by automated SPPS on the Rink amide resin (82 $\mathrm{mg}, 50 \mu \mathrm{mol}$, capacity: $0.52 \mathrm{mmolg}^{-1}$ ). Coupling of chloroacetic acid to the $\mathrm{N}$-terminus, cleavage from the resin, and cyclization were performed as described in the general methods. The crude cyclic peptide was purified by semipreparative RP-HPLC $(0-20 \%$ B $+0.1 \%$ formic acid over $40 \mathrm{~min}$ ). The appropriate fractions were combined and lyophilized to afford 48 as a white solid (3.7 mg, 5\%). UPLC: $R_{t}$ $=3.66 \mathrm{~min}(0-40 \mathrm{vol} \% \mathrm{~B}$ over $5 \mathrm{~min}, 0.1 \mathrm{vol} \%$ TFA, $\lambda=214 \mathrm{~nm})$. LRMS (ESI+): $m / z=1508.3[\mathrm{M}+\mathrm{H}]^{+}$. HRMS (ESI+): $m / z$ calcd for $\mathrm{C}_{65} \mathrm{H}_{102} \mathrm{~N}_{24} \mathrm{O}_{16} \mathrm{~S}_{1}[\mathrm{M}+3 \mathrm{H}]^{3+}$ 503.2615, found 503.2608.

Peptide (49) was synthesized via Fmoc-strategy SPPS as specified in general methods. The linear sequence $N^{\prime}$-YLR(3Pal)RPKDRGGC$C^{\prime}$ was generated by automated SPPS on the Rink amide resin (82 $\mathrm{mg}, 50 \mu \mathrm{mol}$, capacity: $0.52 \mathrm{mmolg}^{-1}$ ). Coupling of chloroacetic acid to the $\mathrm{N}$-terminus, cleavage from the resin, and cyclization were performed as described in the general methods. The crude cyclic peptide was purified by semipreparative RP-HPLC $(0-20 \% \mathrm{~B}+0.1 \%$ formic acid over $40 \mathrm{~min}$ ). The appropriate fractions were combined and lyophilized to afford 49 as a white solid ( $4.3 \mathrm{mg}, 6 \%)$. UPLC: $R$ $=3.65 \mathrm{~min}(0-40 \mathrm{vol} \% \mathrm{~B}$ over $5 \mathrm{~min}, 0.1 \mathrm{vol} \% \mathrm{TFA}, \lambda=214 \mathrm{~nm})$. LRMS (ESI+): $m / z=1508.3[\mathrm{M}+\mathrm{H}]^{+}$. HRMS (ESI+): $m / z$ calcd for $\mathrm{C}_{65} \mathrm{H}_{102} \mathrm{~N}_{24} \mathrm{O}_{16} \mathrm{~S}_{1}[\mathrm{M}+2 \mathrm{H}]^{2+} 754.3886$, found 754.3881 .

Peptide (50) was synthesized via Fmoc-strategy SPPS as specified in general methods. The linear sequence $N^{\prime}$-YLR(4Pal)RPKDRGGC$C^{\prime}$ was generated by automated SPPS on the Rink amide resin (82 $\mathrm{mg}, 50 \mu \mathrm{mol}$, capacity: $0.52 \mathrm{mmolg}^{-1}$ ). Coupling of chloroacetic acid to the N-terminus, cleavage from the resin, and cyclization were performed as described in the general methods. The crude cyclic peptide was purified by semipreparative RP-HPLC (0-20\% B + 0.1\% formic acid over $40 \mathrm{~min}$ ). The appropriate fractions were combined and lyophilized to afford $\mathbf{5 0}$ as a white solid (2.4 mg, 3\%). UPLC: $R_{t}$ $=3.42 \mathrm{~min}(0-40 \mathrm{vol} \% \mathrm{~B}$ over $5 \mathrm{~min}, 0.1 \mathrm{vol} \% \mathrm{TFA}, \lambda=214 \mathrm{~nm})$. LRMS (ESI+): $m / z=1508.3[\mathrm{M}+\mathrm{H}]^{+}$.

Peptide (51) was synthesized via Fmoc-strategy SPPS as specified in general methods. The linear sequence $N^{\prime}$-YLR(hY)RPKDRGGC$C^{\prime}$ was generated by automated SPPS on the Rink amide resin (82 $\mathrm{mg}, 50 \mu \mathrm{mol}$, capacity: $0.52 \mathrm{mmolg}^{-1}$ ). Coupling of chloroacetic acid to the $\mathrm{N}$-terminus, cleavage from the resin, and cyclization were performed as described in the general methods. The crude cyclic peptide was purified by semipreparative RP-HPLC $(0-20 \%$ B $+0.1 \%$ formic acid over $40 \mathrm{~min}$ ). The appropriate fractions were combined and lyophilized to afford 51 as a white solid $(4.2 \mathrm{mg}, 5 \%)$. UPLC: $R_{t}$ $=4.39 \mathrm{~min}(0-40 \mathrm{vol} \% \mathrm{~B}$ over $5 \mathrm{~min}, 0.1 \mathrm{vol} \% \mathrm{TFA}, \lambda=214 \mathrm{~nm})$. LRMS (ESI+): $m / z=1537.5[\mathrm{M}+\mathrm{H}]^{+}$. HRMS (ESI+): $m / z$ calcd for $\mathrm{C}_{67} \mathrm{H}_{105} \mathrm{~N}_{23} \mathrm{O}_{16} \mathrm{~S}_{1}[\mathrm{M}+2 \mathrm{H}]^{2+} 768.8963$, found 768.8956 .

Peptide (52) was synthesized via Fmoc-strategy SPPS as specified in general methods. The linear sequence $N^{\prime}$-YLR(hF)RPKDRGGC$C^{\prime}$ was generated by automated SPPS on the Rink amide resin (82 
$\mathrm{mg}, 200 \mu \mathrm{mol}$, capacity: $\left.0.52 \mathrm{mmolg}^{-1}\right)$. Coupling of chloroacetic acid to the $\mathrm{N}$-terminus, cleavage from the resin, and cyclization were performed as described in the general methods. The crude cyclic peptide was purified by semipreparative RP-HPLC $(0-20 \%$ B $+0.1 \%$ formic acid over $40 \mathrm{~min}$ ). The appropriate fractions were combined and lyophilized to afford $\mathbf{5 2}$ as a white solid (3.5 mg, 5\%). UPLC: $R_{t}$ $=4.49 \mathrm{~min}(0-40 \mathrm{vol} \% \mathrm{~B}$ over $5 \mathrm{~min}, 0.1 \mathrm{vol} \% \mathrm{TFA}, \lambda=214 \mathrm{~nm})$. LRMS (ESI+): $m / z=1521.5[\mathrm{M}+\mathrm{H}]^{+}$. HRMS (ESI + ): $m / z$ calcd for $\mathrm{C}_{67} \mathrm{H}_{105} \mathrm{~N}_{23} \mathrm{O}_{16} \mathrm{~S}_{1}[\mathrm{M}+2 \mathrm{H}]^{2+} 760.8988$, found 760.8984 .

Peptide (53) was synthesized via Fmoc-strategy SPPS as specified in general methods. The linear sequence $N^{\prime}-\mathrm{YLR}(3 \mathrm{Nal})$ RPKDRGGC- $C^{\prime}$ was generated by automated SPPS on the Rink amide resin $\left(82 \mathrm{mg}, 50 \mu \mathrm{mol}\right.$, capacity: $\left.0.52 \mathrm{mmolg}^{-1}\right)$. Coupling of chloroacetic acid to the $\mathrm{N}$-terminus, cleavage from the resin, and cyclization were performed as described in the general methods. The crude cyclic peptide was purified by semipreparative RP-HPLC (0$20 \% \mathrm{~B}+0.1 \%$ formic acid over $40 \mathrm{~min}$ ). The appropriate fractions were combined and lyophilized to afford $\mathbf{5 3}$ as a white solid $(13.2 \mathrm{mg}$, 17\%). UPLC: $R_{t}=4.64 \mathrm{~min}(0-50 \mathrm{vol} \% \mathrm{~B}$ over $5 \mathrm{~min}, 0.1 \mathrm{vol} \%$ TFA, $\lambda=214 \mathrm{~nm}$ ). LRMS (ESI+): $m / z=1557.4[\mathrm{M}+\mathrm{H}]^{+}$. HRMS (ESI+): $m / z$ calcd for $\mathrm{C}_{70} \mathrm{H}_{105} \mathrm{~N}_{23} \mathrm{O}_{16} \mathrm{~S}_{1}[\mathrm{M}+2 \mathrm{H}]^{2+} 778.8988$, found 778.8990 .

Peptide (54) was synthesized via Fmoc-strategy SPPS as specified in general methods. The linear sequence $N^{\prime}$-YLR $(2 \mathrm{Nal})$ RPKDRGGC- $C^{\prime}$ was generated by automated SPPS on the Rink amide resin $\left(82 \mathrm{mg}, 50 \mu \mathrm{mol}\right.$, capacity: $\left.0.52 \mathrm{mmolg}^{-1}\right)$. Coupling of chloroacetic acid to the $\mathrm{N}$-terminus, cleavage from the resin, and cyclization were performed as described in the general methods. The crude cyclic peptide was purified by semipreparative RP-HPLC (0$20 \% \mathrm{~B}+0.1 \%$ formic acid over $40 \mathrm{~min}$ ). The appropriate fractions were combined and lyophilized to afford $\mathbf{5 4}$ as a white solid $(11.7 \mathrm{mg}$, $15 \%)$. UPLC: $R_{t}=4.62 \mathrm{~min}(0-50 \mathrm{vol} \% \mathrm{~B}$ over $5 \mathrm{~min}, 0.1 \mathrm{vol} \%$ TFA, $\lambda=214 \mathrm{~nm}$ ). LRMS (ESI+): $m / z=1557.4[\mathrm{M}+\mathrm{H}]^{+}$. HRMS (ESI+): $m / z$ calcd for $\mathrm{C}_{70} \mathrm{H}_{105} \mathrm{~N}_{23} \mathrm{O}_{16} \mathrm{~S}_{1}[\mathrm{M}+2 \mathrm{H}]^{2+} 778.8988$, found 778.8985 .

Peptide (55) was synthesized via Fmoc-strategy SPPS as specified in general methods. The linear sequence $N^{\prime}$-YLR(Thiq)RPKDRGGC- $C^{\prime}$ was generated by automated SPPS on the Rink amide resin $\left(82 \mathrm{mg}, 50 \mu \mathrm{mol}\right.$, capacity: $\left.0.52 \mathrm{mmolg}^{-1}\right)$. Coupling of chloroacetic acid to the $\mathrm{N}$-terminus, cleavage from the resin, and cyclization were performed as described in the general methods. The crude cyclic peptide was purified by semipreparative RP-HPLC (0$20 \% \mathrm{~B}+0.1 \%$ formic acid over $40 \mathrm{~min}$ ). The appropriate fractions were combined and lyophilized to afford $\mathbf{5 5}$ as a white solid $(10.6 \mathrm{mg}$, 14\%). UPLC: $R_{t}=4.90 \mathrm{~min}(0-50 \mathrm{vol} \% \mathrm{~B}$ over $5 \mathrm{~min}, 0.1 \mathrm{vol} \%$ TFA, $\lambda=214 \mathrm{~nm}$ ). LRMS (ESI+): $m / z=1519.7[\mathrm{M}+\mathrm{H}]^{+}$. HRMS (ESI+): $m / z$ calcd for $\mathrm{C}_{67} \mathrm{H}_{103} \mathrm{~N}_{23} \mathrm{O}_{16} \mathrm{~S}_{1}[\mathrm{M}+2 \mathrm{H}]^{2+} 759.8910$, found 759.8910.

Peptide (56) was synthesized via Fmoc-strategy SPPS as specified in general methods. The linear sequence $N^{\prime}$-YLR(Cha)RPKDRGGC$C^{\prime}$ was generated by automated SPPS on the Rink amide resin (82 $\mathrm{mg}, 50 \mu \mathrm{mol}$, capacity: $0.52 \mathrm{mmolg}^{-1}$ ). Coupling of chloroacetic acid to the $\mathrm{N}$-terminus, cleavage from the resin, and cyclization were performed as described in the general methods. The crude cyclic peptide was purified by semipreparative RP-HPLC $(0-20 \%$ B + 0.1\% formic acid over $40 \mathrm{~min})$. The appropriate fractions were combined and lyophilized to afford $\mathbf{5 6}$ as a white solid (9.6 mg, 13\%). UPLC: $R_{t}$ $=4.26$ min. LRMS (ESI+): $m / z=1513.4[\mathrm{M}+\mathrm{H}]^{+}$. HRMS (ESI + ): $m / z$ calcd for $\mathrm{C}_{66} \mathrm{H}_{109} \mathrm{~N}_{23} \mathrm{O}_{16} \mathrm{~S}_{1}[\mathrm{M}+2 \mathrm{H}]^{2+} 756.9144$, found 756.9140 .

Peptide (57) was synthesized via Fmoc-strategy SPPS as specified in general methods. The linear sequence $N^{\prime}$-FLRFRPKDRGGC- $C^{\prime}$ was generated by automated SPPS on the Rink amide resin $(82 \mathrm{mg}$, $50 \mu \mathrm{mol}$, capacity: $\left.0.52 \mathrm{mmolg}^{-1}\right)$. Coupling of chloroacetic acid to the $\mathrm{N}$-terminus, cleavage from the resin, and cyclization were performed as described in the general methods. The crude cyclic peptide was purified by semipreparative RP-HPLC (0-20\% B + 0.1\% formic acid over $40 \mathrm{~min}$ ). The appropriate fractions were combined and lyophilized to afford $\mathbf{5 7}$ as a white solid (9.6 mg, 13\%). UPLC: $R_{t}$ $=4.93 \mathrm{~min}(0-40 \mathrm{vol} \% \mathrm{~B}$ over $5 \mathrm{~min}, 0.1 \mathrm{vol} \%$ TFA, $\lambda=214 \mathrm{~nm})$.
LRMS (ESI+): $m / z=1491.7[\mathrm{M}+\mathrm{H}]^{+}$. HRMS (ESI+): $m / z$ calcd for $\mathrm{C}_{66} \mathrm{H}_{103} \mathrm{~N}_{23} \mathrm{O}_{15} \mathrm{~S}_{1}[\mathrm{M}+3 \mathrm{H}]^{3+}$ 497.5981, found 497.5974.

Peptide (58) was synthesized via Fmoc-strategy SPPS as specified in general methods. The linear sequence $N^{\prime}-\left(2 \mathrm{CF}_{3} \mathrm{Phe}\right)$ LRFRPKDRGGC- $C^{\prime}$ was generated by automated SPPS on the Rink amide resin $\left(82 \mathrm{mg}, 50 \mu \mathrm{mol}\right.$, capacity: $0.52 \mathrm{mmolg}^{-1}$ ). Coupling of chloroacetic acid to the $\mathrm{N}$-terminus, cleavage from the resin, and cyclization were performed as described in the general methods. The crude cyclic peptide was purified by semipreparative RP-HPLC (0-20\% B + 0.1\% formic acid over $40 \mathrm{~min})$. The appropriate fractions were combined and lyophilized to afford $\mathbf{5 8}$ as a white solid (12.4 mg, 16\%). UPLC: $R_{t}=5.62 \mathrm{~min}(0-40$ vol \% B over $5 \mathrm{~min}, 0.1 \mathrm{vol} \%$ TFA, $\lambda=214 \mathrm{~nm}$ ). LRMS (ESI +$): \mathrm{m} / z=$ $1559.3[\mathrm{M}+\mathrm{H}]^{+}$. HRMS (ESI+): $m / z$ calcd for $\mathrm{C}_{67} \mathrm{H}_{102} \mathrm{~F}_{3} \mathrm{~N}_{23} \mathrm{O}_{16} \mathrm{~S}$ $[\mathrm{M}+2 \mathrm{H}]^{2+} 779.8872$, found 779.8887 .

Peptide (59) was synthesized via Fmoc-strategy SPPS as specified in general methods. The linear sequence $N^{\prime}-\left(3 \mathrm{CF}_{3} \mathrm{Phe}\right)$ LRFRPKDRGGC- $C^{\prime}$ was generated by automated SPPS on the Rink amide resin $\left(82 \mathrm{mg}, 50 \mu \mathrm{mol}\right.$, capacity: $\left.0.52 \mathrm{mmolg}^{-1}\right)$. Coupling of chloroacetic acid to the $\mathrm{N}$-terminus, cleavage from the resin, and cyclization were performed as described in the general methods. The crude cyclic peptide was purified by semipreparative RP-HPLC (0-20\% B + 0.1\% formic acid over $40 \mathrm{~min})$. The appropriate fractions were combined and lyophilized to afford $\mathbf{5 9}$ as a white solid (13.0 mg, 17\%). UPLC: $R_{t}=5.37 \mathrm{~min}(0-50$ vol \% B over $5 \mathrm{~min}, 0.1$ vol $\%$ TFA, $\lambda=214 \mathrm{~nm}$ ). LRMS (ESI +$): \mathrm{m} / z=$ $1559.3[\mathrm{M}+\mathrm{H}]^{+}$. HRMS (ESI+): $\mathrm{m} / z$ calcd for $\mathrm{C}_{67} \mathrm{H}_{102} \mathrm{~F}_{3} \mathrm{~N}_{23} \mathrm{O}_{16} \mathrm{~S}$ $[\mathrm{M}+3 \mathrm{H}]^{3+} 520.2606$, found 520.2600 .

Peptide (60) was synthesized via Fmoc-strategy SPPS as specified in general methods. The linear sequence $N^{\prime}-\left(4 \mathrm{CF}_{3} \mathrm{Phe}\right)$ LRFRPKDRGGC- $C^{\prime}$ was generated by automated SPPS on the Rink amide resin $\left(82 \mathrm{mg}, 50 \mu \mathrm{mol}\right.$, capacity: $\left.0.52 \mathrm{mmolg}^{-1}\right)$. Coupling of chloroacetic acid to the $\mathrm{N}$-terminus, cleavage from the resin, and cyclization were performed as described in the general methods. The crude cyclic peptide was purified by semipreparative RP-HPLC (0-20\% B + 0.1\% formic acid over $40 \mathrm{~min})$. The appropriate fractions were combined and lyophilized to afford $\mathbf{6 0}$ as a white solid $(11.0 \mathrm{mg}, 14 \%)$. UPLC: $R_{t}=5.12 \mathrm{~min}(0-50 \mathrm{vol} \% \mathrm{~B}$ over $5 \mathrm{~min}, 0.1$ vol \% TFA, $\lambda=214 \mathrm{~nm}$ ). LRMS (ESI+): $\mathrm{m} / z=$ $1559.3[\mathrm{M}+\mathrm{H}]^{+}$. HRMS (ESI+): $m / z$ calcd for $\mathrm{C}_{67} \mathrm{H}_{102} \mathrm{~F}_{3} \mathrm{~N}_{23} \mathrm{O}_{16} \mathrm{~S}$ $[\mathrm{M}+3 \mathrm{H}]^{3+} 520.2606$, found 520.2599 .

Peptide (61) was synthesized via Fmoc-strategy SPPS as specified in general methods. The linear sequence $N^{\prime}$-(2CNPhe)LRFRPKDRGGC- $C^{\prime}$ was generated by automated SPPS on the Rink amide resin $\left(82 \mathrm{mg}, 50 \mu \mathrm{mol}\right.$, capacity: $\left.0.52 \mathrm{mmolg}^{-1}\right)$. Coupling of chloroacetic acid to the $\mathrm{N}$-terminus, cleavage from the resin, and cyclization were performed as described in the general methods. The crude cyclic peptide was purified by semipreparative RP-HPLC (0-20\% B + 0.1\% formic acid over $40 \mathrm{~min}$ ). The appropriate fractions were combined and lyophilized to afford $\mathbf{6 1}$ as a white solid ( $13 \mathrm{mg}, 17 \%)$. UPLC: $R_{t}=3.92 \mathrm{~min}(0-60 \mathrm{vol} \% \mathrm{~B}$ over $5 \mathrm{~min}, 0.1$ vol \% TFA, $\lambda=214 \mathrm{~nm}$ ). LRMS (ESI+): $m / z=1516.74$ $[\mathrm{M}+\mathrm{H}]^{+}$. HRMS (ESI+): $m / z$ calcd for $\mathrm{C}_{67} \mathrm{H}_{102} \mathrm{~N}_{24} \mathrm{O}_{15} \mathrm{~S}_{1}[\mathrm{M}+$ $2 \mathrm{H}]^{2+} 758.3911$, found 758.3916 .

Peptide (62) was synthesized via Fmoc-strategy SPPS as specified in general methods. The linear sequence $N^{\prime}$-(3CNPhe)LRFRPKDRGGC- $C^{\prime}$ was generated by automated SPPS on the Rink amide resin $\left(82 \mathrm{mg}, 50 \mu \mathrm{mol}\right.$, capacity: $\left.0.52 \mathrm{mmolg}^{-1}\right)$. Coupling of chloroacetic acid to the $\mathrm{N}$-terminus, cleavage from the resin, and cyclization were performed as described in the general methods. The crude cyclic peptide was purified by semipreparative RP-HPLC (0-20\% B + 0.1\% formic acid over $40 \mathrm{~min})$. The appropriate fractions were combined and lyophilized to afford 62 as a white solid (14.2 mg, 19\%). UPLC: $R_{t}=4.99 \mathrm{~min}(0-40 \mathrm{vol} \% \mathrm{~B}$ over $5 \mathrm{~min}, 0.1$ vol \% TFA, $\lambda=214 \mathrm{~nm}$ ). LRMS (ESI+): $\mathrm{m} / z=$ $1516.7[\mathrm{M}+\mathrm{H}]^{+}$. HRMS (ESI+): $m / z$ calcd for $\mathrm{C}_{67} \mathrm{H}_{102} \mathrm{~N}_{24} \mathrm{O}_{15} \mathrm{~S}_{1}[\mathrm{M}$ $+2 \mathrm{H}]^{2+} 758.3911$, found 758.3913 .

Peptide (63) was synthesized via Fmoc-strategy SPPS as specified in general methods. The linear sequence $N^{\prime}$-(4CNPhe)LRFRPKDRGGC- $C^{\prime}$ was generated by automated SPPS on the 
Rink amide resin $\left(82 \mathrm{mg}, 50 \mu \mathrm{mol}\right.$, capacity: $\left.0.52 \mathrm{mmolg}^{-1}\right)$. Coupling of chloroacetic acid to the $\mathrm{N}$-terminus, cleavage from the resin, and cyclization were performed as described in the general methods. The crude cyclic peptide was purified by semipreparative RP-HPLC (0-20\% B + 0.1\% formic acid over $40 \mathrm{~min})$. The appropriate fractions were combined and lyophilized to afford 63 as a white solid (10.4 mg, 14\%). UPLC: $R_{t}=4.92 \mathrm{~min}(0-40 \mathrm{vol} \% \mathrm{~B}$ over $5 \mathrm{~min}, 0.1$ vol \% TFA, $\lambda=214 \mathrm{~nm}$ ). LRMS (ESI+): $\mathrm{m} / z=$ $1516.7[\mathrm{M}+\mathrm{H}]^{+}$. HRMS (ESI + ): $m / z$ calcd for $\mathrm{C}_{67} \mathrm{H}_{102} \mathrm{~N}_{24} \mathrm{O}_{15} \mathrm{~S}_{1}[\mathrm{M}$ $+2 \mathrm{H}]^{2+} 758.3911$, found 758.3908 .

Peptide (64) was synthesized via Fmoc-strategy SPPS as specified in general methods. The linear sequence $N^{\prime}$-(2F-Phe)LRFRPKDRGGC- $C^{\prime}$ was generated by automated SPPS on the Rink amide resin $\left(82 \mathrm{mg}, 50 \mu \mathrm{mol}\right.$, capacity: $\left.0.52 \mathrm{mmolg}^{-1}\right)$. Coupling of chloroacetic acid to the $\mathrm{N}$-terminus, cleavage from the resin, and cyclization were performed as described in the general methods. The crude cyclic peptide was purified by semipreparative RP-HPLC (0-20\% B + 0.1\% formic acid over $40 \mathrm{~min})$. The appropriate fractions were combined and lyophilized to afford 64 as a white solid $(11.5 \mathrm{mg}, 15 \%)$. UPLC: $R_{t}=4.19 \mathrm{~min}(0-50$ vol \% B over $5 \mathrm{~min}, 0.1$ vol \% TFA, $\lambda=214 \mathrm{~nm}$ ). LRMS (ESI+): $\mathrm{m} / z=$ $1509.6[\mathrm{M}+\mathrm{H}]^{+}$. HRMS (ESI+): $m / z$ calcd for $\mathrm{C}_{66} \mathrm{H}_{102} \mathrm{FN}_{23} \mathrm{O}_{15} \mathrm{~S}_{1}$ $[\mathrm{M}+2 \mathrm{H}]^{2+} 754.8888$, found 754.8892 .

Peptide (65) was synthesized via Fmoc-strategy SPPS as specified in general methods. The linear sequence $N^{\prime}$-(3F-Phe)LRFRPKDRGGC- $C^{\prime}$ was generated by automated SPPS on the Rink amide resin $\left(82 \mathrm{mg}, 50 \mu \mathrm{mol}\right.$, capacity: $0.52 \mathrm{mmolg}^{-1}$ ). Coupling of chloroacetic acid to the $\mathrm{N}$-terminus, cleavage from the resin, and cyclization were performed as described in the general methods. The crude cyclic peptide was purified by semipreparative RP-HPLC (0-20\% B + 0.1\% formic acid over $40 \mathrm{~min}$ ). The appropriate fractions were combined and lyophilized to afford $\mathbf{6 5}$ as a white solid ( $8.9 \mathrm{mg}, 12 \%)$. UPLC: $R_{t}=5.02 \mathrm{~min}(0-40 \mathrm{vol} \% \mathrm{~B}$ over $5 \mathrm{~min}, 0.1$ vol \% TFA, $\lambda=214 \mathrm{~nm}$ ). LRMS (ESI +$): m / z=1509.5[\mathrm{M}$ $+\mathrm{H}]^{+}$. HRMS (ESI+): $m / z$ calcd for $\mathrm{C}_{66} \mathrm{H}_{102} \mathrm{FN}_{23} \mathrm{O}_{15} \mathrm{~S}_{1}[\mathrm{M}+2 \mathrm{H}]^{2+}$ 754.8888 , found 754.8888 .

Peptide (66) was synthesized via Fmoc-strategy SPPS as specified in general methods. The linear sequence $N^{\prime}$-(4F-Phe)LRFRPKDRGGC- $C^{\prime}$ was generated by automated SPPS on the Rink amide resin $\left(82 \mathrm{mg}, 50 \mu \mathrm{mol}\right.$, capacity: $0.52 \mathrm{mmolg}^{-1}$ ). Coupling of chloroacetic acid to the $\mathrm{N}$-terminus, cleavage from the resin, and cyclization were performed as described in the general methods. The crude cyclic peptide was purified by semipreparative RP-HPLC (0-20\% B + 0.1\% formic acid over $40 \mathrm{~min})$. The appropriate fractions were combined and lyophilized to afford 66 as a white solid $(10.3 \mathrm{mg}, 14 \%)$. UPLC: $R_{t}=4.48 \mathrm{~min}(0-50 \mathrm{vol} \% \mathrm{~B}$ over $5 \mathrm{~min}, 0.1$ vol $\%$ TFA, $\lambda=214 \mathrm{~nm}$ ). LRMS (ESI+): $\mathrm{m} / z=$ $1509.3[\mathrm{M}+\mathrm{H}]^{+}$. HRMS (ESI+): $m / z$ calcd for $\mathrm{C}_{66} \mathrm{H}_{102} \mathrm{~F}_{1} \mathrm{~N}_{23} \mathrm{O}_{15} \mathrm{~S}_{1}$ $[\mathrm{M}+3 \mathrm{H}]^{3+}$ 503.5950, found 503.5947.

Peptide (67) was synthesized via Fmoc-strategy SPPS as specified in general methods. The linear sequence $N^{\prime}$-(2Pal)LRFRPKDRGGC$C^{\prime}$ was generated by automated SPPS on the Rink amide resin (82 $\mathrm{mg}, 50 \mu \mathrm{mol}$, capacity: $0.52 \mathrm{mmolg}^{-1}$ ). Coupling of chloroacetic acid to the $\mathrm{N}$-terminus, cleavage from the resin, and cyclization were performed as described in the general methods. The crude cyclic peptide was purified by semipreparative RP-HPLC (0-20\% B + 0.1\% formic acid over $40 \mathrm{~min}$ ). The appropriate fractions were combined and lyophilized to afford 67 as a white solid (13.5 mg, 18\%). UPLC: $R_{t}=4.12 \mathrm{~min}(0-40$ vol $\% \mathrm{~B}$ over $5 \mathrm{~min}, 0.1 \mathrm{vol} \% \mathrm{TFA}, \lambda=214$ $\mathrm{nm})$. LRMS (ESI+): $m / z=1492.7[\mathrm{M}+\mathrm{H}]^{+}$. HRMS (ESI +$): m / z$ calcd for $\mathrm{C}_{65} \mathrm{H}_{102} \mathrm{~N}_{24} \mathrm{O}_{15} \mathrm{~S}_{1}[\mathrm{M}+3 \mathrm{H}]^{3+}$ 497.9299, found 497.9294.

Peptide (68) was synthesized via Fmoc-strategy SPPS as specified in general methods. The linear sequence $N^{\prime}$-(3Pal)LRFRPKDRGGC$C^{\prime}$ was generated by automated SPPS on the Rink amide resin $(82$ $\mathrm{mg}, 50 \mu \mathrm{mol}$, capacity: $0.52 \mathrm{mmolg}^{-1}$ ). Coupling of chloroacetic acid to the $\mathrm{N}$-terminus, cleavage from the resin, and cyclization were performed as described in the general methods. The crude cyclic peptide was purified by semipreparative RP-HPLC $(0-20 \%$ B $+0.1 \%$ formic acid over $40 \mathrm{~min}$ ). The appropriate fractions were combined and lyophilized to afford 68 as a white solid (12.5 mg, 16\%). UPLC:
$R_{t}=4.09 \mathrm{~min}(0-40 \mathrm{vol} \% \mathrm{~B}$ over $5 \mathrm{~min}, 0.1 \mathrm{vol} \% \mathrm{TFA}, \lambda=214$ nm). LRMS (ESI+): $m / z=1492.7[\mathrm{M}+\mathrm{H}]^{+}$. HRMS (ESI+): $m / z$ calcd for $\mathrm{C}_{65} \mathrm{H}_{102} \mathrm{~N}_{24} \mathrm{O}_{15} \mathrm{~S}_{1}[\mathrm{M}+3 \mathrm{H}]^{3+}$ 497.9299, found 497.9292.

Peptide (69) was synthesized via Fmoc-strategy SPPS as specified in general methods. The linear sequence $N^{\prime}$-(4Pal)LRFRPKDRGGC$C^{\prime}$ was generated by automated SPPS on the Rink amide resin (82 $\mathrm{mg}, 50 \mu \mathrm{mol}$, capacity: $0.52 \mathrm{mmolg}^{-1}$ ). Coupling of chloroacetic acid to the N-terminus, cleavage from the resin, and cyclization were performed as described in the general methods. The crude cyclic peptide was purified by semipreparative RP-HPLC $(0-20 \%$ B + 0.1\% formic acid over $40 \mathrm{~min}$ ). The appropriate fractions were combined and lyophilized to afford 69 as a white solid ( $8.7 \mathrm{mg}, 12 \%)$. UPLC: $R_{t}$ $=4.07 \mathrm{~min}(0-40 \mathrm{vol} \% \mathrm{~B}$ over $5 \mathrm{~min}, 0.1 \mathrm{vol} \%$ TFA, $\lambda=214 \mathrm{~nm})$. LRMS (ESI+): $m / z=1492.7[\mathrm{M}+\mathrm{H}]^{+}$. HRMS (ESI+): $m / z$ calcd for $\mathrm{C}_{65} \mathrm{H}_{102} \mathrm{~N}_{24} \mathrm{O}_{15} \mathrm{~S}_{1}[\mathrm{M}+3 \mathrm{H}]^{3+}$ 497.9299, found 497.9292.

Peptide (70) was synthesized via Fmoc-strategy SPPS as specified in general methods. The linear sequence $N^{\prime}$-(2MeOPhe)LRFRPKDRGGC- $C^{\prime}$ was generated by automated SPPS on the Rink amide resin $\left(82 \mathrm{mg}, 50 \mu \mathrm{mol}\right.$, capacity: $\left.0.52 \mathrm{mmolg}^{-1}\right)$. Coupling of chloroacetic acid to the $\mathrm{N}$-terminus, cleavage from the resin, and cyclization were performed as described in the general methods. The crude cyclic peptide was purified by semipreparative RP-HPLC (0-20\% B + 0.1\% formic acid over $40 \mathrm{~min})$. The appropriate fractions were combined and lyophilized to afford $\mathbf{7 0}$ as a white solid $(13 \mathrm{mg}, 13 \%) . R_{t}=4.67 \mathrm{~min}(0-50$ vol \% B over $5 \mathrm{~min}$, 0.1 vol \% TFA, $\lambda=214 \mathrm{~nm}$ ). LRMS (ESI +$): m / z=1521.5[\mathrm{M}+\mathrm{H}]^{+}$. HRMS (ESI+): $m / z$ calcd for $\mathrm{C}_{67} \mathrm{H}_{105} \mathrm{~N}_{23} \mathrm{O}_{16} \mathrm{~S}_{1}[\mathrm{M}+3 \mathrm{H}]^{3+}$ 507.6016, found 507.6010 .

Peptide (71) was synthesized via Fmoc-strategy SPPS as specified in general methods. The linear sequence $N^{\prime}$-(3MeOPhe)LRFRPKDRGGC- $C^{\prime}$ was generated by automated SPPS on the Rink amide resin $\left(82 \mathrm{mg}, 50 \mu \mathrm{mol}\right.$, capacity: $\left.0.52 \mathrm{mmolg}^{-1}\right)$. Coupling of chloroacetic acid to the $\mathrm{N}$-terminus, cleavage from the resin, and cyclization were performed as described in the general methods. The crude cyclic peptide was purified by semipreparative RP-HPLC (0-20\% B + 0.1\% formic acid over $40 \mathrm{~min})$. The appropriate fractions were combined and lyophilized to afford 71 as a white solid ( $12 \mathrm{mg}, 16 \%)$. UPLC: $R_{t}=4.52 \mathrm{~min}(0-50 \mathrm{vol} \% \mathrm{~B}$ over $5 \mathrm{~min}, 0.1 \mathrm{vol} \%$ TFA, $\lambda=214 \mathrm{~nm}$ ). LRMS (ESI+): $\mathrm{m} / z=1521.5[\mathrm{M}$ $+\mathrm{H}]^{+}$. HRMS (ESI $+: \mathrm{m} / z$ calcd for $\mathrm{C}_{67} \mathrm{H}_{105} \mathrm{~N}_{23} \mathrm{O}_{16} \mathrm{~S}_{1}[\mathrm{M}+3 \mathrm{H}]^{3+}$ 507.6016 , found 507.6011 .

Peptide (72) was synthesized via Fmoc-strategy SPPS as specified in general methods. The linear sequence $N^{\prime}$-(4MeOPhe)LRFRPKDRGGC- $C^{\prime}$ was generated by automated SPPS on the Rink amide resin $\left(82 \mathrm{mg}, 50 \mu \mathrm{mol}\right.$, capacity: $0.52 \mathrm{mmolg}^{-1}$ ). Coupling of chloroacetic acid to the $\mathrm{N}$-terminus, cleavage from the resin, and cyclization were performed as described in the general methods. The crude cyclic peptide was purified by semipreparative RP-HPLC (0-20\% B + 0.1\% formic acid over $40 \mathrm{~min}$ ). The appropriate fractions were combined and lyophilized to afford 72 as a white solid $(11.7 \mathrm{mg}, 15 \%)$. UPLC: $R_{t}=4.54 \mathrm{~min}(0-50$ vol \% B over $5 \mathrm{~min}, 0.1$ vol \% TFA, $\lambda=214 \mathrm{~nm}$ ). LRMS (ESI+): $\mathrm{m} / z=$ $1521.5[\mathrm{M}+\mathrm{H}]^{+}$. HRMS (ESI+): $m / z$ calcd for $\mathrm{C}_{67} \mathrm{H}_{105} \mathrm{~N}_{23} \mathrm{O}_{16} \mathrm{~S}_{1}[\mathrm{M}$ $+3 \mathrm{H}]^{3+} 507.6016$, found 507.6010 .

Peptide (73) was synthesized via Fmoc-strategy SPPS as specified in general methods. The linear sequence $N^{\prime}-\left(2 \mathrm{NO}_{2} \mathrm{Tyr}\right)$ LRFRPKDRGGC- $C^{\prime}$ was generated by automated SPPS on the Rink amide resin $\left(82 \mathrm{mg}, 50 \mu \mathrm{mol}\right.$, capacity: $\left.0.52 \mathrm{mmolg}^{-1}\right)$. Coupling of chloroacetic acid to the $\mathrm{N}$-terminus, cleavage from the resin, and cyclization were performed as described in the general methods. The crude cyclic peptide was purified by semipreparative RP-HPLC (0-20\% B + 0.1\% formic acid over $40 \mathrm{~min})$. The appropriate fractions were combined and lyophilized to afford 73 as a white solid $(13.3 \mathrm{mg}, 17 \%)$. UPLC: $R_{t}=4.40 \mathrm{~min}(0-50 \mathrm{vol} \% \mathrm{~B}$ over $5 \mathrm{~min}, 0.1$ vol \% TFA, $\lambda=214 \mathrm{~nm}$ ). LRMS (ESI+): $\mathrm{m} / z=$ $1552.8[\mathrm{M}+\mathrm{H}]^{+}$. HRMS (ESI+): $m / z$ calcd for $\mathrm{C}_{66} \mathrm{H}_{102} \mathrm{~N}_{24} \mathrm{O}_{18} \mathrm{~S}_{1}[\mathrm{M}$ $+3 \mathrm{H}]^{3+} 517.9248$, found 517.9249 .

Peptide (74) was synthesized via Fmoc-strategy SPPS as specified in general methods. The linear sequence $N^{\prime}$-(2FTyr)LRFRPKDRGGC- $C^{\prime}$ was generated by automated SPPS on the 
Rink amide resin $\left(82 \mathrm{mg}, 50 \mu \mathrm{mol}\right.$, capacity: $\left.0.52 \mathrm{mmolg}^{-1}\right)$. Coupling of chloroacetic acid to the $\mathrm{N}$-terminus, cleavage from the resin, and cyclization were performed as described in the general methods. The crude cyclic peptide was purified by semipreparative RP-HPLC (0-20\% B + 0.1\% formic acid over $40 \mathrm{~min}$ ). The appropriate fractions were combined and lyophilized to afford 74 as a white solid $(7.7 \mathrm{mg}, 10 \%)$. UPLC: $R_{t}=4.08 \mathrm{~min}(0-50 \mathrm{vol} \% \mathrm{~B}$ over $5 \mathrm{~min}, 0.1$ vol \% TFA, $\lambda=214 \mathrm{~nm}$ ). LRMS (ESI +$): m / z=1525.5[\mathrm{M}$ $+\mathrm{H}]^{+}$. HRMS (ESI+): $m / z$ calcd for $\mathrm{C}_{66} \mathrm{H}_{102} \mathrm{~F}_{1} \mathrm{~N}_{23} \mathrm{O}_{16} \mathrm{~S}_{1}[\mathrm{M}+3 \mathrm{H}]^{3+}$ 508.9266, found 508.9262 .

Peptide (75) was synthesized via Fmoc-strategy SPPS as specified in general methods. The linear sequence $N^{\prime}$-(hPhe)LRFRPKDRGGC- $C^{\prime}$ was generated by automated SPPS on the Rink amide resin $\left(82 \mathrm{mg}, 50 \mu \mathrm{mol}\right.$, capacity: $\left.0.52 \mathrm{mmolg}^{-1}\right)$. Coupling of chloroacetic acid to the $\mathrm{N}$-terminus, cleavage from the resin, and cyclization were performed as described in the general methods. The crude cyclic peptide was purified by semipreparative RP-HPLC (0-20\% B + 0.1\% formic acid over $40 \mathrm{~min})$. The appropriate fractions were combined and lyophilized to afford 75 as a white solid (7.4 mg, 10\%). UPLC: $R_{t}=4.59 \mathrm{~min}(0-50 \mathrm{vol} \% \mathrm{~B}$ over $5 \mathrm{~min}, 0.1$ vol \% TFA, $\lambda=214 \mathrm{~nm}$ ). LRMS (ESI +$): m / z=1505.5[\mathrm{M}$ $+\mathrm{H}]^{+}$. HRMS (ESI + ): $m / z$ calcd for $\mathrm{C}_{67} \mathrm{H}_{105} \mathrm{~N}_{23} \mathrm{O}_{16} \mathrm{~S}[\mathrm{M}+3 \mathrm{H}]^{3+}$ 502.2700, found 502.26931.

Peptide (76) was synthesized via Fmoc-strategy SPPS as specified in general methods. The linear sequence $N^{\prime}$-(hTyr)LRFRPKDRGGC- $C^{\prime}$ was generated by automated SPPS on the Rink amide resin $\left(82 \mathrm{mg}, 50 \mu \mathrm{mol}\right.$, capacity: $0.52 \mathrm{mmolg}^{-1}$ ). Coupling of chloroacetic acid to the $\mathrm{N}$-terminus, cleavage from the resin, and cyclization were performed as described in the general methods. The crude cyclic peptide was purified by semipreparative RP-HPLC (0-20\% B + 0.1\% formic acid over $40 \mathrm{~min})$. The appropriate fractions were combined and lyophilized to afford 76 as a white solid ( $5.1 \mathrm{mg}$, 7\%). UPLC: $R_{t}=4.10 \mathrm{~min}(0-50$ vol $\%$ B over 5 min, $0.1 \mathrm{vol} \%$ TFA, $\lambda=214 \mathrm{~nm}$ ). LRMS (ESI+): $m / z=1521.5[\mathrm{M}+$ $\mathrm{H}]^{+}$. HRMS (ESI+): $m / z$ calcd for $\mathrm{C}_{67} \mathrm{H}_{105} \mathrm{~N}_{23} \mathrm{O}_{16} \mathrm{~S}_{1}[\mathrm{M}+2 \mathrm{H}]^{2+}$ 760.8988 , found 760.8986 .

Peptide (77) was synthesized via Fmoc-strategy SPPS as specified in general methods. The linear sequence $N^{\prime}$-(Cha)LRFRPKDRGGC$C^{\prime}$ was generated by automated SPPS on the Rink amide resin (82 $\mathrm{mg}, 50 \mu \mathrm{mol}$, capacity: $0.52 \mathrm{mmolg}^{-1}$ ). Coupling of chloroacetic acid to the $\mathrm{N}$-terminus, cleavage from the resin, and cyclization were performed as described in the general methods. The crude cyclic peptide was purified by semipreparative RP-HPLC $(0-20 \%$ B + 0.1\% formic acid over $40 \mathrm{~min}$ ). The appropriate fractions were combined and lyophilized to afford 77 as a white solid $(7.7 \mathrm{mg}, 10 \%)$. UPLC: $R_{t}$ $=5.22 \mathrm{~min}(0-60 \mathrm{vol} \% \mathrm{~B}$ over $5 \mathrm{~min}, 0.1 \mathrm{vol} \%$ TFA, $\lambda=214 \mathrm{~nm})$. LRMS (ESI + ): $m / z=1497.3[\mathrm{M}+\mathrm{H}]^{+}$. HRMS (ESI+): $m / z$ calcd for $\mathrm{C}_{67} \mathrm{H}_{109} \mathrm{~N}_{23} \mathrm{O}_{15} \mathrm{~S}[\mathrm{M}+3 \mathrm{H}]^{3+} 499.6138$, found 499.6134 .

Peptide (78) was synthesized via Fmoc-strategy SPPS as specified in general methods. The linear sequence $N^{\prime}$-VLRFRPKDRGGC- $C^{\prime}$ was generated by automated SPPS on the Rink amide resin $(82 \mathrm{mg}$, $50 \mu \mathrm{mol}$, capacity: $0.52 \mathrm{mmolg}^{-1}$ ). Coupling of chloroacetic acid to the $\mathrm{N}$-terminus, cleavage from the resin, and cyclization were performed as described in the general methods. The crude cyclic peptide was purified by semipreparative RP-HPLC $(0-20 \% \mathrm{~B}+0.1 \%$ formic acid over $40 \mathrm{~min})$. The appropriate fractions were combined and lyophilized to afford 78 as a white solid $(12.4 \mathrm{mg}, 17 \%)$. UPLC: $R_{t}=4.60 \mathrm{~min}(0-40 \mathrm{vol} \% \mathrm{~B}$ over $5 \mathrm{~min}, 0.1 \mathrm{vol} \% \mathrm{TFA}, \lambda=214$ nm). LRMS (ESI+): $m / z=1443.3[\mathrm{M}+\mathrm{H}]^{+}$. HRMS (ESI+): $\mathrm{m} / z$ calcd for $\mathrm{C}_{62} \mathrm{H}_{103} \mathrm{~N}_{23} \mathrm{O}_{15} \mathrm{~S}_{1}[\mathrm{M}+2 \mathrm{H}]^{2+} 721.8935$, found 721.8932 .

Peptide (79) was synthesized via Fmoc-strategy SPPS as specified in general methods. The linear sequence $N^{\prime}$-PKDRGGC-C' $C^{\prime}$ was generated by automated SPPS on the Rink amide resin $(177 \mathrm{mg}$, $108.0 \mu \mathrm{mol}$, capacity: $0.57 \mathrm{mmolg}^{-1}$ ). Fmoc-DAB(Alloc)-OH was coupled in manually, an Alloc deprotection was performed, and the free amine was guanidinylated as described in the general procedures. Manual SPPS and coupling of chloroacetic acid were next undertaken to complete the linear sequence before the peptide was cleaved from the resin and cyclized; as per the general procedures, the crude cyclic peptide was purified by semipreparative RP-HPLC $(0-30 \%$ B + 0.1\% formic acid over $40 \mathrm{~min}$ ). The appropriate fractions were combined and lyophilized to afford 79 as a white solid $(8.1 \mathrm{mg}, 5 \%)$ UPLC: $R_{t}=$ $4.27 \mathrm{~min}(0-40$ vol \% B over $5 \mathrm{~min}, 0.1$ vol \% TFA, $\lambda=214 \mathrm{~nm})$. LRMS (ESI+): $m / z=1493.8[\mathrm{M}+\mathrm{H}]^{+}$. HRMS (ESI+): $m / z$ calcd for $\mathrm{C}_{65} \mathrm{H}_{101} \mathrm{~N}_{23} \mathrm{O}_{16} \mathrm{~S}[\mathrm{M}+3 \mathrm{H}]^{3+}$ 498.2579, found 498.2579.

Peptide (80) was synthesized via Fmoc-strategy SPPS as specified in general methods. The linear sequence $N^{\prime}$-PKDRGGC- $C^{\prime}$ was generated by automated SPPS on the Rink amide resin $(180 \mathrm{mg}$, $109.0 \mu \mathrm{mol}$, capacity: $0.57 \mathrm{mmolg}^{-1}$ ). Fmoc-Lys(Alloc)-OH was coupled in manually, an Alloc deprotection was performed, and the free amine was guanidinylated as described in the general procedures. Manual SPPS and coupling of chloroacetic acid were next undertaken to complete the linear sequence before the peptide was cleaved from resin and cyclized; as per the general procedures, the crude cyclic peptide was purified by semipreparative RP-HPLC $(0-30 \%$ B + 0.1\% formic acid over $40 \mathrm{~min})$. The appropriate fractions were combined and lyophilized to afford 80 as a white solid $(9.9 \mathrm{mg}, 6 \%)$. UPLC: $R_{t}$ $=4.16 \mathrm{~min}(0-50 \mathrm{vol} \% \mathrm{~B}$ over $5 \mathrm{~min}, 0.1 \mathrm{vol} \% \mathrm{TFA}, \lambda=214 \mathrm{~nm})$. LRMS (ESI+): $m / z=1521.5[\mathrm{M}+\mathrm{H}]^{+}$. HRMS (ESI+): $m / z$ calcd for $\mathrm{C}_{67} \mathrm{H}_{105} \mathrm{~N}_{23} \mathrm{O}_{16} \mathrm{~S}_{1}[\mathrm{M}+3 \mathrm{H}]^{3+} 507.6016$, found 507.6012.

Peptide (81) was synthesized via Fmoc-strategy SPPS as specified in general methods. The linear sequence $\mathrm{N}^{\prime}$-YLOFRPKDRGGC-C' was generated by automated SPPS on the Rink amide resin $(82 \mathrm{mg}$, $50 \mu \mathrm{mol}$, capacity: $0.56 \mathrm{mmolg}-1$ ). Coupling of chloroacetic acid to the $\mathrm{N}$-terminus, cleavage from the resin, and cyclization were performed as described in the general methods. The crude cyclic peptide was purified by semipreparative RP-HPLC (10-50\% B + $0.1 \%$ TFA acid over $45 \mathrm{~min}$ ). The appropriate fractions were combined and lyophilized to afford 81 as a white solid $(9.45 \mathrm{mg}$, $14 \%)$. UPLC: $R_{t}=3.78 \mathrm{~min}(0-60 \mathrm{vol} \% \mathrm{~B}$ over $5 \mathrm{~min}, 0.1 \mathrm{vol} \%$ TFA, $1=214 \mathrm{~nm}$ ). LRMS (ESI +$): m / z=1465.6$. HRMS (ESI +$): m / z$ calcd for $\mathrm{C}_{65} \mathrm{H}_{101} \mathrm{~N}_{21} \mathrm{O}_{16} \mathrm{~S}[\mathrm{M}+3 \mathrm{H}]^{3+} 488.9152$, found 488.9231 .

Peptide (82) was synthesized via Fmoc-strategy SPPS as specified in general methods. The linear sequence $N^{\prime}$-FRPKDRGGC- $C^{\prime}$ was generated by automated SPPS on the Rink amide resin $(180 \mathrm{mg}$, $109.0 \mu \mathrm{mol}$, capacity: $0.57 \mathrm{mmolg}^{-1}$ ). Fmoc-DAP(Alloc)-OH was coupled in manually, an Alloc deprotection was performed, and the free amine was guanidinylated as described in the general procedures. Manual SPPS and coupling of chloroacetic acid were next undertaken to complete the linear sequence before the peptide was cleaved from the resin and cyclized; as per the general procedures, the crude cyclic peptide was purified by semipreparative RP-HPLC $(0-30 \%$ B + $0.1 \%$ formic acid over $40 \mathrm{~min}$ ). The appropriate fractions were combined and lyophilized to afford 82 as a white solid $(9.4 \mathrm{mg}, 6 \%)$. UPLC: $R_{t}$ $=4.19 \min (0-50$ vol $\%$ B over $5 \mathrm{~min}, 0.1 \mathrm{vol} \%$ TFA, $\lambda=214 \mathrm{~nm})$. LRMS (ESI+): $m / z=1493.4[\mathrm{M}+\mathrm{H}]^{+}$. HRMS (ESI+): $\mathrm{m} / z$ calcd for $\mathrm{C}_{65} \mathrm{H}_{101} \mathrm{~N}_{23} \mathrm{O}_{16} \mathrm{~S}[\mathrm{M}+3 \mathrm{H}]^{3+} 498.2579$, found 498.2579.

Peptide (83) was synthesized via Fmoc-strategy SPPS as specified in general methods. The linear sequence $N^{\prime}$-PKDRGGC- $C^{\prime}$ was generated by automated SPPS on the Rink amide resin $(180 \mathrm{mg}$, $109.0 \mu \mathrm{mol}$, capacity: $0.57 \mathrm{mmolg}^{-1}$ ). Fmoc-Lys(Alloc)-OH was coupled in manually, an Alloc deprotection was performed, and the free amine was guanidinylated as described in the general procedures. Manual SPPS and coupling of chloroacetic acid were next undertaken to complete the linear sequence before the peptide was cleaved from the resin and cyclized; as per the general procedures, the crude cyclic peptide was purified by semipreparative RP-HPLC $(0-30 \%$ B $+0.1 \%$ formic acid over $40 \mathrm{~min}$ ). The appropriate fractions were combined and lyophilized to afford 83 as a white solid (11.6 mg, 7\%). UPLC: $R_{t}$ $=4.24 \mathrm{~min}(0-50 \mathrm{vol} \% \mathrm{~B}$ over $5 \mathrm{~min}, 0.1 \mathrm{vol} \%$ TFA, $\lambda=214 \mathrm{~nm})$. LRMS (ESI+): $m / z=1521.6[\mathrm{M}+\mathrm{H}]^{+}$. HRMS (ESI+): $m / z$ calcd for $\mathrm{C}_{67} \mathrm{H}_{105} \mathrm{~N}_{23} \mathrm{O}_{16} \mathrm{~S}[\mathrm{M}+3 \mathrm{H}]^{3+} 507.6016$, found 507.6012 .

Peptide (84) was synthesized via Fmoc-strategy SPPS as specified in general methods. The linear sequence $\mathrm{N}^{\prime}$-YLRFOPKDRGGC-C' was generated by automated SPPS on the Rink amide resin $(82 \mathrm{mg}$, $50 \mu \mathrm{mol}$, capacity: $0.51 \mathrm{mmolg}-1)$. Coupling of chloroacetic acid to the $\mathrm{N}$-terminus, cleavage from the resin, and cyclization were performed as described in the general methods. The crude cyclic peptide was purified by semipreparative RP-HPLC $(10-50 \%$ B + $0.1 \%$ TFA acid over $45 \mathrm{~min})$. The appropriate fractions were 
combined and lyophilized to afford 84 as a white solid (4.98 mg, $8 \%$ ). UPLC: $R_{t}=3.58 \mathrm{~min}(0-60$ vol $\%$ B over $5 \mathrm{~min}, 0.1$ vol \% TFA, $1=$ $214 \mathrm{~nm}$ ). LRMS (ESI+): $m / z=1465.5$. HRMS (ESI +$): m / z$ calcd for $\mathrm{C}_{65} \mathrm{H}_{100} \mathrm{~N}_{20} \mathrm{O}_{17} \mathrm{~S}[\mathrm{M}+2 \mathrm{H}]^{2+} 733.3648$, found 733.3819.

Peptide (85) was synthesized via Fmoc-strategy SPPS as specified in general methods. The linear sequence $\mathrm{N}^{\prime}$-YLKFRPKDRGGC- $\mathrm{C}^{\prime}$ was generated by automated SPPS on the Rink amide resin $(82 \mathrm{mg}$, $50 \mu \mathrm{mol}$, capacity: $0.56 \mathrm{mmolg}-1)$. Coupling of chloroacetic acid to the $\mathrm{N}$-terminus, cleavage from the resin, and cyclization were performed as described in the general methods. The crude cyclic peptide was purified by semipreparative RP-HPLC (10-50\% B + $0.1 \%$ TFA acid over $45 \mathrm{~min})$. The appropriate fractions were combined and lyophilized to afford 85 as a white solid $(6.13 \mathrm{mg}$, $15 \%)$. UPLC: $R_{t}=3.60 \mathrm{~min}(0-60 \mathrm{vol} \% \mathrm{~B}$ over $5 \mathrm{~min}, 0.1 \mathrm{vol} \%$ TFA, $l=214 \mathrm{~nm}$ ). LRMS (ESI +$): m / z=1479.6$. HRMS $($ ESI +$): m / z$ calcd for $\mathrm{C}_{66} \mathrm{H}_{103} \mathrm{~N}_{21} \mathrm{O}_{16} \mathrm{~S}[\mathrm{M}+3 \mathrm{H}]^{3+}$ 493.5871, found 493.5950.

Peptide (86) was synthesized via Fmoc-strategy SPPS as specified in general methods. The linear sequence $\mathrm{N}^{\prime}$-YLRFKPKDRGGC- $\mathrm{C}^{\prime}$ was generated by automated SPPS on the Rink amide resin $(82 \mathrm{mg}$, $50 \mu \mathrm{mol}$, capacity: $0.51 \mathrm{mmolg}-1$ ). Coupling of chloroacetic acid to the $\mathrm{N}$-terminus, cleavage from the resin, and cyclization were performed as described in the general methods. The crude cyclic peptide was purified by semipreparative RP-HPLC (10-50\% B + $0.1 \%$ TFA acid over $45 \mathrm{~min})$. The appropriate fractions were combined and lyophilized to afford 86 as a white solid $(7.47 \mathrm{mg}$, $11 \%)$. UPLC: $R_{t}=3.63 \mathrm{~min}(0-60 \mathrm{vol} \% \mathrm{~B}$ over $5 \mathrm{~min}, 0.1 \mathrm{vol} \%$ TFA, $1=214 \mathrm{~nm}$ ). LRMS (ESI+): $m / z=1479.5$. HRMS (ESI+) $: m / z$ calcd for $\mathrm{C}_{66} \mathrm{H}_{103} \mathrm{~N}_{21} \mathrm{O}_{16} \mathrm{~S}_{1}[\mathrm{M}+3 \mathrm{H}]^{3+}$ 493.5871, found 493.5950.

Assays of Human $\alpha$ FXIla Activity. The enzymatic activity of human $\alpha$ FXIIa (Enzyme Research Laboratories) was followed spectrophotometrically using H-D-Pro-Phe-Arg-p-nitroanilide (L2120, Bachem) as the chromogenic substrate. The assays were performed in $20 \mathrm{mM}$ HEPES pH 7.6, $150 \mathrm{mM} \mathrm{NaCl}, 0.1 \%(\mathrm{w} / \mathrm{v})$ PEG 8000, and $0.01 \%(\mathrm{v} / \mathrm{v})$ Triton X-100 with $4 \mathrm{nM}$ human $\alpha$ FXIIa, $200 \mu \mathrm{M}$ substrate, and varying concentrations of inhibitor $(0-100$ $\mu \mathrm{M})$. All reactions were initiated by the addition of the protease and carried out at $37^{\circ} \mathrm{C}$ in 96 -well flat-bottom microtiter plates. Reaction progress was monitored at $405 \mathrm{~nm}$ for $60 \mathrm{~min}$, with measurements taken every $5 \mathrm{~min}$ on a multimode microplate reader (Synergy2, Biotek). All measurements were performed in duplicate. $\mathrm{IC}_{50}$ values were determined with Prism 8 (GraphPad Software).

Assays of Human Flla, FXIa, and FXa Activities. The inhibition of the amidolytic activity of human FIIa (Haematologic Technologies) was followed spectrophotometrically using Tos-Gly-Pro-Arg-p-nitroanilide (Chromozym TH, Roche) as the chromogenic substrate. The assays were performed in $50 \mathrm{mM}$ Tris- $\mathrm{HCl} \mathrm{pH} 8.0,50 \mathrm{mM} \mathrm{NaCl}, 1$ mg mL ${ }^{-1}$ BSA with $0.2 \mathrm{nM}$ FIIa, $100 \mu \mathrm{M}$ substrate, and $33 \mu \mathrm{M}$ of a given inhibitor. All reactions were initiated by the addition of the protease, and measurements were recorded as for the FXIIa chromogenic assay.

The enzymatic activity FXIa or FXa (Haematologic Technologies) was determined in $25 \mathrm{mM}$ HEPES/MOPS sodium salt $\mathrm{pH} 7.5,100$ $\mathrm{mM} \mathrm{NaCl}, 5 \mathrm{mM} \mathrm{CaCl}$, and $1 \mathrm{mg} / \mathrm{mL}$ BSA with $0.5 \mathrm{nM}$ protease, $200 \mu \mathrm{M}$ fluorescent substrate SN45 or SN7 (Haematologic Technologies), and $33 \mu \mathrm{M}$ of a given inhibitor. All reactions were initiated by the addition of the protease and carried out at $37{ }^{\circ} \mathrm{C}$ in 96-well black flat-bottom microtiter plates. Fluorescence was recorded for $60 \mathrm{~min}$ with excitation and emission filters of $360 \pm 40$ and $460 \pm$ $40 \mathrm{~nm}$, respectively. The microplate reader (Synergy2, BioTek) was set up with Top400 configuration and a sensitivity of 35. Log-doseresponse curves for the inhibition of FXa were assayed in $25 \mathrm{mM}$ Tris$\mathrm{HCl} \mathrm{pH} \mathrm{7.5,} 100 \mathrm{mM} \mathrm{NaCl}, 5 \mathrm{mM} \mathrm{CaCl}$, and $1 \mathrm{mg} / \mathrm{mL}$ BSA with $0.5 \mathrm{nM}$ FXa, $500 \mu \mathrm{M}$ methoxycarbonyl-D-Nle-Gly-Arg-pNA (L-1565, Bachem), and varying concentrations of a given inhibitor (0-500 $\mu \mathrm{M})$. All reactions were initiated by the addition of the protease, and measurements were recorded and analyzed as for the FXIIa chromogenic assay.

Thrombin Generation. Thrombin generation was measured in normal pool plasma by means of the Calibrated Automated Thrombogram (CAT) method. Thrombin generation was continu- ously followed with fluorogenic substrate Z-GGR-AMC as described previously. ${ }^{38,41}$ Thrombin generation was determined at least in duplicate, and the lag-time, peak height, and endogenous thrombin potential (ETP) were calculated from averaged thrombin generation curves with CAT software provided by Thrombinoscope BV (Maastricht, The Netherlands). Normal pooled plasma from at least 80 healthy volunteers and factor XII-deficient plasma from a congenital deficient $(<1 \%$ FXII $)$ donor were both obtained in-house as described previously. ${ }^{42}$

$\mathrm{EC}_{50}$ values were derived from peak height data fitted to a doseresponse function (Graphpad 8.3.0).

Trigger via the Intrinsic Pathway. Normal pool plasma $(80 \mu \mathrm{L})$ was incubated for $5 \mathrm{~min}$ at $37{ }^{\circ} \mathrm{C}$ with ellagic acid $(53 \mathrm{nM}), 4 \mu \mathrm{M}$ phospholipid vesicles (20:60:20 DOPS/DOPC/DOPE, $\mathrm{mol} / \mathrm{mol} /$ $\mathrm{mol})$, and $0-8 \mu \mathrm{M}$ of a given FXIIa inhibitor. Coagulation was then initiated by the addition of $16 \mathrm{mM} \mathrm{CaCl}_{2}$ and $300 \mu \mathrm{M}$ Z-GGR-AMC (final concentrations in a total volume of $125 \mu \mathrm{L}$ ).

Trigger via the Extrinsic Pathway. Normal pool or FXII-deficient (George King Biomedical, Inc.) plasma $(80 \mu \mathrm{L})$ was incubated for 7 min at $37{ }^{\circ} \mathrm{C}$ in the presence of $0-8 \mu \mathrm{M}$ of a given FXIIa inhibitor. Next, tissue factor $(14 \mathrm{pM})$ and phospholipid vesicles $(4 \mu \mathrm{M}$, 20:60:20 DOPS/DOPC/DOPE, $\mathrm{mol} / \mathrm{mol} / \mathrm{mol}$ ) were added. Coagulation was then initiated by the addition of $16 \mathrm{mM} \mathrm{CaCl}_{2}$ and 300 $\mu \mathrm{M}$ Z-GGR-AMC (final concentrations in a total volume of $125 \mu \mathrm{L}$ ).

$a P T T / P T$. Prothrombin time (PT) and activated partial thromboplastin time (aPTT) assays were performed on a Siemens BCS XP system according to the manufacturer's instructions using Innovin and actin FS reagents, respectively.

Contact Activation of FXII and Detection of Bradykinin. Contact activation and detection of $\mathrm{BK}$ release assays were adapted from methods previously described. ${ }^{43}$ FXIIa inhibitor stocks were prepared by reconstituting in $100 \mathrm{vol} \%$ dimethyl sulfoxide (DMSO) to 200 $\mathrm{mM}$ and then diluting to $10 \mathrm{mM}$ with triple-distilled water. Pooled human plasma (Sigma P9523) was mixed in equal volumes with FXIIa inhibitors and diluted in HBS buffer (20 mM HEPES pH 7.5, 140 $\mathrm{mM} \mathrm{NaCl}$ ) to final concentrations of $1,10,100$, or $200 \mu \mathrm{M}$. After incubation for $10 \mathrm{~min}$ at $22{ }^{\circ} \mathrm{C}$, an equal volume of Kaolin solution (Sigma; $10 \mathrm{mg} \mathrm{mL}^{-1}$ in HBS buffer) was added and incubated for 15 min at $37{ }^{\circ} \mathrm{C}$ to activate plasma FXIIa. An equal volume of protease inhibitor cocktail ( $2 \times$ in triple-distilled water; Roche 05892791001 ) was added prior to determining the bradykinin concentration by ELISA, as per the manufacturer's instructions (Enzo ADI-900-206). The assays were performed in duplicate.

Ligand Docking and Molecular Dynamics Simulations. Ligand-Protein Complex Preparation. The bound FXIIa protein structure (PDB ID: 6L63 chain A) served as the template for manual docking with the ligand peptide 1 to obtain the starting configurations for molecular dynamics (MD) simulation studies. The initial positioning of the peptide was performed manually, based on the structure of Factor XIIa bound with the macrocyclic peptide F3.

Each structure was processed using the Protein Preparation Wizard in Maestro (Schrödinger Release2020-4: Protein Preparation Wizard; Epik, Schrödinger, LLC, New York, NY, 2016; Impact, Schrödinger, LLC, New York, NY, 2016; Prime, Schrödinger, LLC, New York, NY, 2020), which involved the assignment of bond orders, addition of hydrogens, creating disulfide bonds, filling missing loops and side chains using the Prime module, ${ }^{44}$ and generation of ionization states for the ligands at $\mathrm{pH} 7.0 \pm 2.0$ using Epik. Hydrogen-bond optimization was performed using the default parameters, and the protonation states of the residues were assigned using PROPKA at a $\mathrm{pH}$ of 7.0. Restrained minimization was performed (converging heavy atoms to RMSD $0.3 \AA$ ) using the OPLS $3 \mathrm{e}^{45}$ forcefield to obtain the final structures for MD studies.

Molecular Dynamics (MD). MD simulations were run using Desmond (Schrödinger Release2020-4, Desmond Molecular Dynamics System, DE Shaw Research, New York, NY, 2020). ${ }^{46}$ The Desmond System builder module was used to build the system, which involved enclosing the protein-ligand complex in an orthorhombic box with a buffer distance of $10 \AA$ using the Transferable Intermolecular Potential 3P (TIP3P) water model. The net charge 
of the system was then neutralized by the addition of counter ions $\left(\mathrm{Na}^{+}\right.$ions in this case), and $0.15 \mathrm{M} \mathrm{NaCl}$ was added. The OPLS3e forcefield was applied to the system. The system minimization was performed using the default parameters with a total simulation time of 100 ps.

The Molecular Dynamics module of Desmond was used to perform simulations of $300 \mathrm{~ns}$ duration in three replicates (using different initial seeds) for the Peptide 1-FXIIa complex. The isothermalisobaric (NPT) ensemble was chosen with an initial temperature and pressure of $300 \mathrm{~K}$ and $1.01325 \mathrm{bar}$, respectively. The time step was set to $2.0 \mathrm{fs}$, while the Nose-Hoover chain Langevin thermostat and the Martyna-Tobias-Klein barometer were selected to control the temperature and pressure, respectively, during the simulation. The cutoff method was chosen to determine the short-range Coulombic interactions, and the cutoff radius was set to $9 \AA^{41}$ After the completion of three simulations, the resultant trajectories (frames corresponding to every $0.3 \mathrm{~ns}$ ) were analyzed using the Simulation Event Analysis and the Simulation Interaction Diagram module of Desmond. ${ }^{42}$ For interaction analysis, the first 100 ns of each simulation was omitted and the remaining $200 \mathrm{~ns}$ of each of the three replicates were combined. The Trajectory Frame Clustering module of Desmond was used to generate representative structures from the combined trajectories. Clustering was performed based on all heavy atoms of the peptide ligand, with the frequency set to 10 and the maximum number of reported clusters set to 5 . The structure with the most frames among the reported clusters was chosen for the detailed binding interaction analysis. Structure figures were produced using PyMOL (The PyMOL Molecular Graphics System, Version 2.0 Schrödinger, LLC.).

\section{ASSOCIATED CONTENT}

\section{s) Supporting Information}

The Supporting Information is available free of charge at https://pubs.acs.org/doi/10.1021/acs.jmedchem.1c00651.

RaPID protocol, peptide sequences, oligonucleotide sequences, characterization data for peptides 1-86, synthetic methods for generating Nor-Arg- and homoArg-containing analogues, inhibitory data for 1-6 against FXIIa and a panel of proteases, additional thrombin generation data, plasma stability method, and data and supplementary figures for molecular dynamics simulations (PDF)

Molecular formula strings (excel) (CSV)

\section{AUTHOR INFORMATION}

\section{Corresponding Author}

Richard J. Payne - School of Chemistry, The University of Sydney, Sydney, New South Wales 2006, Australia; Australian Research Council Centre of Excellence for Innovations in Peptide and Protein Science, The University of Sydney, Sydney, New South Wales 2006, Australia; (1) orcid.org/0000-0002-3618-9226;

Email: richard.payne@sydney.edu.au

\section{Authors}

Daniel J. Ford - School of Chemistry, The University of Sydney, Sydney, New South Wales 2006, Australia; Australian Research Council Centre of Excellence for Innovations in Peptide and Protein Science, The University of Sydney, Sydney, New South Wales 2006, Australia

Nisharnthi M. Duggan - School of Chemistry, The University of Sydney, Sydney, New South Wales 2006, Australia; Australian Research Council Centre of Excellence for Innovations in Peptide and Protein Science, The University of Sydney, Sydney, New South Wales 2006, Australia
Sarah E. Fry - School of Chemistry, The University of Sydney, Sydney, New South Wales 2006, Australia; Australian Research Council Centre of Excellence for Innovations in Peptide and Protein Science, The University of Sydney, Sydney, New South Wales 2006, Australia

Jorge Ripoll-Rozada - IBMC - Instituto de Biologia Molecular e Celular, Universidade do Porto, 4200-135 Porto, Portugal; Instituto de Investigação e Inovação em Saúde, Universidade do Porto, 4200-135 Porto, Portugal; (1) orcid.org/0000-0001-7235-317X

Stijn M. Agten - Department of Biochemistry, University of Maastricht, Cardiovascular Research Institute Maastricht (CARIM), 6229 ER Maastricht, The Netherlands; (1) orcid.org/0000-0002-5973-272X

Wenyu Liu - Department of Chemistry, Graduate School of Science, The University of Tokyo, Tokyo 113-0033, Japan

Leo Corcilius - School of Chemistry, The University of Sydney, Sydney, New South Wales 2006, Australia; Australian Research Council Centre of Excellence for Innovations in Peptide and Protein Science, The University of Sydney, Sydney, New South Wales 2006, Australia

Tilman M. Hackeng - Department of Biochemistry, University of Maastricht, Cardiovascular Research Institute Maastricht (CARIM), 6229 ER Maastricht, The Netherlands

Rene van Oerle - Department of Biochemistry, University of Maastricht, Cardiovascular Research Institute Maastricht (CARIM), 6229 ER Maastricht, The Netherlands

Henri M. H. Spronk - Department of Biochemistry, University of Maastricht, Cardiovascular Research Institute Maastricht (CARIM), 6229 ER Maastricht, The Netherlands

Anneliese S. Ashhurst - School of Chemistry, The University of Sydney, Sydney, New South Wales 2006, Australia; Australian Research Council Centre of Excellence for Innovations in Peptide and Protein Science and Charles Perkins Centre, The University of Sydney, Sydney, New South Wales 2006, Australia; School of Medical Sciences, Faculty of Medicine and Health, Sydney, New South Wales 2006, Australia

Vishnu Mini Sasi - Australian Research Council Centre of Excellence for Innovations in Peptide and Protein Science, Australian National University, Canberra, ACT 0200, Australia; Research School of Chemistry, Australian National University, Canberra, ACT 0200, Australia

Joe A. Kaczmarski - Australian Research Council Centre of Excellence for Innovations in Peptide and Protein Science, Australian National University, Canberra, ACT 0200, Australia; Research School of Chemistry, Australian National University, Canberra, ACT 0200, Australia

Colin J. Jackson - Australian Research Council Centre of Excellence for Innovations in Peptide and Protein Science, Australian National University, Canberra, ACT 0200, Australia; Research School of Chemistry, Australian National University, Canberra, ACT 0200, Australia; 이이.org/ 0000-0001-6150-3822

Pedro José Barbosa Pereira - IBMC - Instituto de Biologia Molecular e Celular, Universidade do Porto, 4200-135 Porto, Portugal; Instituto de Investigação e Inovação em Saúde, Universidade do Porto, 4200-135 Porto, Portugal

Toby Passioura - School of Chemistry, The University of Sydney, Sydney, New South Wales 2006, Australia; Australian Research Council Centre of Excellence for 
Innovations in Peptide and Protein Science, The University of Sydney, Sydney, New South Wales 2006, Australia; Department of Chemistry, Graduate School of Science, The University of Tokyo, Tokyo 113-0033, Japan; School of Life and Environmental Sciences and Sydney Analytical, The University of Sydney, Sydney, NSW 2006, Australia; () orcid.org/0000-0002-6089-5067

Hiroaki Suga - Department of Chemistry, Graduate School of Science, The University of Tokyo, Tokyo 113-0033, Japan; ○ orcid.org/0000-0002-5298-9186

Complete contact information is available at:

https://pubs.acs.org/10.1021/acs.jmedchem.1c00651

\section{Author Contributions}

The manuscript was written through contributions of all authors. All authors have given approval to the final version of the manuscript.

\section{Notes}

The authors declare no competing financial interest.

\section{ACKNOWLEDGMENTS}

This work was funded by an NHMRC Investigator Grant (APP1174941 to R.J.P.). The authors also acknowledge support from the International Postgraduate Scholarship scheme (to D.F.), the Research Training Program scheme (to N.D.), and the John A. Lamberton Scholarship (to D.F.). This work was funded in part by a JSPS Grant-in-Aid for Specially Promoted Research (JP20H05681 to H.S.) and national funds through Fundação para a Ciência e a Tecnologia (Portugal) in the form of Contract DL 57/2016/ CP1355/CT0011 (to J.R.-R.) and a research grant PTDC/ BIA-BQM/2494/2020. The authors would like to thank Dr. Nicholas Proschogo for technical support with mass spectrometry, Dr. Cody Szczepina for technical support with HPLC, and Dr. Ian Luck and Dr. Wendy Tran for technical support with NMR spectroscopy.

\section{ABBREVIATIONS}

aPTT, activated partial thromboplastin time; BK, bradykinin; $B_{1} R, B_{1}$ receptor; $B_{2} R, B_{2}$ receptor; $B S A$, bovine serum albumin; CAT, calibrated automated thrombogram; C3a, complement component 3 subunit a; C5a, complement component 5 subunit a; C1qrs, complement component 1 subunit q, subunit $\mathrm{r}$, subunit s; CME, cyanomethyl ester; Cha, cyclohexylalanine; DIC, $N, N^{\prime}$-diisopropylcarbodiimide; ETP, endogenous thrombin potential; FIIa, factor IIa/thrombin; FXa, factor Xa; FXI, factor XI; FXII, Hageman factor/factor XII; FXIIa, factor XIIa; FA, formic acid; FIT, flexible in vitro translation; Fmoc-SPPS, Fmoc-strategy solid-phase peptide synthesis; GPVI, glycoprotein 6; HAE, hereditary angioedema; HEPES, (4-(2-hydroxyethyl)-1-piperazineethanesulfonic acid; HBS, HEPES-buffered saline; HMWK, high-molecular-weight kininogen; HKa, cleaved HMWK; hFXIIa, human FXIIa; KKS, kallikrein-kinin system; MOPS, 3-(N-morpholino)propanesulfonic acid; NPT, isothermal-isobaric; Oxyma, ethyl cyanohydroxyiminoacetate; OPLS3e, optimized potentials for liquid simulations 3e; PK, plasma kallikrein; PP NP, polyphosphate nanoparticles; PT, prothrombin time; RaPID, Randomised Nonstandard Peptide Integrated Discovery; RPHPLC, reversed-phase high-performance liquid chromatography; RT-PCR, reverse transcription-polymerase chain reaction; SPP, short polyphosphates; TF, tissue factor; TIP3, transferable intermolecular potential 3P; UPLC-MS, ultraperformance liquid chromatography-mass spectrometry; uPA, urokinase-type plasminogen activator

\section{REFERENCES}

(1) Renné, T.; Schmaier, A. H.; Nickel, K. F.; Blombäck, M.; Maas, C. In vivo roles of factor XII. Blood 2012, 120, 4296-4303.

(2) Davie, E. W.; Ratnoff, O. D. Waterfall sequence for intrinsic blood clotting. Science 1964, 145, 1310-1312.

(3) Macfarlane, R. An enzyme cascade in the blood clotting mechanism and its function as a biochemical amplifier. Nature 1964, 202, 498-499.

(4) Griffin, J. H.; Cochrane, C. G. [7] Human factor XII (Hageman factor). In Methods in Enzymology; Elsevier, 1976; Vol. 45, pp 56-65.

(5) Long, A. T.; Kenne, E.; Jung, R.; Fuchs, T. A.; Renné, T. Contact system revisited: an interface between inflammation, coagulation, and innate immunity. J. Thromb. Haemostasis 2016, 14, 427-437.

(6) Hall, J. M. Bradykinin receptors: pharmacological properties and biological roles. Pharmacol. Ther. 1992, 56, 131-190.

(7) Leeb-Lundberg, L. M. F.; Marceau, F.; Müller-Esterl, W.; Pettibone, D. J.; Zuraw, B. L. International union of pharmacology. XLV. Classification of the kinin receptor family: from molecular mechanisms to pathophysiological consequences. Pharmacol. Rev. 2005, 57, 27-77.

(8) Ghebrehiwet, B.; CebadaMora, C.; Tantral, L.; Jesty, J.; Peerschke, E. I. gC1qR/p33 serves as a molecular bridge between the complement and contact activation systems and is an important catalyst in inflammation. In Current Topics in Complement; Springer, 2006; pp 95-105.

(9) Larsson, M.; Rayzman, V.; Nolte, M. W.; Nickel, K. F.; Björkqvist, J.; Jämsä, A.; Hardy, M. P.; Fries, M.; Schmidbauer, S.; Hedenqvist, P.; et al. A factor XIIa inhibitory antibody provides thromboprotection in extracorporeal circulation without increasing bleeding risk. Sci. Transl. Med. 2014, 6, 222ra17.

(10) Renné, T.; Pozgajová, M.; Grüner, S.; et al. Defective thrombus formation in mice lacking coagulation factor XII. J. Exp. Med. 2005, 202, 271-281.

(11) Matafonov, A.; Leung, P. Y.; Gailani, A. E.; Grach, S. L.; Puy, C.; Cheng, Q.; Sun, M.-f.; McCarty, O. J.; Tucker, E. I.; Kataoka, H.; et al. Factor XII inhibition reduces thrombus formation in a primate thrombosis model. Blood 2014, 123, 1739-1746.

(12) Baeriswyl, V.; Calzavarini, S.; Chen, S.; Zorzi, A.; Bologna, L.; Angelillo-Scherrer, A.; Heinis, C. A synthetic factor XIIa inhibitor blocks selectively intrinsic coagulation initiation. ACS Chem. Biol. 2015, 10, 1861-1870.

(13) Baeriswyl, V.; Calzavarini, S.; Gerschheimer, C.; Diderich, P.; Angelillo-Scherrer, A.; Heinis, C. Development of a selective peptide macrocycle inhibitor of coagulation factor XII toward the generation of a safe antithrombotic therapy. J. Med. Chem. 2013, 56, 3742-3746.

(14) Bouckaert, C.; Zhu, S.; Govers-Riemslag, J. W.; Depoorter, M.; Diamond, S. L.; Pochet, L. Discovery and assessment of water soluble coumarins as inhibitors of the coagulation contact pathway. Thromb. Res. 2017, 157, 126-133.

(15) Cao, H.; Biondo, M.; Lioe, H.; Busfield, S.; Rayzman, V.; Nieswandt, B.; Bork, K.; Harrison, L. C.; Auyeung, P.; Farkas, H.; et al. Antibody-mediated inhibition of FXIIa blocks downstream bradykinin generation. J. Allergy Clin. Immunol. 2018, 142, 13551358.

(16) Dementiev, A.; Silva, A.; Yee, C.; Li, Z.; Flavin, M. T.; Sham, H.; Partridge, J. R. Structures of human plasma $\beta$-factor XIIa cocrystallized with potent inhibitors. Blood Adv. 2018, 2, 549-558.

(17) May, F.; Krupka, J.; Fries, M.; Thielmann, I.; Pragst, I.; Weimer, T.; Panousis, C.; Nieswandt, B.; Stoll, G.; Dickneite, G.; et al. FXII a inhibitor rHA-infestin-4: Safe thromboprotection in experimental venous, arterial and foreign surface-induced thrombosis. Br. J. Haematol. 2016, 173, 769-778.

(18) Middendorp, S. J.; Wilbs, J.; Quarroz, C.; Calzavarini, S.; Angelillo-Scherrer, A.; Heinis, C. Peptide macrocycle inhibitor of 
coagulation factor XII with subnanomolar affinity and high target selectivity. J. Med. Chem. 2017, 60, 1151-1158.

(19) Worm, M.; Köhler, E. C.; Panda, R.; Long, A.; Butler, L. M.; Stavrou, E. X.; Nickel, K. F.; Fuchs, T. A.; Renné, T. The factor XIIa blocking antibody 3F7: a safe anticoagulant with anti-inflammatory activities. Ann. Transl. Med. 2015, 3, 247.

(20) Wilbs, J.; Kong, X.-D.; Middendorp, S. J.; Prince, R.; Cooke, A.; Demarest, C. T.; Abdelhafez, M. M.; Roberts, K.; Umei, N.; Gonschorek, P.; Lamers, C.; Deyle, K.; Rieben, R.; Cook, K. E.; Angelillo-Scherrer, A.; Heinis, C. Cyclic peptide FXII inhibitor provides safe anticoagulation in a thrombosis model and in artificial lungs. Nat. Commun. 2020, 11, No. 3890.

(21) Zorzi, A.; Middendorp, S. J.; Wilbs, J.; Deyle, K.; Heinis, C. Acylated heptapeptide binds albumin with high affinity and application as tag furnishes long-acting peptides. Nat. Commun. 2017, 8, No. 16092.

(22) Shatzel, J.; DeLoughery, E.; Lorentz, C.; Tucker, E.; Aslan, J.; Hinds, M.; Gailani, D.; Weitz, J.; McCarty, O.; Gruber, A. The contact activation system as a potential therapeutic target in patients with COVID-19. Res. Pract. Thromb. Haemostasis 2020, 4, 500-505.

(23) Thachil, J.; Cushman, M.; Srivastava, A. A proposal for staging COVID-19 coagulopathy. Res. Pract. Thromb. Haemostasis 2020, 4, 731-736.

(24) Willyard, C. Coronavirus blood-clot mystery intensifies. Nature 2020, 581, 250.

(25) Vinogradov, A. A.; Yin, Y.; Suga, H. Macrocyclic peptides as drug candidates: Recent progress and remaining challenges. J. Am. Chem. Soc. 2019, 141, 4167-4181.

(26) Hipolito, C. J.; Suga, H. Ribosomal production and in vitro selection of natural product-like peptidomimetics: the FIT and RaPID systems. Curr. Opin. Chem. Biol. 2012, 16, 196-203.

(27) Passioura, T.; Katoh, T.; Goto, Y.; Suga, H. Selection-based discovery of druglike macrocyclic peptides. Annu. Rev. Biochem. 2014, 83, 727-752.

(28) Yamagishi, Y.; Shoji, I.; Miyagawa, S.; Kawakami, T.; Katoh, T.; Goto, Y.; Suga, H. Natural product-like macrocyclic N-methyl-peptide inhibitors against a ubiquitin ligase uncovered from a ribosomeexpressed de novo library. Chem. Biol. 2011, 18, 1562-1570.

(29) Deng, X.; Wang, L.; You, X.; Dai, P.; Zeng, Y. Advances in the T7 phage display system. Mol. Med. Rep. 2018, 17, 714-720.

(30) Johansen-Leete, J.; Passioura, T.; Foster, S. R.; Bhusal, R. P.; Ford, D. J.; Liu, M.; Jongkees, S. A.; Suga, H.; Stone, M. J.; Payne, R. J. Discovery of potent cyclic sulfopeptide chemokine inhibitors via reprogrammed genetic code mRNA display. J. Am. Chem. Soc. 2020, 142, 9141-9146.

(31) Patel, K.; Walport, L. J.; Walshe, J. L.; Solomon, P. D.; Low, J. K.; Tran, D. H.; Mouradian, K. S.; Silva, A. P.; Wilkinson-White, L.; Norman, A.; et al. Cyclic peptides can engage a single binding pocket through highly divergent modes. Proc. Natl. Acad. Sci. U.S.A. 2020, $117,26728-26738$.

(32) Kawamura, A.; Münzel, M.; Kojima, T.; Yapp, C.; Bhushan, B.; Goto, Y.; Tumber, A.; Katoh, T.; King, O. N.; Passioura, T.; Walport, L. J.; Hatch, S. B.; Madden, S.; Müller, S.; Brennan, P. E.; Chowdhury, R.; Hopkinson, R. J.; Suga, H.; Schofield, C. J. Highly selective inhibition of histone demethylases by de novo macrocyclic peptides. Nat. Commun. 2017, 8, No. 14773.

(33) Goto, Y.; Katoh, T.; Suga, H. Flexizymes for genetic code reprogramming. Nat. Protoc. 2011, 6, 779-790.

(34) Lovell, S. C.; Davis, I. W.; Arendall, W. B., III; De Bakker, P. I.; Word, J. M.; Prisant, M. G.; Richardson, J. S.; Richardson, D. C. Structure validation by $\mathrm{C} \alpha$ geometry: $\phi, \psi$ and $\mathrm{C} \beta$ deviation. Proteins 2003, 50, 437-450.

(35) Katoh, T.; Sengoku, T.; Hirata, K.; Ogata, K.; Suga, H. Ribosomal synthesis and de novo discovery of bioactive foldamer peptides containing cyclic $\beta$-amino acids. Nat. Chem. 2020, 12, 10811088.

(36) Pathak, M.; Manna, R.; Li, C.; Kaira, B. G.; Hamad, B. K.; Belviso, B. D.; Bonturi, C. R.; Dreveny, I.; Fischer, P. M.; Dekker, L. $\mathrm{V}$; i et al. Crystal structures of the recombinant $\beta$-factor XIIa protease with bound Thr-Arg and Pro-Arg substrate mimetics. Acta Crystallogr., Sect. D: Struct. Biol. 2019, 75, 578-591.

(37) Vlieghe, P.; Lisowski, V.; Martinez, J.; Khrestchatisky, M. Synthetic therapeutic peptides: science and market. Drug Discovery Today 2010, 15, 40-56.

(38) Hemker, H.; Giesen, P.; AlDieri, R.; Regnault, V.; De Smed, E.; Wagenvoord, R.; Lecompte, T.; Beguin, S. The calibrated automated thrombogram (CAT): a universal routine test for hyper-and hypocoagulability. Pathophysiol. Haemostasis Thromb. 2002, 32, 249-253.

(39) Rogers, J. M.; Passioura, T.; Suga, H. Nonproteinogenic deep mutational scanning of linear and cyclic peptides. Proc. Natl. Acad. Sci. U.S.A. 2018, 115, 10959-10964.

(40) Hayashi, Y.; Morimoto, J.; Suga, H. In vitro selection of antiAkt2 thioether-macrocyclic peptides leading to isoform-selective inhibitors. ACS Chem. Biol. 2012, 7, 607-613.

(41) Svetlana, N. T. c.; van Vliet, H. A.; Thomassen, M. C. L.; Bertina, R. M.; Rosendaal, F. R.; Sandset, P.-M.; Helmerhorst, F. M.; Tans, G.; Rosing, J. Effect of oral contraceptives on thrombin generation measured via calibrated automated thrombography. Thromb. Haemostasis 2007, 98, 1350-1356.

(42) Loeffen, R.; Kleinegris, M. C.; Loubele, S.; Pluijmen, P.; Fens, D.; Van Oerle, R.; Ten Cate, H.; Spronk, H. Preanalytic variables of thrombin generation: towards a standard procedure and validation of the method. J. Thromb. Haemostasis 2012, 10, 2544-2554.

(43) Teufel, D. P.; Bennett, G.; Harrison, H.; Van Rietschoten, K.; Pavan, S.; Stace, C.; Le Floch, F.; Van Bergen, T.; Vermassen, E.; Barbeaux, P.; Hu, T.-T.; Feyen, J. H. M.; Vanhove, M. Stable and long-lasting, novel bicyclic peptide plasma kallikrein inhibitors for the treatment of diabetic macular edema. J. Med. Chem. 2018, 61, 28232836.

(44) Jacobson, M. P.; Pincus, D. L.; Rapp, C. S.; Day, T. J.; Honig, B.; Shaw, D. E.; Friesner, R. A. A hierarchical approach to all-atom protein loop prediction. Proteins 2004, 55, 351-367.

(45) Roos, K.; Wu, C.; Damm, W.; Reboul, M.; Stevenson, J. M.; Lu, C.; Dahlgren, M. K.; Mondal, S.; Chen, W.; Wang, L.; et al. OPLS3e: Extending force field coverage for drug-like small molecules. J. Chem. Theory Comput. 2019, 15, 1863-1874.

(46) Bowers, K. J.; Chow, D. E.; Xu, H.; Dror, R. O.; Eastwood, M. P.; Gregersen, B. A.; Klepeis, J. L.; Kolossvary, I.; Moraes, M. A.; Sacerdoti, F. D. In Scalable algorithms for molecular dynamics simulations on commodity clusters; SC'06: Proceedings of the 2006 ACM/IEEE Conference on supercomputing, IEEE, 2006; p 43. 